\title{
SUBGENUS FISSIDENS IN TROPICAL EASTERN AFRICA WITH EMPHASIS ON THE TANZANIAN COLLECTIONS BY TAMÁS PÓCS
}

\author{
MARIA AlidA BRUgGEMAN-NANNENGA
}

\begin{abstract}
Illustrated revision of Fissidens subgenus Fissidens in tropical eastern Africa. Fissidens artsii Brugg.-Nann. is newly reported from Kenya, Tanzania and Uganda; F. gomae P. de la Varde \& J.-F. Leroy to Uganda and F. leucocinctus Hampe to Angola; F. magnicellulatus Brugg.-Nann., F. pachylomadelphus Demaret \& P. de la Varde, F. robynsianus P. de la Varde, F. rotereaui P. de la Varde and F. taylorii Müll. Hal. are new to Tanzania. The last is also new for Africa. The following taxonomic changes are proposed: Fissidens androgynus Bruch in Krauss (F. simensis Schimp. ex Müll. Hal., syn. nov., F. longipes Welw. \& Duby, syn. nov., F. subremotifolius Müll. Hal., syn. nov., F. gueinzii Müll. Hal., syn. nov., F. malaco-bryoides Müll. Hal., syn. nov., F. obsoletidens Müll. Hal. var. schistophila Broth., syn. nov., F. platybryoides Müll. Hal. var. subimmarginatus Dixon, syn. nov., F. crateris Dixon, syn. nov., F. crateris Dixon var. sererekae Dixon, syn. nov.), Fissidens crispus Mont. (F. hoeegii P. de la Varde syn. nov. and F. cataractarum Demaret \& P. de la Varde, syn. nov.). Reinstatements: F. pachylomadelphus Demaret \& P. de la Varde and F. rotereaui P. de la Varde (confirmed synonym Fissidens schelpei P. de la Varde).
\end{abstract}

Key words: Musci, Fissidens subgenus Fissidens, East Tropical Africa, Tanzania, taxonomy, distribution

Maria Alida Bruggeman-Nannenga, Griffensteijnseplein 23, NL 3703 BE Zeist, The Netherlands

\section{INTRODUCTION}

Tanzania, particularly the Eastern Arc Mountains, is one of the bryologically best known areas in tropical Africa. This is for a large part due to Dr. Tamás Pócs who has collected there for many years and attracted many colleagues to join him. The detailed data on his labels greatly augment our knowledge of the habitats and substrates preferred by each species. The present paper treats the East African species of Fissidens subgenus Fissidens. It is based mainly on the Tanzanian collections by Dr. Tamás Pócs since 1986. His earlier collections were treated by Bizot. Some Tanzanian collections by other bryologists notably Dr. Cliff Townsend are also included. Earlier collections of East African Fissidens have been treated in several publications. For example Bizot et al. (1976, 1978, 1979), Kis (1985), Bruggeman-Nannenga (1993, 1997, 1999, 2005, 2006a, b, 2009), BruggemanNannenga and Arts (2010), Bruggeman-Nannenga and Pursell (1995), O'Shea et al. (2001, 2003), O'Shea (2006) and Chuah-Petiot (2003). Kis (1985) listed all species then known from Southeast tropical Africa with references, distribution and where possible geographical details. O'Shea (2006) compiled a checklist of the mosses of subSaharan Africa with synonyms, distributions and references. Kis (1985) listed 30 subgenus Fissidens taxa from south-east tropical Africa including 24 from Tanzania. Since then several Fissidens species have been added to the Tanzanian Flora (Bruggeman-Nannenga 2009, 2013a, b) and a number of new synonyms have been proposed (Bruggeman-Nannenga 1993, 1997; BruggemanNannenga \& Pursell 1995; Shevock et al. (2013). As a result only 10 of the 24 species cited by Kis (1985) are maintained for the Tanzanian Flora, some under a different name. In addition 6 new Tanzanian indigenes, viz. F. artsii Brugg.-Nann. (also new to Kenya and Uganda), F. magnicellulatus Brugg.-Nann., F. pachylomadelphus Demaret \& P. de la Varde, F. robynsianus P. de la Varde, $F$. rotereaui $\mathrm{P}$. de la Varde and $F$. taylorii Müll. Hal. are reported. The last is new for Africa under this name. Two species in Kis' list, $F$. linearilimbatus Müll. Hal. and F. menyhartii Müll. Hal. are excluded because the types could not be located. 
The cosmopolitan subgenus Fissidens and subgenus Pachyfissidens sect. Pachyfissidens are relatively well represented in areas with a temperate climate and at high altitudes. Thus almost all European Fissidens species belong either to subgenus Fissidens or subgenus Pachyfissidens sect. Pachyfissidens, whereas only two European species ( $F$. exilis Hedw. and F. celticus Paton) belong in the mainly tropical subgenus Aloma. In tropical Eastern Africa subgenus Fissidens occurs from sea-level to $3870 \mathrm{~m}$. Above $2700 \mathrm{~m}$ it is both in species and number of specimens probably the best represented subgenus of Fissidens. Two species, $F$. artsii and F. acrophilus Brugg.-Nann., are restricted to high altitudes, whereas $F$. robynsianus seems to prefer them.

Most subgenus Fissidens species are mesophilous, hygrophilous or hydrophilous. The subgenus is found in a large variety of habitats. Four of the species included here ( $F$. leucocinctus, F. pachylomadelphus, $F$. robynsianus and $F$. obscurifrons Brugg.-Nann.) grow on rocks in rivers or in the spray of waterfalls or other places that are subject to occasional or frequent inundation. Most species grow on soil, rocks or wood. Some are occasionally found on termite mounds, but none of the species included in this paper is restricted to this habitat, nor is any one of them exclusively corticolous.

In tropical eastern Africa subgenus Fissidens is represented by 18 species. Four of these, viz. F. beckettii Mitt., F. crispus, F. curvatus and $F$. taylorii are pantropical. The remaining 14 species are African endemics. All but one, F. acrophilus Brugg.-Nann., of the species included in this paper are known from Tanzania.

\section{SOME MORPHOLOGICAL NOTES}

The adaxial (towards the stem) part of the Fissidens leaf consists of the vaginant and apical (ventral) lamina. The vaginant lamina consists of two lamellae that clasp the stem; the apical lamina is the simple part distal of the vaginant lamina; the abaxial dorsal lamina stretches from the leaf insertion to the leaf apex. The two lamellae of the vaginant lamina can be equal, subequal or unequal in size and shape. (Sub) equal lamellae are distally fused from costa to $( \pm)$ the margin. The vaginant lamina is then $( \pm)$ closed. Unequal lamellae are distally fused from the costa to some point on the lamina. When the lamellae are fused to a point closer to the margin than to the costa the vaginant lamina is slightly open; when the lamellae are fused to a point halfway between costa and margin the vaginant lamina is half open. When the smaller lamella ends at or near the costa the vaginant lamina is (completely) open. In most species the vaginant lamina is closed or slightly open. In F. beckettii, F. gladiolus Mitt., F. magnicellulatus, $F$. pygmaeus Hornsch. and F. rufescens Hornsch. it is open. When the vaginant lamina is open the distal part of the lesser lamella can be rounded (e.g., F. asplenioides Hedw.) or the smaller lamella can taper towards the costa and be acute to slightly rounded (see Fig. 4: 5-7).

\section{AXILLARY CELLS AND NODULES}

In some Fissidens species, notably those of subgenus Pachyfissidens sect. Crispidium, cortical stem cells in the leaf axils proliferate and form so-called large hyaline nodules (Iwatsuki \& Pursell 1980). In many species axillary cells have thinner and paler walls than other cortical cells. This is indicated as 'axillary cells differentiated' or, when such thin-walled cells protrude from the stem, as weak axillary nodules or slightly differentiated (see Fig. 6: 13).

\section{SOME PATTERNS OF VARIATION}

The aim of the following is to help the reader recognize some general patterns of variation found in Fissidens. Not recognizing these will result in 'comparing apples with oranges' and in finding false overlap between species.

\section{LEAVES}

Size and shape of the leaves vary along the stem. The leaves that develop first (the basal \pm 3 pairs of both fertile and vegetative stems) are smaller than and morphologically different from leaves that develop later. The latter (the so-called mid leaves) 
are similar in size and shape. In vegetative stems mid and upper leaves are similar. In the upper part of perichaetial stems the leaves gradually change culminating in the specialized, imbricate, long perichaetial leaves. Except in very short stems mid leaves of perichaetial stems are more or less similar to those of vegetative stems, though some influence of the perichaetium is often recognizable. For example upper and mid leaves of perichaetial stems often have better developed limbidia than mid leaves of vegetative stems. Another rule is that the degree of development of the limbidium decreases with the distance from the perichaetium. There are, however, a few species (e.g., F. robynsianus) in which there seems to be no relation between border development and distance from the perichaetium. In such species leaves with and without limbidium are arranged erratically along both vegetative and perichaetial stems.

It is important to appreciate these 'rules' when studying and comparing stems. In the present paper the term 'leaves' refers to mid and upper leaves of vegetative stems. When these were not available this is indicated. Some species are known from vegetative or from fertile stems only.

Leaves in subgenus Fissidens are typically unistratose, though bistratose stretches can occur particularly alongside the costa, in the corner between costa and upper vaginant lamina and near the insertion of the dorsal lamina (for instance in many hydrophilous species); small, unicellular bistratose dots in the mid apical and dorsal lamina are known from several species. These dots can be as deep as the lamina or protruding from it.

\section{STEMS}

Fissidens species have three kinds of stems. Perichaetial (sporophytic), perigonial and vegetative ones.

Perichaetial and vegetative stems

As discussed under 'leaves' the middle part of tall perichaetial stems differs very little from vegetative stems. However, short perichaetial stems with few leaf pairs have only morphological basal leaves and morphological upper and perichaetial leaves. Thus such short perichaetial stems are different from vegetative stems. This difference is enhanced when the perichaetial stems have close, frondose leaves and the vegetative stems distant, pinnate leaves. Short perichaetial stems that differ markedly from the pinnate vegetative stems are characteristic of a number of species. The best-known example probably is $F$. taxifolius Hedw. Another nice example is $F$. pygmaeus from southern Africa. Examples in the present paper are $F$. curvatus and $F$. taylorii. I indicate this condition as heterocaulous. This term is derived from section Heterocaulon (now subsumed under subgenus Fissidens) which was created by Müller (1900) for species in which vegetative stems differ more markedly from perichaetial stems than usual. There is no sharp distinction between heterocaulous and non heterocaulous species.

\section{Perigonial stems}

Perigonial stems and branches can be long or short. In many species they are very short and bud-shaped. Traditionally (and also in this paper), interest in perigonia is limited to their position: free, attached to the stem base of (perichaetial) stems, terminal or lateral and the morphology of perigonial leaves is ignored.

\section{LIMBIDIA}

Limbidia of the dorsal and apical lamina are marginal in nearly all species; limbidia of the vaginant laminae are frequently intramarginal on the mid and basal part.

\section{LAMINAL CELLS}

Vaginant laminal cells differ essentially from dorsal and apical laminal cells. In dorsal and apical laminal cells the walls are exposed on both sides of the leaf and may be plane, convex, smooth or papillose. Vaginant laminal cells on the other hand have an exposed abaxial and a sheltered adaxial wall. The exposed walls resemble those of dorsal and apical laminal cells and can be plane, convex, smooth or papillose; the adaxial walls are plane or slightly convex and always smooth. Furthermore, laminal cells are not homogeneous throughout 
a leaf. Inner dorsal and apical laminal cells are fairly similar, but nearness to the stem or the costa usually produces larger, more oblong cells with thicker, less ornamented walls. In species with narrow dorsal laminae, e.g. F. gladiolus, all inner cells are close to the costa. Marginal cells too tend to be morphologically different from inner cells. Similarly inner vaginant laminal cells often differ from inner dorsal and apical laminal cells. It is essential that only alike cells are compared. In my papers the term 'laminal cells' refers to inner dorsal laminal cells.

\section{Subgenus Fissidens section Fissidens}

For synonymy see Pursell and Bruggeman-Nannenga (2004).

Subgenus Fissidens is characterized by leaves that are limbate on all laminae, smooth, small to medium sized laminal cells and bryoides type costae. The sporophyte has a theca with 40 or more columns of exothecial and a bryoides type peristome (see below). The operculum typically has a short and blunt rostrum.

\section{VARIABILITY}

Subgenus Fissidens is gametophytically as well as sporophytically rather constant. Thus almost all species have limbidia on all laminae. In only a few species, for instance $F$. taylorii, F. rotereaui, $F$. bogosicus Müll. Hal. and F. obscurifrons in the present paper, the limbidium is or can be restricted to the vaginant lamina.

Species of subgenus Fissidens typically have a bryoides type costa which is characterized by 2 large adaxial and 1 or more large central cells (see Fig. 16: 8) and 1 row of 2 large cells distal of the vaginant lamina (see Fig. 10: 11). One of the included species, $F$. magnicellulatus, has anomalous costae, whereas $F$. megalotis Schimp. ex Müll. Hal. subsp. helictocaulos (Müll. Hal.) Brugg.-Nann. does have bryoides type costae, but these are asymmetrical. Fissidens pachylomadelphus has 1 row of 2-4 large cells distal of the vaginant lamina.

Laminal cells of subgenus Fissidens typically have plane or convex, smooth evenly thickened walls. In some species, however, e.g. F. megalotis subsp. helictocaulos, $F$. rufescens and $F$. artsii the cell walls are lenticularly thickened (see Fig. 3: 11 and 16: 10).

Further, this paper includes one species, $F$. gladiolus, in which the dorsal and apical lamina can be lacking. Such specimens lack the main characteristics of the family. However, the presence of dorsal and apical laminae in other specimens and the sporophyte make the position of $F$. gladiolus in subgenus Fissidens clear.

The sporophyte of subgenus Fissidens is rather constant in having a high number (40 or more) of columns of exothecial cells (found in all species in this paper) and a bryoides type peristome (see below). Only a few species (not in tropical east Africa) have anomalous peristomes. Confusion with subgenera other than Aloma is unlikely. In addition to gametophytic differences subgenus Fissidens and Aloma differ in their sporophytes. The subgenus Aloma sporophyte differs from the subgenus Fissidens sporophyte by the lower number $( \pm 32)$ of columns of exothecial files and the scariosus type of peristome (see below). Moreover, opercula in subg. Aloma often have longer and sharper rostra. So, differentiating between subgenus Fissidens and Aloma is usually easy. However, there are a few exceptions. For instance species with smooth laminal cells and limbidia restricted to the vaginant laminae are found in both subgenera. Furthermore, subgenus Aloma includes several species with limbate leaves and smooth laminal cells. Most of these are easily classified as subgenus Aloma by their large, inflated laminal cells as well as their Aloma type sporophyte. However, the gametophyte of one species, $F$. zollingeri Mont., looks deceptively like a subgenus Fissidens species as it has, except for the inflated vaginant laminal cells, smooth, medium sized cells and limbate leaves. Its sporophyte refers it to subgenus Aloma.

The bryoides - and scariosus type peristome differ in the exterior side of the basal undivided part and in the bifurcation of the teeth. The filaments are identical in both types. In the bryoides type the basal undivided part has trabeculae that are clearly distinct from and usually higher than the lamellae (see Fig. 2: 15), whereas in the scari- 
osus type trabeculae of the basal undivided part are indistinct or only slightly distinct from the \pm equally high to higher lamellae. The bifurcation of the bryoides type is variable. It has irregular trabeculae with coarse papillae and the vertical walls can be developed or not (see Fig. 2: 16, 17, and Fig. 11: 10); the bifurcation of the scariosus type on the other hand is constant with \pm smooth trabeculae that are continuous with the smooth vertical walls.

\section{KEY}

Unless stated differently both in the descriptions and in the key 'stem' refers to vegetative stems and 'leaves' to mid leaves of vegetative stems (see section on patterns of variation above). The term 'laminal cells' refers to the inner dorsal laminal cells of mid leaves of vegetative stems (see section on patterns of variation above).

1. Dorsal and apical laminae poorly developed or lacking, upper leaves subulate; vaginant laminae elimbate; inner vaginant laminal cells long and narrow ..... .................... 8. Fladiolus

1. Leaves with dorsal and apical laminae, upper leaves not subulate; vaginant laminae limbate; inner vaginant laminal cells wider (in one species long and narrow) $\ldots \ldots \ldots \ldots \ldots \ldots \ldots \ldots \ldots$

2. All leaves limbate on all laminae........6 6

2. Limbidia restricted to the vaginant laminae (some leaves with limbidia on the mid dorsal lamina sometimes present) . . . . . . . . . . 3

3. Costa percurrent; vaginant laminae of both vegetative and perichaetial stems limbate ... 16. F. rotereaui

3. Costa ending below the apex; extension limbidium various . . . . . . . . . . . . . . . 4

4. Distinctly heterocaulous, perichaetial plants small, frondose (Fig. 17: 4-6) and vegetative plants pinnate (Fig. 17: 3) . . . . . . . 18. F. taylorii

4. Not distinctly heterocaulous, perichaetial plants longer (Fig. 17: 2; Fig 5: 1-4 and 7) or unknown ..................... 5

5. Vaginant laminae of all leaves limbate, basal part of apical laminae often limbate; mid dorsal lamina infrequently weakly limbate.... 13. F. obscurifrons

5. Vaginant laminae of vegetative plants elimbate or with a few oblong marginal cells near the insertion .................... F. Fogosicus 6. Vaginant lamina nearly or completely open ... 7 6. Vaginant lamina closed to half open ...... 9
7. Mid dorsal laminal cells thick-walled and convex, 5-13 $\times 5-8 \mu \mathrm{m}$, leaves obscure with contrasting limbidia ............... 17. F. rufescens

7. Mid dorsal laminal cells thin-walled and plane, larger; leaves clear ................. 8

8. Mid dorsal laminal cells $9-25.5 \times 6-12 \mu \mathrm{m} \ldots$. 4. F. beckettii 8. Mid dorsal laminal cells $38.5-53 \times 8-11 \mu \mathrm{m} \ldots$ 11. F. magnicellulatus

9. Periodically submerged or rheophilous; basal part of dorsal lamina often pluristratose......... 10

9. In humid or dry, not aquatic habitats; basal part of dorsal lamina mostly unistratose. . . . . . . . . 14

10. Heterocaulous with short archegonial stems and branches ............ F. acrophilus $10^{*}$ Not distinctly heterocaulous . . . . . . . 11

11. Limbidia unistratose, ending below the leaf apices; basal parts of dorsal lamina unistratose ........ ..................... 9. Fomae

11. Limbidia pluristratose reaching the leaf apices or not; basal parts of dorsal lamina typically pluristratose

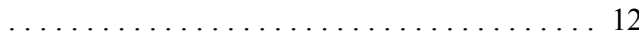

12. Limbidia ending well below the leaf apex . 13 $12^{*}$. Limbidia nearly or completely reaching the leaf apex ..........14. F. pachylomadelphus

13. Lower part of dorsal lamina often limbidioid (Fig. 14: $10,11) \ldots \ldots \ldots \ldots \ldots \ldots \ldots \ldots$. F robynsianus

13. Lower part of dorsal lamina not limbidioid ...... 10. F. leucocinctus

14. Theca with \pm 32 columns of exothecial cells . . ........... F. zollingeri (subg. Aloma)

14. Theca with 40 or more columns of exothecial cells ...................... 15

15. Laminal cells strongly convex, small (up to $9.5 \mu \mathrm{m}$ long); leaves obscure. . . . . . . . . . 16

$15^{*}$ Laminal cells plane or lowly convex, larger (up to $17.5 \mu \mathrm{m}$ ); leaves clear . . . . . . . . . . 18

16. Vaginant lamina slightly open; limbidia of the lamellae not confluent at the apex......... . . . . . 12. F. megalotis subsp. helictocaulos 16. Vaginant lamina closed in all or most leaves; limbidia of the lamellae confluent at the apex ....................... 17

17. Dorsal lamina frequently ending well above the insertion; leaf apex often hyaline..... 3. F. artsii

17 . Dorsal lamina reaching the insertion often long decurrent; leaf apex not hyaline ....6. 6. F. crispus 18. Heterocaulous . . . . . . . . . 7. F. curvatus 18 . Not distinctly heterocaulous ......... 19 
19. Limbidia delicate, unistratose, ending below the apex, not reaching the insertion of the dorsal laminae .................... 9. Fomae

19*. Limbidia stout, $1-3$ stratose, $( \pm)$ reaching the apex, reaching the insertion 2. F. androgynus

\section{DESCRIPTIONS OF THE SPECIES}

In a few cases it was impossible to make trans sections because of the paucity of material. This is indicated. Gemmae are only mentioned if they were observed.

Unless indicated differently all Tanzanian collections examined are cited. For some species a few additional collections from other countries are listed. The specimens are arranged by region. Citations of specimens are concise. Data on ecology and altitudes are omitted and summarized in the sections on habit, substrate and altitude. Descriptions of substrates and habitats are typically based on Tanzanian material.

The lists of synonyms in this paper are not complete. More synonyms can be found in O'Shea (2006) and in http://www.tropicos.org.

\section{Fissidens acrophilus Brugg.-Nann.}

Fig. 1

Polish Bot. J. 58(1): 117, fig. 1. 2013. - TYPE: Kenya, Mount Elgon National Park, at the Suam River sources $1 \mathrm{~km}$ WSW of Koitoboss summit. Carex runssorensisAlchemilla bog, on peaty soil. 3960 m. 17 January 1992. Kungu 9222/AD (HOLOTYPE: L; ISOTYPE: EGR).

MisapPliEd NAME: Fissidens anguste-limbatus Mitt. (Bruggeman-Nannenga 2009).

Growing in mats; stems heterocaulous, with central strand; rhizoids basal and frequently axillary, brown, smooth; axillary nodules weakly differentiated; perichaetial stems shorter than vegetative stems; vegetative stems branched or not, $8.0-10.0 \times 2.0-2.5 \mathrm{~mm}$, pinnate; leaves pale green, older leaves often with dark costa and limbidia, distant to partly overlapping, up to 20 pairs, hardly crispate when dry, broadly lanceolate, acute-acuminate to acute-mucronate, 1.10-1.30 $\times$ 0.40-0.45 mm, L/W 3, limbate; limbidium \pm reaching the leaf apex, confluent or not; confluent at the apex of the vaginant lamina, reaching the insertion of the vaginant lamina; reaching the insertion of the dorsal lamina, becoming indistinct on the decurrent part, in mid of dorsal lamina $24 \mu \mathrm{m}$ wide, $1-2$ stratose; on vaginant laminae 1-2 stratose, marginal; vaginant lamina $4 / 5$ the leaf length, slightly open to closed, unistratose; dorsal lamina narrow, slightly rounded at base, reaching the insertion, often slightly decurrent, dorsal and apical laminae unistratose; costa perto excurrent; mid dorsal laminal cells hexagonal, plane to slightly convex, $10.0-19.0 \times 7.0-11.5 \mu \mathrm{m}$, smooth; mid vaginant laminal cells $10.0-20.5 \times$ 5.0-11.0 $\mu \mathrm{m}$.

Fertile parts. Cladautoicous, perigonia terminal on short, axillary branches, budlike or slender, 0.3-0.7 mm long, antheridia $200 \mu \mathrm{m}$ long; perichaetia terminal on short stems and short branches; perichaetial stems 2-3 $\times 1 \mathrm{~mm}$, unbranched, frondiform, in clusters at the base of vegetative stems; leaves crowded, up to 5 pairs, perichaetial leaves up to $1.7 \mathrm{~mm}$ long; archegonia $\pm 300 \mu \mathrm{m}$ long; sporophyte, seta $6 \mathrm{~mm}$ long, smooth; capsule symmetrical to slightly oblique, $0.7-0.9 \times 0.5 \mathrm{~mm}$, \pm 64 columns of oblong exothecial cells; peristome bryoides type, teeth $45.0-49.5 \mu \mathrm{m}$ wide at base, short, $250 \mu \mathrm{m}$ long; operculum $0.45 \mathrm{~mm}$ long; $\mathrm{ca}$ lyptra not seen; spores subglobose, 16.5-19.5 $\mu \mathrm{m}$, coarsely papillose, green.

This species is characterized by its pale green, limbate, slightly decurrent, broadly lanceolate, acute-acuminate to acute-mucronate leaves with per- to excurrent costae and large, 10.0-19.0 $\times 7.0$ $11.5 \mu \mathrm{m}$, laminal cells; it has long, pinnate stems with basal clusters of short, frondiform perichaetial stems, short, axillary perichaetial and perigonial branches and short peristome teeth. Variability:

Fig. 1. Fissidens acrophilus Brugg.-Nann. 1 - vegetative stem $(2 \times) ; 2$ - sporophytic stem; 3 - perichaetial stem; 4 - perigonial branch; $5 \& 6$ - leaves; $7 \& 8$ - perichaetial leaves, $9 \& 10$ - leaf apices, 11 - mid leaf, 12 \& 13 - leaves near insertion; 14 weak axillary nodule. 1-3, 5-9, 11, 12 \& 14 from Kungu 9222/AD (holotype L); 4, 10 \& 13 from Wesche 9085 (private herbarium Bruggeman-Nannenga). 1-3, 5-12 \&14 were also used in the protologue). 

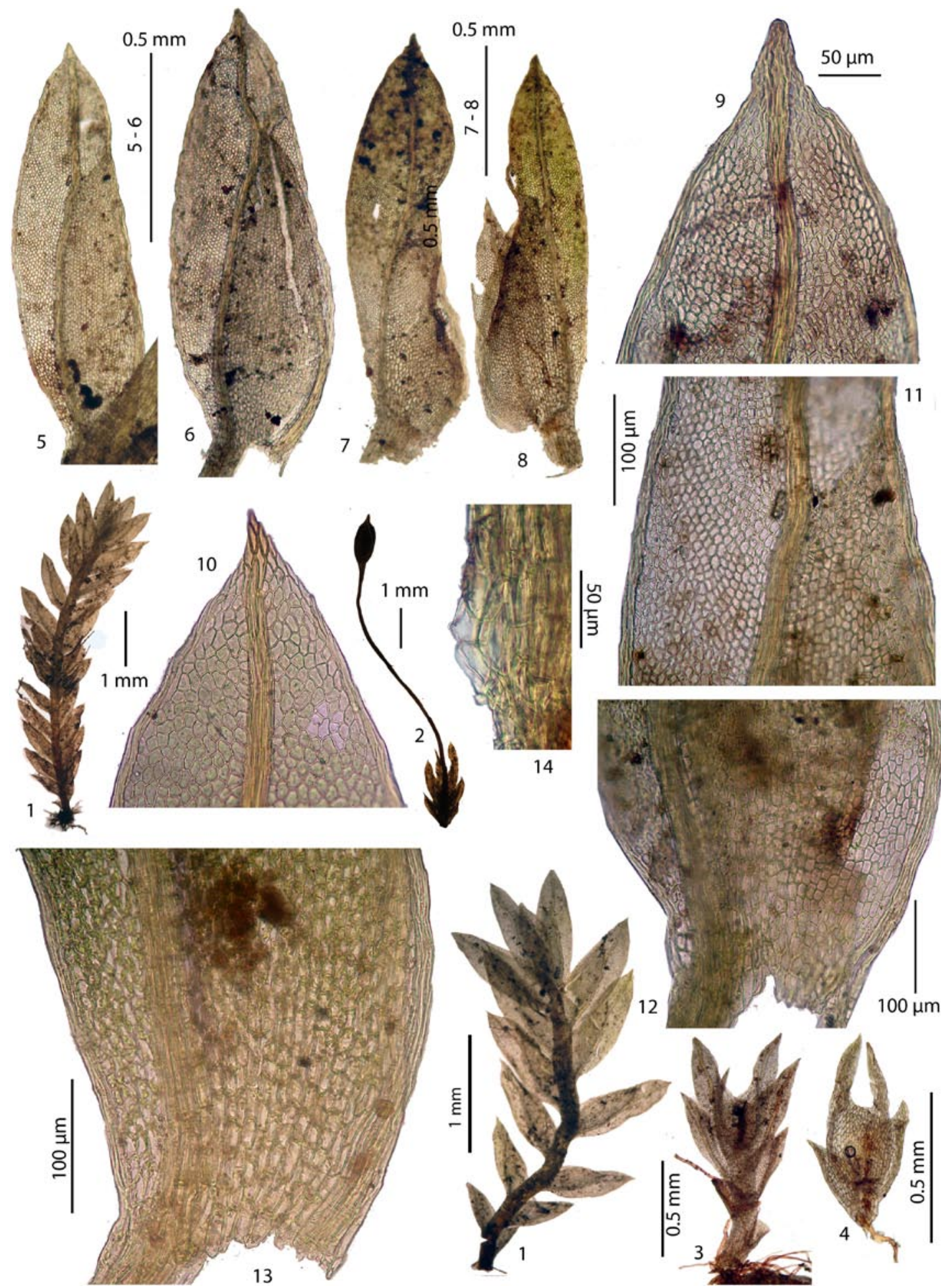
the type specimen differs from the other collection in the relatively long vaginant laminae. Fissidens acrophilus can be confused with large expressions of $F$. curvatus. This species can be distinguished by its limbidia that are confluent at the apex and its narrower, stiff vegetative leaves with dorsal laminae that are not decurrent. Fissidens androgynus can be separated by its terminal antheridia and archegonia. Moreover, it is not heterocaulous.

SUBSTRATE. On peaty soil, wet rocks.

HABITAT. Carex runssorensis-Alchemilla bog; afro-alpine zone unspecified.

Altitude. 3250-3960 m.

Distribution. Known only from Mt. Elgon (Kenya and Uganda).

SPECIMENS EXAMINED: KENYA, Mount Elgon National Park, Kungu 9222/AD (holotype: L; isotype: EGR). - UGANDA, Mt. Elgon, Wesche 9085 (private herbarium Bruggeman-Nannenga).

\section{Fissidens androgynus Bruch in Krauss}

Fig. 2

Flora 29: 134. 1846. - LECTOTYPE (designated by Magill 1981): South Africa, Natal auf dem Cape. An Bächen an der Küste. VII 1838. Krauss s.n. (BM).

Fissidens simensis Schimp. ex Müll. Hal., Bot. Zeitung (Berlin) 22: 341. 1864. - TYPE: Ethiopia, Mons Bachit, Schimper s.n. (HOLOTYPE: BM, ISOTYPE: PC) - syn. nov.

Fissidens longipes Welw. \& Duby, Mém. Soc. Phys. Genève 21: 224, tab. 4, fig. 3a-e. 1872. - TYPE: Welwitsch, iter Angolense 69 (ISOTYPES: BM, H-SOL) - syn. nov.

Fissidens subremotifolius Müll. Hal., Hedwigia 38: 54. 1899. - HoLOTYPE: South Africa, Transvaal, Lydenburg, Apr. 1887, Wilms s.n., herb. Jack (G) - syn. nov.

Fissidens gueinzii Müll. Hal., Linnaea 37: 168. 1872.
- LECTOTYPE (designated by Magill 1981): South Africa, Cape, Gueinzius s.n. (BM) - syn. nov.

Fissidens malaco-bryoides Müll. Hal., Hedwigia 38: 55. 1899. - TYPE: South Africa, Cape, Somerset East, Boschberg, Mac Owan s.n. (LECTOTYPE designated by Magill 1981: G; ISOLECTOTYPES as Rabenhorst-Winter Bryoth. Eur. 1365: H-BR, S) - syn. nov.

Fissidens obsoletidens Müll. Hal. var. schistophila Broth., Wiss. Ergebn. Deut. Zentr.-Afr. Exped., Bot. 2: 143. 1910. - HolotyPE: Rwanda [Afr. or., Ruanda], Buganza, trockene Wasserrinne in einer Schlucht der Bergsteppe auf Tonschiefer, $1600 \mathrm{~m}$, Mildbraed 800 (H-BR as var. schisticola) - syn. nov.

Fissidens platybryoides Müll. Hal. var. subimmarginatus Dixon, Bull. Soc. Roy. Bot. Belgique 60: 13. 1927. - TYPE: Democratic Republic of the Congo [Congo], steppe à Andropogon, sur pierre calcaire, 24 IX 1914, c. fr., Bequart 5857 (LECTOTYPE designated by Bruggeman-Nannenga 1993: BM as Bequart 438; ISOLECTOTYPE: PC as Bequart 438). NOTE: according to the protologue the number of the type specimen is 5857 . The specimen in Dixon's herbarium (BM), however, is Bequart 438 - syn. nov.

Fissidens crateris Dixon, J. Bot. 76: 219. 1938. - HoloTYPE: Kenya [Brit. East Africa], Crater of Mt. Longonot, Dummer 5049B (BM) - syn. nov.

Fissidens crateris Dixon var. sererekae Dixon, J. Bot. 76: 220. 1938. - HolotYPE: Kenya [Kenya Colony], Serereka, 29 I 1908, Balbo 63 (BM) - syn. nov.

Note. Except for Fissidens obsoletidens Müll. Hal. var. schistophila Broth. the above new synonyms were earlier synonymized with $F$. bryoides by Magill (1981) or F. bryoides s.l. by me (Bruggeman-Nannenga 1993).

MisAPPLIED NAME: Fissidens bryoides Hedw. (Magill 1981; Bruggeman-Nannenga 1993).

Growing in mats or scattered between other mosses. Stem with central strand, branched or not, 3-10 × 1-2 mm, pinnate; rhizoids basal and axillary, bright brown to red, smooth; axillary nodules

Fig. 2. Fissidens androgynus Bruch in Krauss 1 - short perichaetial stem; 2 - vegetative stem; 3-perigonial stem; 4-7 - leaves; 8-10 - leaf apices; 11 - mid leaf; 12 - basal part of leaf; 13 - capsule; 14 - operculum; 15 - undivided, basal part peristome; $16 \& 17$ - peristome teeth at bifurcation. 1 from Pócs 88086/D (private herbarium Bruggeman-Nannenga); 2,3 \& 7 from Pócs 8664/E (L); 4 \& 6 from Gilbert 8477 (L); 5 from Pócs et al. 90021/AG (EGR, private herbarium Bruggeman-Nannenga); 8, 11 \&12 from Pócs \& Chuwa 89025/W (private herbarium Bruggeman-Nannenga); 10 from Townsend 77/340 (E); 9 \& 15 from Kiss \& Pócs 9112 /AM (L); 13, 14, 16 \& 17 from Van Zanten \& Pócs 86.07.228 W (private herbarium Bruggeman-Nannenga). The brown coloring in $8,11 \& 12$ is caused by $5 \% \mathrm{KOH}$. 


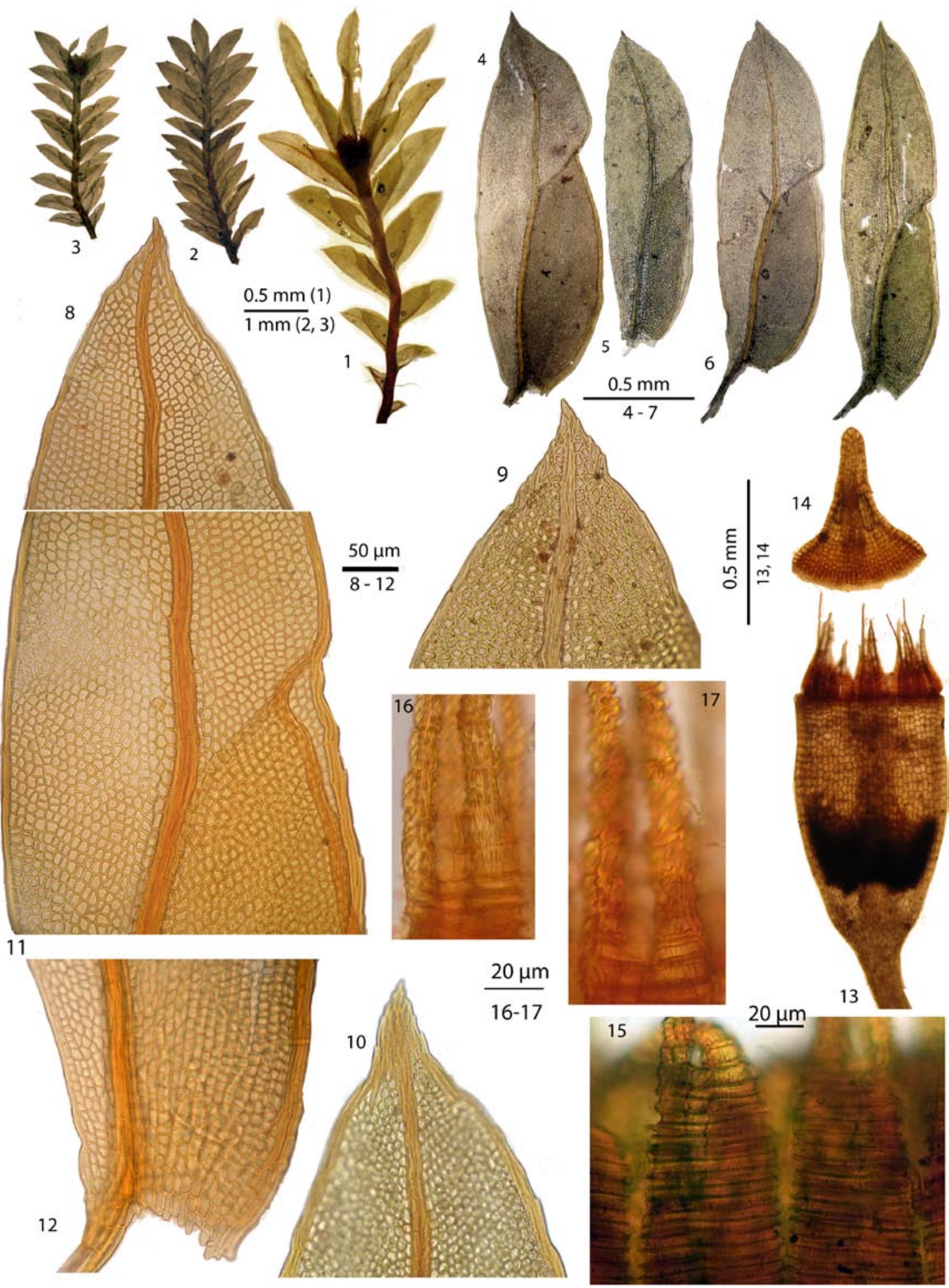


lacking or weakly differentiated; leaves green, becoming brown in $5 \% \mathrm{KOH}$, costa and limbidium often brown in older specimens, close to distant, 10-21 pairs, crispate when dry, elliptical, oblonglanceolate, broadly acute to obtuse, acuminatemucronate to mucronate, $1.0-1.7 \times 0.3-0.5 \mathrm{~mm}$, L/W 2.75-5.00, limbate; limbidium reaching or \pm reaching the leaf apex; reaching the insertion of the vaginant lamina, confluent at the apex of the vaginant lamina; reaching the insertion of the dorsal laminae, on decurrent part of dorsal lamina not or poorly developed; on mid dorsal lamina 8-16 $\mu \mathrm{m}$ wide, 1-3 stratose; on the vaginant lamina 1-2 stratose, marginal throughout or intramarginal by 1 row of cells near the insertion of the vaginant laminae; vaginant lamina 1/2-7/10 leaf length, closed, unistratose; dorsal lamina slightly rounded to straight at the insertion, slightly undulate or not, reaching the insertion, not to long decurrent, dorsal and apical laminae unistratose occasionally with some small bistratose areas; costa per- to excurrent; mid dorsal laminal cells hexagonal-oblong, plane to slightly convex, smooth, 8.0-16.0 $\times 5.0-11.0 \mu \mathrm{m}$, walls firm; mid vaginant laminal cells $9.5-16.0 \times 5.0-8.0 \mu \mathrm{m}$.

Fertile parts, synoicia infrequent, terminal; perigonia terminal on $1.5-8.0 \mathrm{~mm}$ long stems or on branches of perichaetial, perigonial or vegetative stems; antheridia 200-400 $\mu \mathrm{m}$ long; perichaetia terminal; perichaetial leaves often considerably longer than stem leaves (to about twice as long), 1.2-2.3 mm long; archegonia 300-500 $\mu \mathrm{m}$ long; sporophyte, seta 4.5-8.0 mm long, 1-2 per perichaetium, smooth; capsule $( \pm)$ symmetrical, $0.5-1.1 \times 0.35-0.60 \mathrm{~mm}, 56-60$ columns of oblong exothecial cells; peristome bryoides type, tooth base 35-65 $\mu \mathrm{m}$ wide; operculum $0.4-0.5 \mathrm{~mm}$ long with short, blunt rostrum; calyptra mitrate, smooth, 0.65-0.70 mm long; spores subglobose, 9.5-18.0 $\mu \mathrm{m}$ long, smooth to finely papillose.

This common, variable species is characterized by its rather large size, clear, 8.0-16.0 × 5.0$11.0 \mu \mathrm{m}$, plane to slightly convex laminal cells; limbidia that reach or \pm reach the leaf apex; and antheridia terminal on $1.5-8.0 \mathrm{~mm}$ tall perigonial stems or on branches. Fissidens androgynus is most likely to be confused with the pantropical $F$. crispus Mont. with which it often grows mixed. Fissidens crispus has uniform, small, quadratic, convex cells arranged in rows whereas $F$. androgynus has larger, less uniform, plane to slightly convex cells. At low magnifications $F$. crispus can usually be distinguished by its obscure leaves (see Fig. 6: 5-7). However, these diagnostic characters are not rigidly linked and not all collections can be identified with certainty. Particularly specimens with small cells arranged in rows that are not or hardly convex are hard to name. Moreover, in both species the dorsal laminae can end at the insertion or be long decurrent and the limbidia can be marginal or intramarginal. Specimens of $F$. androgynus with stout borders and mucronate leaf tips can be confused with $F$. pachylomadelphus. This species is distinguished by its rheophilous habitat, dorsal laminae that are $1-4$ stratose near the insertion and thick limbidia (3-4 stratose on the mid dorsal lamina). Fissidens gomae P. de la Varde \& J.-F. Leroy has more delicate, unistratose limbidia that end below the apex. Fissidens bryoides Hedw. (not known from Sub-Saharan Africa) typically has axillary perigonial buds. Axillary perigonial buds are not known in F. androgynus.

HABITAT. This species is known from a wide variety of wet to rather dry forests. For example, in Cupressus lusitanica plantation forests $(10 \times)$, elfin forests $(1 \times)$, montane rainforests $(4 \times)$, submontane rainforests $(1 \times)$, riverine forests $(2 \times)$, mossy to dry evergreen forests etc.; once in Ericaceae belt just above the forest line; also known from stream and road banks.

SUBSTRATE. Most often lignicolous, on rotten wood as well as on bark; also frequently saxicolous and terrestrial.

\section{ALTITUDE. 770-3960 m.}

DisTRIBUTION. Widely distributed and common in Africa: Macaronesia (Cape Verde Islands); west tropical Africa (Ghana, Guinea, Ivory Coast, Nigeria); northeast tropical Africa (Ethiopia); west central tropical Africa (Bioko, Central African Republic, Cameroon, Democratic Republic of the Congo, Gabon); east tropical Africa (Kenya, 
Rwanda, Tanzania, Uganda); south tropical Africa (Angola, Malawi, Zimbabwe); southern Africa (Lesotho, South Africa); and western Indian Ocean (La Réunion, Mascarenes); common and wide-spread in Tanzania: Arusha (Mt. Meru, Ngorongoro), Kilimanjaro (Mt. Kilimanjaro, South Pare Mts), Morogoro (Nguru Mts, Uluguru Mts), and Tanga (East and West Usambara Mts).

SELECTED SPECIMENS: TANZANIA, Arusha, Meru Mts, Crosby 11107, 11169, 11172, 11189 (all MO), Kis \& Pócs 9141/B (EGR, L), Pócs 8664/E and $F$ (EGR, L), Pócs 8690/G, 88085/D, 88086/D and $G$ (all EGR, private herbarium Bruggeman-Nannenga), Pócs et al. 88096/F (EGR, private herbarium Bruggeman-Nannenga), Pócs \& Nsolomo 88139/E (EGR, private herbarium Bruggeman-Nannenga), Pócs \& Ochyra 88144/X and $88146 / C$ (both EGR, private herbarium BruggemanNannenga), Pócs et al. 88162/S (KRAM, private herbarium Bruggeman-Nannenga), Pócs 89263/C (EGR, private herbarium Bruggeman-Nannenga), Sharp et al. 27, $41 A$ and 708 (all EGR, L), Sharp et al. 879B (EGR, private herbarium Bruggeman-Nannenga) and Whitehouse 26154 (MO); Ngorongoro, Van Zanten \& Pócs 86.07.228 (private herbarium Bruggeman-Nannenga, GRO), 86.07.231 (private herbarium Bruggeman-Nannenga, GRO), 86.08.286 (GRO, private herbarium Bruggeman-Nannenga), Pócs \& Chuwa 89017/B, 89025/W and $89027 / A F$ (all: EGR, private herbarium BruggemanNannenga) and Crosby 11160 (MO); Kilimanjaro, Mt. Kilimanjaro, Borrhidi et al. 87100/B (EGR, private herbarium Bruggeman-Nannenga), Gilbert 8477 (EGR, L), Pócs et al. 88122/B (KRAM, EGR, private herbarium Bruggeman-Nannenga), Pócs, Mjatta \& Linden 90021/ $A G$ (EGR, private herbarium Bruggeman-Nannenga), Pócs et al. 90027/N (EGR, private herbarium Bruggeman-Nannenga), Pócs 90131/A (EGR, private herbarium Bruggeman-Nannenga), Sharp 7150 (EGR, L, with $F$. asplenioides) and Sharp et al. 7560/A (EGR, L); South Pare Mts, Pócs et al. 90042/AL (EGR, private herbarium Bruggeman-Nannenga); Morogoro, Nguru Mts, Kiss \& Pócs 9112 /AM (EGR, L); Uluguru Mts, Crosby 7251 p.p. (MO), Pócs et al. 88110/CP (EGR, private herbarium Bruggeman-Nannenga) and Townsend 75/382 (E); Tanga, East Usambara Mts, near Amani, Pócs 6095/CJ (EGR, L); West Usambara Mts, Pócs 8436/AD (EGR, L) and Pócs 8450/ $Q$ (EGR, L).

SELECTED ILLUSTRATIONS: Bruggeman-Nannenga (2006a: fig. 1), Bruggeman-Nannenga \& Arts (2010: fig. 11), Chuah-Petiot (2003: fig. 26), Magill (1981: fig. 10: 1-8 as F. bryoides Hedw.).

\section{Fissidens artsii Brugg.-Nann.}

Fig. 3

Trop. Bryol. 26: 14, fig. 2. 2005. - TYPE: Réunion, La Caverne de la Glacière, sentier du Grand Bénard. On earth layer underneath overhanging volcanic rock, 2460 m, 8 III 1997, Arts 13/09 (HOLOTYPE: BR; ISOTYPE: L).

Growing in loose mats scattered between other species. Stem with central strand, 5.0-20.0 × 1.5$2.5 \mathrm{~mm}$, unbranched or branched, pinnate; rhizoids basal, brown and smooth; axillary cells differentiated, hardly bulging; leaves obscure, frequently with hyaline apex, up to 29 pairs, distant to close, not or slightly crispate when dry, lanceolate with acute-acuminate to rounded apiculate-mucronate apex, $0.8-2.2 \times 0.2-0.5 \mathrm{~mm}, \mathrm{~L} / \mathrm{W} 3-5$; limbate on all laminae; limbidium infrequently branched, frequently dentate at the leaf apex, mostly $( \pm)$ reaching the leaf apex; on the vaginant lamina distally confluent or not, reaching insertion of the vaginant lamina; in lower part of dorsal lamina often more or less fusing with costa; in mid dorsal lamina 4.5-9.5 $\mu \mathrm{m}$ wide and 1-2 stratose; on the vaginant lamina unistratose, marginal or weakly intramarginal; vaginant lamina $3 / 5-3 / 4$ the leaf length, closed to slightly open, unistratose; dorsal lamina narrow, straight to slightly rounded at base, often reaching the insertion as one row of cells, reaching the insertion or ending well above it, particularly in lower leaves often limbidioid near the insertion, not decurrent; dorsal and apical laminae unistratose; costa pale, stout, per- to excurrent; mid dorsal laminal cells roundish-hexagonal to quadrate, convex often with lenticularly thickened walls, $5.0-9.5 \times 4.5-8.0 \mu \mathrm{m}$; mid vaginant laminal cells $4.5-11.0 \times 3.5-8.0 \mu \mathrm{m}$; cells in leaf apex often clear and larger, $\pm 15 \mu \mathrm{m}$ long.

Fertile parts, perigonia terminal, male stems to $18 \mathrm{~mm}$ tall; antheridia $450 \mu \mathrm{m}$ long; perichaetia terminal, perichaetial leaves 1.6-2.5 mm long, archegonia 320-600 $\mu \mathrm{m}$ long. Sporophyte and calyptra unknown.

This species is characterized by limbate leaves, small, convex, often lenticularly thickened laminal cells (Fig. 3: 11), leaf tips that are frequently dentate and hyaline and dorsal laminae that frequently do not reach the insertion. In $\mathrm{KOH} \mathrm{5 \%} \mathrm{it}$ 


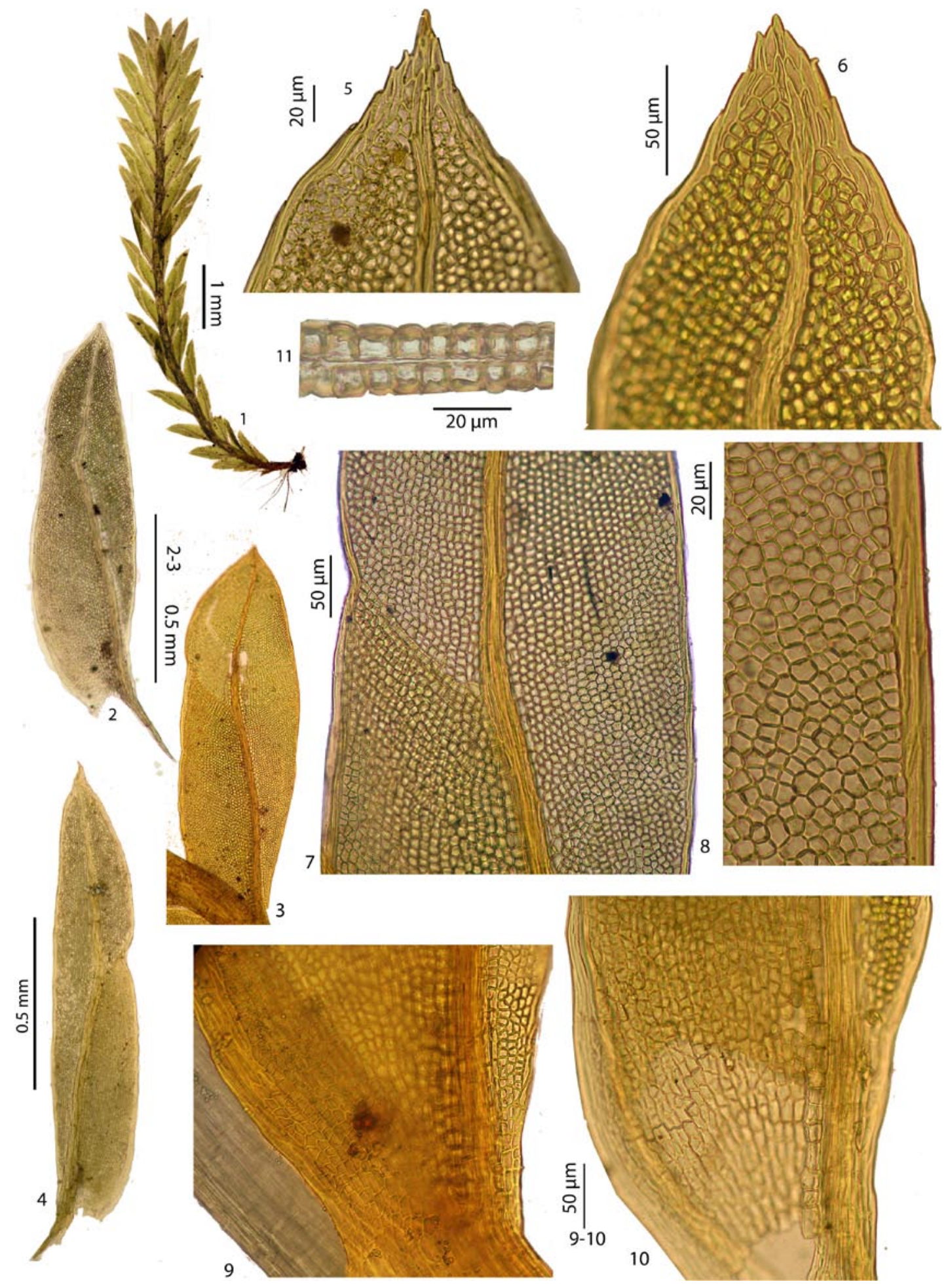


colors yellowish. It resembles $F$. megalotis subsp. helictocaulos which also has lenticularly thickened cell walls, but can be separated by its slightly open vaginant laminae and limbidia that are frequently intramarginal. Fissidens crispus also has obscure, limbate leaves and small, convex cells, but lacks hyaline leaf apices. Moreover, whereas in F. artsii the dorsal lamina frequently ends well above the insertion that of $F$. crispus is often long decurrent. Fissidens artsii resembles the neotropical $F$. wallisii Müll. Hal. in the denticulate leaf apex and the strongly thickened cell walls. Fissidens wallisii, however, has thicker limbidia (2-3 stratose instead of unistratose on the vaginant laminae).

HABITAT. Tree-heath forest (unspecified), Ericaceous heath and Phillipia bush with Erica arborea, on floor of cave; boulder in stream.

SUBSTRATE. On soil, respectively mud; also lignicolous and saxicolous.

\section{Altitude. 2460-3870 m.}

Distribution. East tropical Africa (Kenya, Tanzania, Uganda), and western Indian Ocean (La Réunion). New to Kenya, Tanzania and Uganda.

SPECIMENS EXAMINED: TANZANIA, Kilimanjaro, Kilimanjaro Mts, Pócs \& Van Zanten 86130/L (EGR, L), Van Zanten 86.08.437 (GRO) - KENYA, Mt. Elgon, Townsend 77/116b (E, private herbarium BruggemanNannenga); UGANDA, Ruwenzori, Newbould 5274 (E); Mt. Elgon, Wesche 1772 (private herbarium BruggemanNannenga). - LA RÉUNION, Arts 13/09 (holotype: $\mathrm{BR}$; isotype L).

ILLUSTRATIONS: Bruggeman-Nannenga (2005: fig. 2), Bruggeman-Nannenga \& Arts (2010: fig. 12).

\section{Fissidens beckettii Mitt.}

Fig. 4

J. Linn. Soc. Bot. 13: 225, 1873. - TYPE: Sri Lanka [Ceylon], Prov. Centr., Maanagalla, Beckett 9 (HOLOTYPE: NY; ISOTYPE: PC).

Fissidens simii Schelpe in Magill \& Schelpe, Trans. Roy. Soc. South Africa 44: 115. 1979 (new name for
F. aristatus Sim, Trans. Roy. Soc. South Africa 15: 200, f. 1926, hom. illeg.). This synonymy is based on two isosyntypes, viz. South Africa, Natal, Alexandra Park, Maritzburg, Sim 9907 (PC) and Zwart Kop Stream, Sim 9909 (PC) (Bruggeman-Nannenga, 1997). The same numbers are in Sim's herbarium in PRE (Magill 1981). The lectotype should be chosen from these.

Fissidens subpycnophyllus P. de la Varde, Arch. Bot. Bull. Mens. 4: 17, fig. 1: 1. 1930, p.p. - TYPE: Central African Republic [Oubangui], près Torogwadé, $60 \mathrm{~km}$ E. Bambari, Tisserant s.n. (LECTOTYPE designated by Bruggeman-Nannenga 1997: PC-PV). The type-collection contains two stems, both pictured in the protologue as F. subpycnophyllus. However, only the vegetative one is $F$. beckettii.

Fissidens smiloides P. de la Varde, Rev. Bryol. Lichénol. 5: 84, fig. 1. 1933. - LECTOTYPE (nov.): Central African Republic [Oubangui], Bozoum, sur terre, savanne, 26 VII 1931, Tisserant 549 [P Varde 4465B] (PC-PV).

Fissidens acanthophyllus P. de la Varde, Rev. Bryol. 9: 197, fig. 2. 1937. - HOLOTYPE: Central African Republic [Oubangui], Bocaranga, Eckendorff s.n. [RPV 5970] (PC-PV).

Growing in dense mats or scattered between other mosses (often tiny Fissidens species); stem without central strand, mostly unbranched, more or less heterocaulous; rhizoids basal, brown to hyaline, smooth; axillary cells not differentiated; perichaetial stems frondiform to elongate frondiform, 2-6 × 1-2 mm; perichaetial stem leaves more or less crowded, 5-10 pairs, $0.90-1.40 \times$ $0.25-0.50 \mathrm{~mm}, \mathrm{~L} / \mathrm{W} \pm 4$; vegetative stems rare, pinnate, $1.5-6.0 \times 0.7-2.0 \mathrm{~mm}$ wide; leaves more or less distant, 5-20 pairs, hardly altered when dry, lanceolate, ovate-lanceolate to elliptico-lanceolate with narrowly acute to long acuminate or mucronate apex, $0.40-0.85 \times 0.10-0.25 \mathrm{~mm}, \mathrm{~L} / \mathrm{W} \mathrm{3-5}$, margin limbate; limbidium on all laminae of upper and mid leaves, in lower leaf pairs poorly developed to lacking, reaching the leaf apex or not, confluent with the costa or not; at the apex of smaller lamella of the vaginant lamina confluent with the costa, $( \pm)$ reaching the insertion of the vaginant

Fig. 3. Fissidens artsii Brugg.-Nann. 1 - vegetative stem; 2-4 - leaves; 5 \& 6 - leaf apices; 7 - mid leaf; 8 - mid dorsal lamina; $9 \& 10$ - basal parts of leaf; 11 - trans section vaginant lamina showing the lenticularly thickened exterior walls. $1,2,6 \& 10$ from type specimen Arts 13/09 (L); 3 \&7 from Pócs \& Van Zanten 86130/L (L); 5, 8 \& 9 from Townsend 77/116b (E); 4 \& 11 from Newbould 5274 (E). 
lamina, reaching the insertion of the dorsal laminae or not, in mid dorsal lamina 6-16 $\mu \mathrm{m}$ wide and 1-2 stratose; on vaginant lamina 1-2 stratose, lax, marginal to indistinctly intramarginal near the insertion; vaginant lamina $1 / 2-7 / 10$ the leaf length, nearly or completely open, unistratose; dorsal lamina tapering towards the insertion, slightly rounded to straight at insertion, reaching the insertion, in lower leaves sometimes ending above, not to hardly decurrent; apical lamina lacking in lower leaves; dorsal and apical laminae unistratose; costa stout, percurrent to long excurrent; laminal cells rather uniform throughout the leaf, clear, oblong-hexagonal; mid dorsal laminal cells plane, smooth, 9.0-25.5 × 6.0-12.0 $\mu \mathrm{m}$; mid vaginant laminal cells $16.0 \times 8.0-9.5 \mu \mathrm{m}$; tubers present in some collections.

Fertile parts, perigonia terminal on short, $\pm 0.5 \mathrm{~mm}$ long, stems; antheridia not observed; perichaetia terminal, rarely terminal on branches, archegonia 200-350 $\mu \mathrm{m}$ long; perichaetial leaves 1.0-1.9 mm long; sporophyte, seta 3-7 mm long, smooth; capsule inclined to horizontal, rarely erect, $0.4-1.0 \times 0.3-0.5 \mathrm{~mm}$, with $40-54$ columns of oblong, exothecial cells; peristome bryoides type, tooth base $40-52 \mu \mathrm{m}$ wide; operculum rostrate, 0.25-0.45 mm long; calyptra not split; spores 9.5-22.5 $\mu \mathrm{m}$ long, weakly papillose to smooth.

Fissidens beckettii is characterized by its open vaginant lamina; large, 9.0-25.5 × 6.0-12.0 $\mu \mathrm{m}$, mid dorsal laminal cells; limbate, lanceolate leaves with a mucronate, acuminate or narrowly acute apex; percurrent to long excurrent costae; and inclined to horizontal capsules. Leaves of female stems are usually longer, wider and closer than those of sterile stems. Not all collections contain both fertile and vegetative stems. Fissidens beckettii can be confused with other species with an open vaginant lamina. Of these $F$. magnicellulatus can be distinguished by its vague, instead of distinct vaginant laminal limbidia and its even larger cells $(32-60 \times 8-15 \mu \mathrm{m})$, whereas $F$. rufescens has smaller, 5-13 $\times 5-8 \mu \mathrm{m}$, laminal cells with convexly thickened walls. Specimens with recurved leaf tips can be taken for F. pygmaeus Hornsch. (not known from tropical eastern Africa) which is easily distinguished by its elimbate dorsal and apical laminae. Fissidens curvatus, with which it may grow mixed, has closed to slightly open vaginant laminae.

East African collections of $F$. beckettii are rare and small. Therefore the description of the cross-sections is based on West African material (Eckendorff s.n.). The absence of a central strand is supported by observations by Iwatsuki and Suzuki (1982) and Pursell (2007). Limbidia are 1-2 stratose in Eckendorff s.n., 1-2 stratose according to Iwatsuki and Suzuki (1982, plate XV) and unistratose according to Pursell (2007).

West African F. beckettii is distinctly heterocaulous and frequently has long vegetative stems with distant leaves (Fig. 4: 10, 11). Such long vegetative stems were not seen in East African material.

HABITAT. Occurring in a variety of forest types: montane rain forest, submontane rainforest, montane evergreen forest, microphyllous dry evergreen forest, dry and mesophilous forest, mixed deciduous woodland; also cultivated areas (garden and plantation).

SUBSTRATE. In Tanzania mostly on soil; once on earth covered rocks, and once on a termite mound.

Altitude. In Africa 25-2100 m.

Distribution. Neotropics, Asia and Africa. In Africa known from west-central tropical Africa (Central African Republic), northeast tropical Africa (Ethiopia), east tropical Africa (Tanzania, Uganda), south tropical Africa (Zimbabwe) and southern Africa (South Africa). In Tanzania widespread, but uncommon: Arusha Region (Longido Hill), Dodoma Region (Chenene Hills), Mbeya Region (Mbeya), and Morogoro Region (Nguru Mts, Ukaguru Mts, S-Uluguru Mts).

SPECIMENS EXAMINED: TANZANIA, Arusha, Longido Hill, Pócs 8693/AE, a few stems mixed with other species (EGR, L), Pócs et al. 87165/AC, a few stems mixed with other Fissidens species (EGR, private herbarium Bruggeman-Nannenga); Dodoma, Chenene Hills, Polhill \& Paulo B9 (E, mixed with F. curvatus, PC); Mbeya, Mbeya District, Townsend 75/330 p.p. (E, 1 stem in mix); Morogoro, Nguru Mts, Pócs 88041/B 


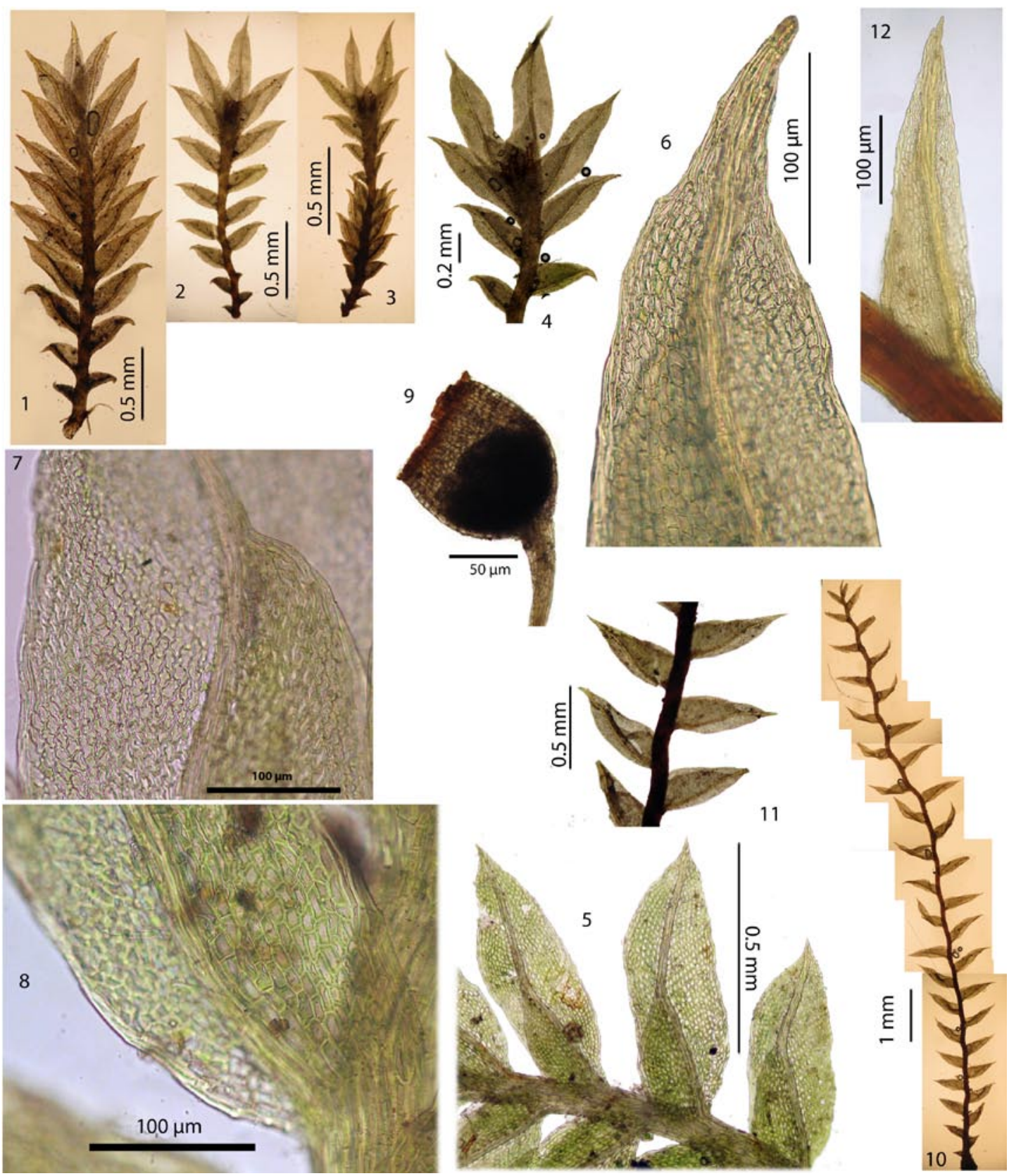

Fig. 4. Fissidens beckettii Mitt. (1-9 from Eastern Africa). 1 - vegetative stem; 2 \& 4 - perichaetial stems; 3 - perichaetial stem (not branch) growing as continuation on a vegetative stem; 5 - mid leaves of vegetative stem; 6 - apex; 7 - mid leaf; 8 - basal part of leaf; 9 - capsule; (10-12 from Western Africa). 10 - vegetative stem; 11 - mid leaves of vegetative stem; 12 - vegetative leaf. 1 from Wager 89 (BM); 2-4 \& 6 from Arts RSA 20/02 (BR); 5 from Hylander 4535 (private herbarium Bruggeman-Nannenga); 7 \& 9 from Polhill \& Paulo B9 (E); 8 from Pócs 8693/AE (L); 10 \&11 from Eckendorff s.n. (PC); 12 from Tisserant 549 (PC). 
a few stems mixed with $F$. enervis (EGR, private herbarium Bruggeman-Nannenga), Kis \& Pócs 9104/P (a few stems mixed with $F$. enervis and $F$. crispus (EGR, L); Ukaguru Mts, Pócs et al. 6743/D (EGR, PC a few stems mixed with type of $F$. pseudoeenii); S. Uluguru Mts, Pócs $6212 / D$ p.p. a few stems only (PC, EGR). - CENTRAL AFRICAN REPUBLIC [Oubangui], affluent de la Pendé, Eckendorff s.n. (Potier de la Varde 6482) (PC-PV); Bocaranga, Eckendorff s.n. (PC-PV); Bozoum, Tisserant 549 (PC-PV) and Tisserant 667 (PC-PV). - ETHIOPIA, Kaffa, Hylander 4535 (private herbaria: Hylander and Bruggeman-Nannenga). - SOUTH AFRICA, Cape Prov., Arts RSA 20/20 (BR, private herbarium Bruggeman-Nannenga); Transvaal, Pretoria, Townsend 82/6 (E, private herbarium Bruggeman-Nannenga).

SELECTED ILLUSTRATIONS: Arts (1998: fig, 6), Bruggeman-Nannenga (2006a: fig. 3), Iwatsuki \& Suzuki (1982: pl. 15), Magill (1981: 47: fig. 25-31 as F. simii), Potier de la Varde (1932: fig. 1 as F. smiloides; 1936: fig. 2 as F. acanthophyllus), Pursell (2007: fig. 49 A-C).

\section{Fissidens bogosicus Müll. Hal. in Venturi}

Fig. 5

Nuovo. Giorn. Bot. Ital. 4: 10. 1872. - TYPE: Ethiopia, Bogos-area near Keren, 1870, Beccari s.n. (LECTOTYPE designated by Bruggeman-Nannenga 1997: H-SOL (re-examined for this paper); ISOTYPES: BM, NY, PC-PV).

Fissidens microandrogynus Dixon, S. African J. Sci. 18: 306. 1922. - TYPE: Zimbabwe [Southern Rhodesia], Bailee, Wager 895 (HOLOTYPE BM; ISOTYPE PC-PV). Synonymy confirmed for this paper.

Fissidens hyalobasis Dixon in Sim, Trans. Roy. Soc. South Africa 15: 195, f. 1926. - TYPE: South Africa, Transvaal, Moorddrift, Wager 406 (HOLOTYPE BM; ISOTYPES: H-BR, PC-PV, both s.n.). Synonymy confirmed for this paper based on a photograph of the type-specimen.

Growing scattered or in loose mats; stem with weak central strand; rhizoids basal and axillary, hyaline to pale brown, smooth; axillary cells weakly differentiated; slightly heterocaulous; vegetative stems unbranched, $2.2-3.0 \times 1.0 \mathrm{~mm}$, pinnate; leaves distant, 11-16 pairs, slightly crispate or inflexed when dry, elliptical, elliptical-lanceolate, elliptico-oblong, acute less often broadly acute to obtuse, $0.35-0.80 \times 0.17-0.23 \mathrm{~mm}$, L/W 2.53.5 , margin subentire to weakly and irregularly crenulate, elimbate or infrequently with a weak limbidium of a few elongated cells near the insertion of the vaginant laminae (vaginant lamina of upper and mid leaves of perichaetial stems partly or completely limbate with intramarginal or marginal, unistratose limbidia); vaginant lamina $3 / 5$ the leaf length, unistratose, slightly open to almost completely open; in perichaetial leaves sometimes open; dorsal lamina narrow and slightly rounded at the insertion, reaching the insertion or not, not decurrent, dorsal and apical laminae unistratose; costa ending 2-4 cells below the apex; mid dorsal laminal cells clear, hexagonal, plane, smooth, 9.5$14.5 \times 8.0-11.0 \mu \mathrm{m}$; mid vaginant laminal cells hexagonal to oblong, $8.0-17.5 \times 5.0-1.0 \mu \mathrm{m}$; vaginant laminal cells of perichaetial stems frequently inflated, $17.0-51.0 \times 8.0-16.0 \mu \mathrm{m}$.

Fertile parts. Perigonia, perichaetia and infrequently synoicia. Perigonia terminal on short stems at base of perichaetial stems and terminal on branches, male stems budlike or longer, 0.4-3.5 mm long; antheridia 150-270 $\mu \mathrm{m}$ long; perichaetia and synoicia terminal, occasionally a few archegonia in axils of subperichaetial leaves; perichaetial and synoicial plants similar, unbranched to strongly branched, variable, 2.5-4.0 $\times 1.0-2.0 \mathrm{~mm}$, with 6-10 pairs of distant leaves (crowded in the perichaetium); perichaetial leaves 1.0-1.2 mm long with broadly acute to rounded obtuse apices; archegonia 220-350 $\mu \mathrm{m}$ long. Sporophyte, seta 3-6 mm long, smooth,1-2 per perichaetium; capsule slightly inclined or erect, $0.6-0.9 \times 0.35-0.55 \mathrm{~mm}, 62$ columns of oblong exothecial cells; peristome bryoides type, tooth base $32-64 \mu \mathrm{m}$ wide; operculum rostrate,

Fig. 5. Fissidens bogosicus Müll. Hal. 1 - sporophytic stem; 2-4-perichaetial plants; 5 \& 6 - vegetative stems; 7 - perichaetial stem with perichaetial branch and small basal perigonial stem; 8 \& 9 - leaves; 10 - leaf apex; 11 - mid leaf; 12 - basal part of leaf. 1, 5 \& 8 from type F. bogosicus (H-SOL); 2 \& 6 from Pócs \& Magombo 9176/O (L); 3 from Hodgets 2360A (private herbarium Bruggeman-Nannenga); 4, 7, 9-12 from Pócs 90070/C (private herbarium Bruggeman-Nannenga). Rusty coloring of $1,3,5 \& 8$ is caused by $5 \% \mathrm{KOH}$. The coloration of $11 \& 12$ has been manipulated to make some details better visible. 


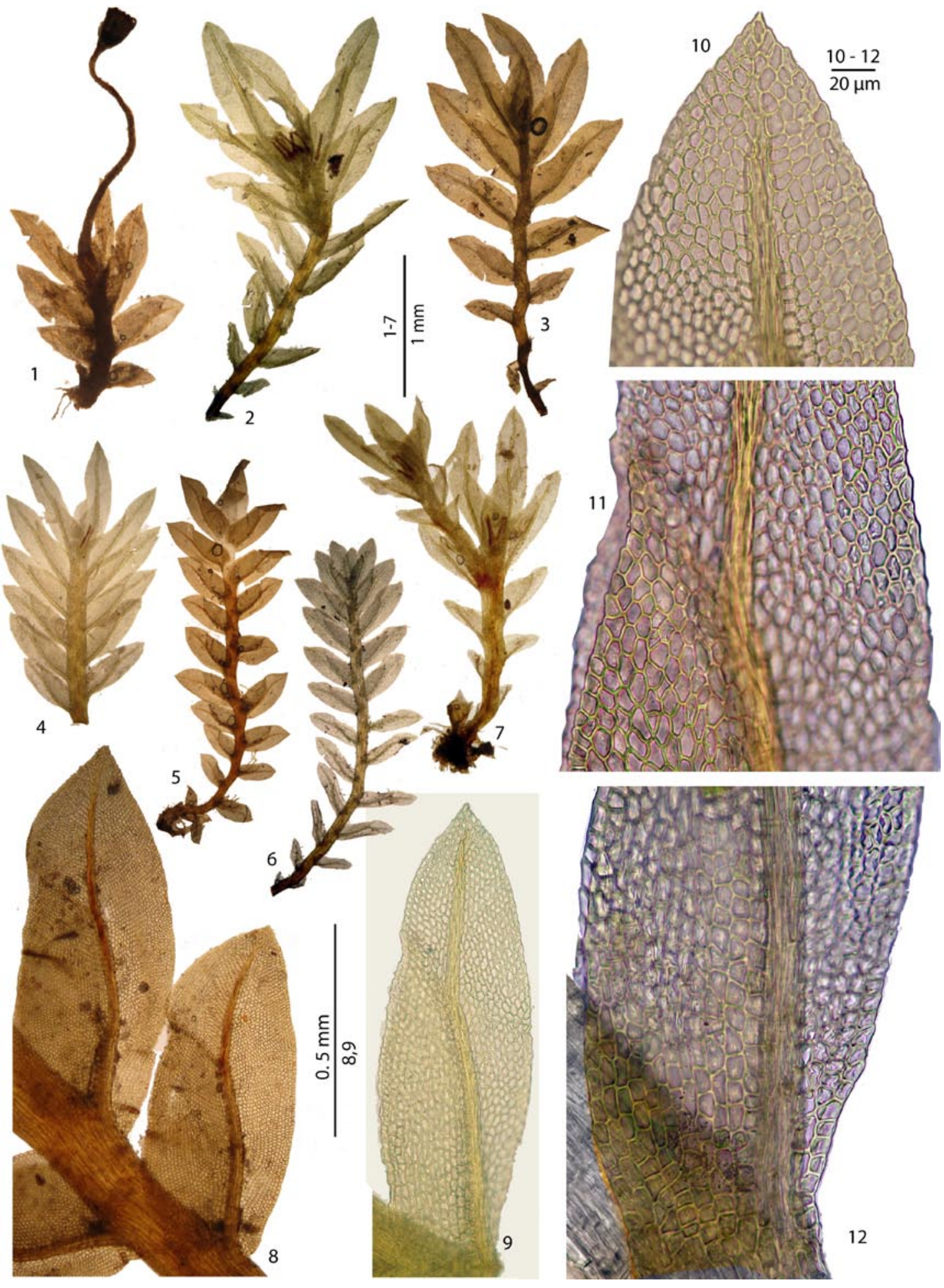


0.3-0.4 mm long; calyptra smooth, $0.4 \mathrm{~mm}$; spores 17.5-33.0 $\mu \mathrm{m}$ long, papillose.

This variable species is characterized by vegetative stems with elimbate or \pm elimbate leaves, and perichaetial stems with partly or completely limbate vaginant laminae on upper and mid leaves. It is most likely to be confused with other incompletely limbate species. Of these $F$. taylorii differs by being distinctly heterocaulous with short, frondose perichaetial stems with narrower leaves and leaf apices (compare Fig. 17: 2 and Fig. 5: 1-4, 7 with Fig. 17: 4, 5). Moreover, F. taylorii frequently has (weak) limbidia on all laminae in the upper leaves of perichaetial plants. In vegetative state the two species cannot be distinguished (Fig. 17: 1 and 3). Fissidens rotereaui, with which it may grow mixed, differs by vaginant laminae that are limbate in both vegetative and perichaetial stems and by ex- to percurrent costae. Fissidens gomae often has similarly shaped perichaetial stems, but is easily distinguished by its limbate leaves.

Note. My earlier concept of $F$. bogosicus (Bruggeman-Nannenga 1997) included F. taylorii and $F$. rotereaui. Therefore, all synonyms proposed there need to be re-examined. This is not finalized in this paper.

HABITAT. Montane evergreen forest fragment, riverine evergreen forest, xerophyta bush, river bank, Syzygium thicket.

SubSTRATE. Saxicolous, less often on soil.

AltitUdE. 930-2200 m.

Distribution. Northeast tropical Africa (Ethiopia, Eritrea); east tropical Africa (Tanzania); south tropical Africa (Malawi, Zambia); and southern Africa (Botswana, South Africa).

The distribution in O'Shea (2006) needs revision as it is in part based on F. taylorii and $F$. rotereaui.
SPECIMENS EXAMINED: TANZANIA, Kilimanjaro Mts, Pócs 90070/C p.p. with F. megalotis subsp. helictocaulos and F. cryptoneuron (EGR, private herbarium Bruggeman-Nannenga). - BOTSWANA, Long 12465 (private herbarium Bruggeman-Nannenga). ERITREA, Schweinfurth s.n. (H-BR). - ETHIOPIA, Beccari s.n. (H-SOL). - MALAWI, Pócs \& Magombo 9176/O (EGR, L) and 9182/C (EGR, L, 2 stems in mix); Hodgetts 2360A (E, private herbarium BruggemanNannenga). - ZAMBIA, Townsend 75/19 (E, private herbarium Bruggeman-Nannenga).

\section{Fissidens crispus Mont.}

Fig. 6

Ann. Sci. Nat., Bot., sér. 2, 9: 57. 1838. - TYPE: Peru, ad terram arenosam in sylvis Provinciae Corrientes secus flumen S. Lucie cum Hypno microphyllo et Gymnostomo orbigniano, d'Orbigny s.n. (HOLOTYPE: PC-Mont; ISOTYPES: BM, FH, PC. Not seen).

Fissidens schmidii Müll. Hal., Bot. Zeit. (Berlin) 11: 18. 1853. - TYPE. India. Nilgiri, B. Schmid 43b (not seen, probably lost).

?F. mobukensis G. Negri, Ann. Bot. (Rome) 7: 163. 1908. - TYPE: M. Ruwenzori, in rupem inter Ibanda et Bihunga m. $2000 \mathrm{ca}$ (not seen). This is probably a synonym as according to the protologue the type has limbate leaves and small quadratic cells, but the type still needs to be checked.

Fissidens hoeegii P. de la Varde, Kongel. Norske Vidensk. Selsk. Forh. 5: 130, fig. 1-8. 1932. - TYPE: South Africa [Africa australis], prov. Natal, distr. Umgeni prope Pietermaritzburg in umbratis lapidibus, O. A. Høeg 423 (LECTOTYPE designated by Bruggeman-Nannenga 1997: PC-PV; ISOLECTOTYPE: BM) - syn. nov.

Fissidens cataractarum Demaret \& P. de la Varde, Bull. Jard. Bot. État Brux. 27: 755, fig. 77. 1957. - TYPE: Democratic Republic of the Congo [Congo belge], Distr. des Lacs Edouard et Kivu: Ruwenzori, Kyandolire, casacade de la Mulaka, alt. 1750 m, Juin 1953, Demaret 5939 (HOLOTYPE: BR; ISOTYPE: PC-PV). - syn. nov.

Scattered or in large mats; stem with central strand, branched or not, $1.5-5.5 \times 1.2-2.7 \mathrm{~mm}$, pinnate; rhizoids basal, brown, smooth; axillary

Fig. 6. Fissidens crispus Mont. 1 \& 2 - vegetative stem; 3 - sporophytic stem; 4 - perigonial stems; 5-7 - leaves; 8 \& 9 - leaf apices; 10 - mid leaf; 11 - margin mid dorsal lamina; 12 - basal part of leaf; 13 - axillary nodule. 1 \& 7 from Pócs $8405 / N$ (L); 2-5, 8, 12 \& 13 from $P$ 88281/N (private herbarium Bruggeman-Nannenga); 6 from Pócs et al. 88295/D (private herbarium Bruggeman-Nannenga); 9 from Maas Geesteranus 5147/F (L); 10 from Pócs 8664/F (L); 11 from Pócs \& Ochyra 88144/V (private herbarium Bruggeman-Nannenga). 

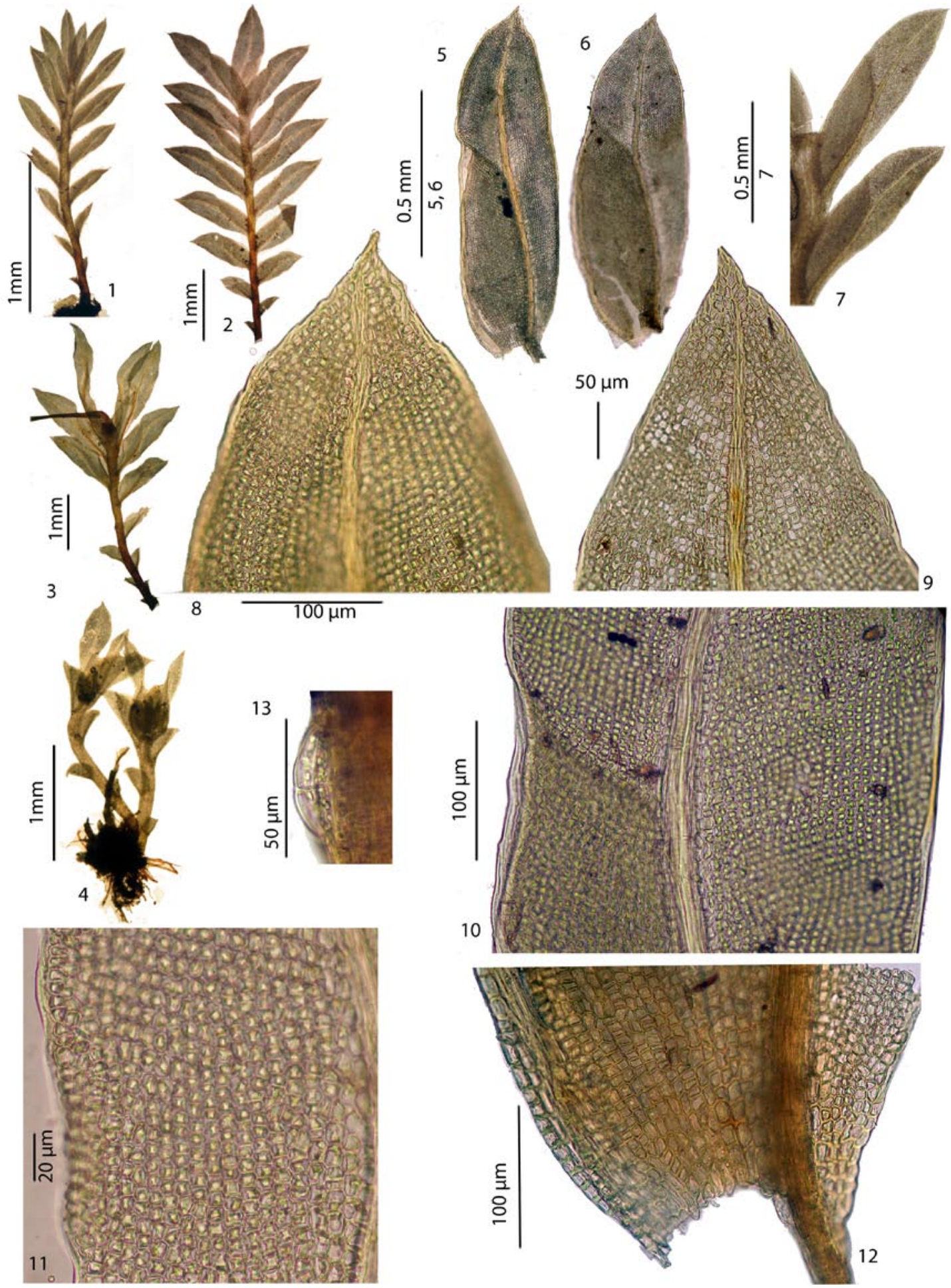
cells weakly differentiated; leaves green, obscure, close to distant, up to 15 pairs, strongly crispate when dry, elliptical, elliptico-lanceolate, broadly lanceolate to oblong, acute to acute-acuminate to obtuse apiculate, $0.6-1.2 \times 0.2-0.3 \mathrm{~mm}, \mathrm{~L} / \mathrm{W}$ 2.5-4.5, limbate; limbidium reaching the leaf apex or ending below; on dorsal laminae ending well above the insertion to reaching it, on the decurrent part present or not, in mid dorsal lamina 4.5-16 $\mu \mathrm{m}$ wide, uni- to bistratose; on vaginant lamina reaching the insertion and confluent at the apex, uni- to bistratose, marginal to intramarginal by $1-2$ cell rows; vaginant lamina $3 / 5-3 / 4$ the leaf length, closed, unistratose; dorsal lamina straight to slightly rounded below, undulate or not, reaching the insertion, not to long decurrent; dorsal and apical laminae unistratose or unistratose with some bistratose dots; costa ending 2 cells below the leaf tip to percurrent; laminal cells obscure, quadratic to oblong, often arranged in rows, convex, in mid dorsal lamina 3.0-9.5(-12.0) × 3.0-7.5 $\mu \mathrm{m}$; mid vaginant laminal cells $8.0-13.0 \times 5.0-8.0 \mu \mathrm{m}$.

Fertile parts. Perigonia terminal on stems and on (not bud-like) branches, male stems 1-4 mm long, antheridia 150-300 $\mu \mathrm{m}$; perichaetia terminal, perichaetial stems 3.4-4.0 mm long, hardly different from vegetative stems; archegonia 300$400 \mu \mathrm{m}$ long; perichaetial leaves $1.6-2.2 \mathrm{~mm}$ long, in some collections almost twice as long as mid stem leaves; seta 3-5 mm long, smooth, 1 per perichaetium; capsule symmetrical, $0.65-1.00 \times$ $0.30-0.45 \mathrm{~mm}$ with $52-58$ columns of oblong exothecial cells; peristome bryoides type, tooth base 30-56 $\mu \mathrm{m}$; operculum rostrate, $0.4 \mathrm{~mm}$ long; calyptra mitrate, smooth, 0.6-0.7 mm; spores subglobose, $12.0-22.5 \mu \mathrm{m}$ diam., \pm smooth to faintly papillose.

This species is characterized by obscure leaves, small, slightly to strongly convex \pm quadratic laminal cells arranged in rows. Most collections can be recognized at a low magnification by the obscure leaves and often delicate limbidia. When $F$. crispus does not flatten in water $5 \% \mathrm{KOH}$ will usually help. In $\mathrm{KOH}$ the specimens turn brown, particularly the costa and limbidia. Specimens that are hard to distinguish from $F$. androgynus are frequently seen (see also under $F$. androgynus). Both species are common and occur in a wide variety of habitats on a wide variety of substrates and often grow mixed. Typically $F$. androgynus has clear leaves and larger, not quadratic, plane to slightly convex laminal cells. Both species can have long decurrent dorsal laminae and marginal or intramarginal limbidia. For differentiation from $F$. artsii see under that species.

HABITAT. In a wide variety of wet to dry habitats, but mostly in forests, e.g. rainforests (montane $2 \times$, submontane $1 \times$ ); dry evergreen forests $(5 \times)$, mesic evergreen montane forests $1 x$; riverine evergreen forests $1 \times$ ), dry semideciduous forests $(2 \times)$, Hagenia forests $(4 \times)$, Cupressus lustanica plantations $(6 \times)$; unspecified forests; mature, mist affected, but heavily grazed Acacia stand; remnants of Juniperus excelsa forest; also in xeric bush on rock outcrop $(1 \times)$; dambo-like swamp and moorland vegetation $(1 \times)$; on sandy/peaty bank by stream in deep shade $(1 \times)$; near cascades $(2 \times)$; and on a roadside bank.

SUBSTRATE. Most often lignicolous (corticolous or on roots ( $9 \times$ of which 2 on coniferous bark) and on (rotting) wood $(8 \times)$; also frequently rupicolous ( $8 \times$ including 2 finds on concrete and one from an earth covered rock) and on soil $(10 \times)$.

Altitude. 1000-2500 m. In Bruggeman-Nannenga (2006b) this species (as $F$. schmidii) was reported from $3870 \mathrm{~m}$. This specimen, however, is now identified as $F$. artsii.

Distribution. Pantropical, in Africa known from west tropical Africa (Guinea, Nigeria, Sao Tome); west-central tropical Africa (Bioko, Central African Republic, Cameroon, Democratic Republic of the Congo, Gabon); northeast tropical Africa (Ethiopia); east tropical Africa (Kenya, Tanzania, Uganda); and southern Africa (Lesotho, South Africa). Widespread and common in Tanzania: Arusha (Mt. Meru, Ngorongoro); Kilimanjaro (Kilimanjaro Mts); Iringa (Southern Highlands); Mbeya (Mbeya); and Tanga (West Usambara Mts).

Selected SPeCimens: TANZANIA, Arusha, Mt. Meru, Pócs 8664/B, C, F, P(EGR, L), Pócs 8678/R (with F. megalotis subsp. helictocaulos), $T, U, V$ (EGR, L), 
Pócs 88085/D, $J$ (EGR, private herbarium BruggemanNannenga), Pócs et al. $88086 / D, G, X$ (EGR, private herbarium Bruggeman-Nannenga), Pócs 88139/E (KRAM, private herbarium Bruggeman-Nannenga), Pócs \& Nsolomo 88140/D (EGR, KRAM, private herbarium Bruggeman-Nannenga), Pócs \& Nsolomo 88140/Q (EGR, private herbarium Bruggeman-Nannenga), Pócs 88141/A (EGR, private herbarium Bruggeman-Nannenga), Pócs \& Ochyra 88144/J, V, Z (EGR, private herbarium Bruggeman-Nannenga), Pócs et al. 88162/S (KRAM, private herbarium Bruggeman-Nannenga), Pócs et al. 88295/D (EGR, private herbarium Bruggeman-Nannenga), Sharp 858 A (EGR, L), Sharp, Gilbert \& Suso 9786 p.p. plus F. megalotis subsp. helictocaulos (EGR, L); Ngorongoro Conservation Area, Pócs \& Chuwa 88280/S (EGR, private herbarium BruggemanNannenga), 88281/AA, N (EGR, private herbarium Bruggeman-Nannenga), 89019/T (EGR, private herbarium Bruggeman-Nannenga), 89031/AW p.p. (EGR, private herbarium Bruggeman-Nannenga), Van Zanten \& Pócs 86.07.220 and 8607227 (both GRO, private herbarium Bruggeman-Nannenga); Kilimanjaro, Kilimanjaro Mts, Pócs 6237/F (PC), Pócs 90126/E (EGR, private herbarium Bruggeman-Nannenga); Pócs 90134/E mixed with $F$. loennbergeri (EGR, private herbarium Bruggeman-Nannenga), Gilbert 21/B (EGR), $29 B$ (EGR, L), Van Zanten \& Pócs 86.08.334 (GRO, private herbarium Bruggeman-Nannenga); Iringa, Southern Highlands, Pócs 8637/L (EGR, private herbarium BruggemanNannenga); Mbeya District, Townsend 75/330 p.p. (E); Tanga, West Usambara Mts, Pócs 8405/N (EGR, L), $8436 / Z$ (EGR, L) and $8546 / D$ (EGR, L).

ILLUSTRATIONS: Bruggeman-Nannenga (2006b: fig. 22 as F. schmidii), Demaret \& Potier de la Varde (1957: 77 as $F$. cataractarum), Iwatsuki \& Suzuki (1982: pl. X as F. bryoides var. schmidii), Magill (1981: fig. 9: 8-14 as F. hoeegii), Pursell (2007: fig. 38: A-E).

\section{Fissidens curvatus Hornsch.}

Linnaea 15: 148. 1841. - TYPE: South Africa, Cape Prov., 4 X 1827, Ecklon s.n. (LECTOTYPE designated by Magill 1981: H-BR; ISOLECTOTYPES: S, BM both as 'An einer Mauer in Mr. Auret's Garten unter dem Löwenrücken, 24 October. 1827, Ecklon s.n.').

\section{F. curvatus var. curvatus}

Fig. 7

Fissidens algarvicus Solms, Tent. Bryo-geogr. Algarv.: 41. 1868. - HolOTYPE: Portugal, in Algarve humidiusculus argillaceis ad oppidum silves Perrara stirps, Leptotrichi subulati caespitibus parce immixta; Flora lusitanica Algarve 18. Silves ad terram. Solms, 1866 (GOET).

Fissidens macleanus J. Shaw, Cape Monthly Mag. 17: 314. 1878. - TYPE: South Africa, Cape Prov., Graaf Reynett, MacLea s.n. as Rehmann Musci Austro-Africani 583 (easily misread as 533) (LECTOTYPE designated by Bruggeman-Nannenga 1997: H-BR; ISOLECTOTYPE: PC mixed with a few stems of F. megalotis).

Fissidens sericeus Broth., Bot. Jahrb. Syst. 20: 181. 1894. - TYPE: Tanzania, Usambara, Kwa Mshusa-Station, bei Msingo, $1600 \mathrm{~m}$, am Boden, Holst 9195, p.p. (HOLOTYPE: H-BR; ISOTYPE: PC).

Fissidens attenuatus Bryhn, Kongel. Norske Vidensk. Selsk. Skr. (Trondheim) 8: 16. 1908. - LECTOTYPE (nov.): Tenerife, Las Mercedes. Lat. sept. 28 30', 600 m, 19 V 1908. Bryhn s.n. (H-BR).

Fissidens fritzei Geh., Biblioth. Bot. 73: 55, T. IA. 1910. - LeCtOTYPE (nov.): Madeira, Fritze s.n. (H-BR).

Fissidens angustinervis Thér., Recueil Publ. Soc. Havraise Etudes Diverses 90: 80. 1923. - TYPE: Madagascar, Tananarive, Décary s.n. (HOLOTYPE: PC; ISOTYPE: H-BR).

Growing in dense mats. Stem with central strand, heterocaulous; rhizoids basal, bright brown, smooth; axillary nodules weakly differentiated, hyaline; perichaetial stems branched or unbranched, 1.4-1.6 × 0.7-0.8 mm (occasionally longer and similar to vegetative stems); perichaetial stem leaves \pm frondiform, crowded to slightly distant, up to 6 pairs that differ much in shape and size; vegetative stems mostly unbranched, $2.0-5.0 \times$ 0.7-1.2 mm, pinnate; leaves green, distant to somewhat crowded, up to 20 pairs, hardly altered when dry, linear-elliptical to linear-lanceolate, acute-acuminate to mucronate, symmetric or asymmetric, $0.70-0.95 \times 0.15-0.20 \mathrm{~mm}, \mathrm{~L} / \mathrm{W} 3.5-6$, limbate on all laminae of all leaves; limbidium confluent at the leaf apex, reaching the insertions of the dorsal and vaginant lamina, confluent at the apex of the vaginant lamina; on mid dorsal lamina 13.0-14.5 $\mu \mathrm{m}$ wide, bistratose; on vaginant laminae 1-2 stratose, marginal; vaginant lamina 2/3-3/4 the leaf length, closed, unistratose; dorsal lamina narrowed below, reaching the insertion to ending well above, in basal part often limbidioid, not decurrent, dorsal and apical laminae unistratose; costa per- to long excurrent; mid dorsal laminal cells smooth (but see 

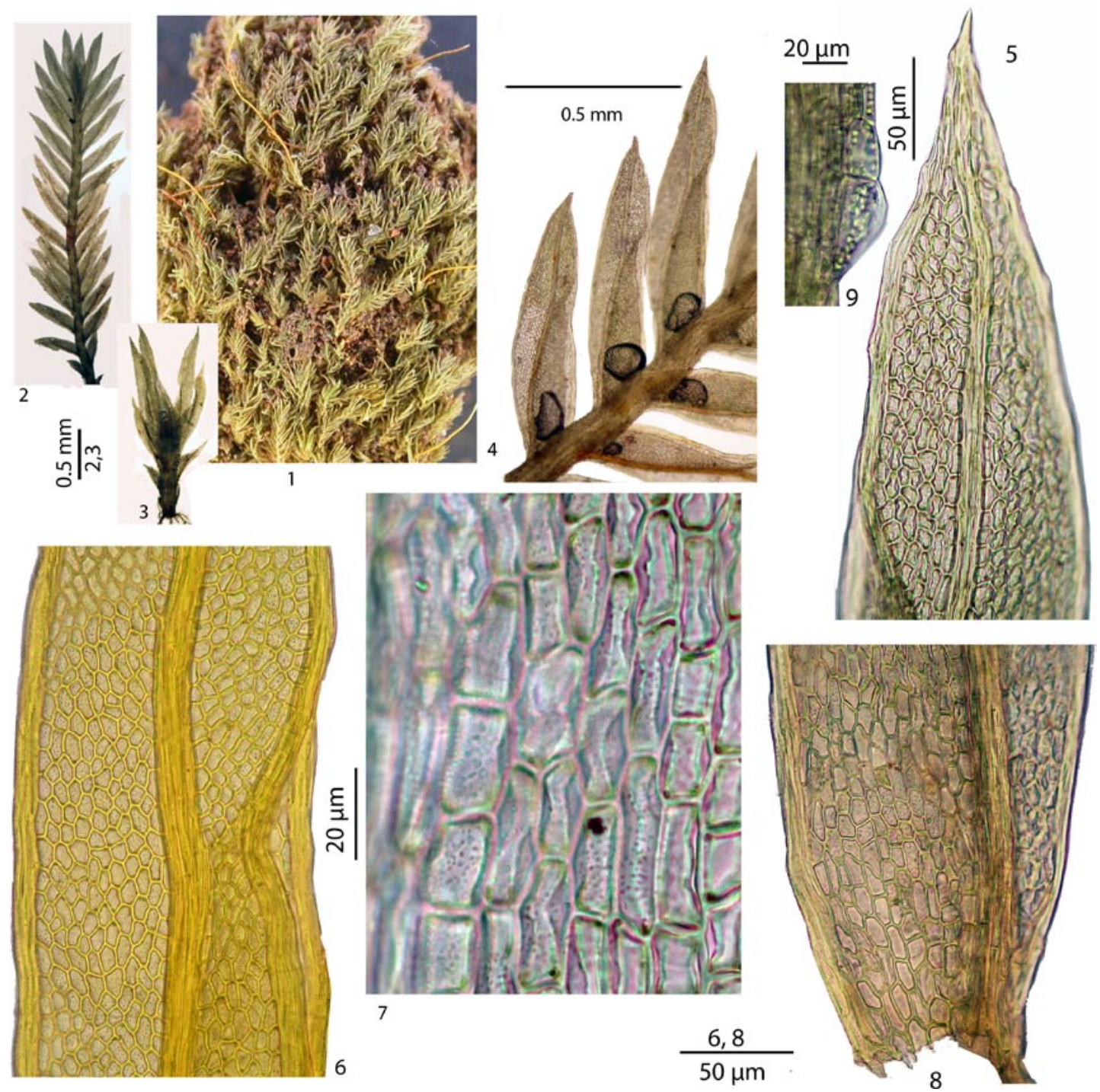

Fig. 7. Fissidens curvatus Hornsch. 1 - habit; 2 - vegetative stem; 3 - perichaetial stem; 4 - leaves; 5 - leaf apex; 6 - mid leaf colored yellow by $5 \% \mathrm{KOH} ; 7$ - mid vaginant laminal cells with (pseudo?) papillae; 8 - basal part of leaf; 9 - weak axillary nodule. 1, 4 \& 7 from Pócs 8540/Q (L); 2, 3, 6 \& 8 from Pócs 8401/J (L); 5 from Pócs 8450/P (L); 9 from Pócs 8540/Q (L).

note below), plane, oblong-hexagonal, 8.0-16.5 × 5.0-8.0 $\mu \mathrm{m}$; mid vaginant laminal cells oblong, $6.0-17.5 \times 4.5-6.5 \mu \mathrm{m}$.

Fertile parts, perigonia terminal on short, often bud-like stems at base of perichaetial and vegetative stems, less often on short, budlike or longer branches of perichaetial stems; perigonial stems 0.35-0.90 mm long; antheridia 150-180 $\mu \mathrm{m}$ long; perichaetia terminal on stems or less often on branches from lower stem half; perichaetial leaves $0.6-1.0 \mathrm{~mm}$ long, archegonia $170-230 \mu \mathrm{m}$ long; seta 3.5-6 mm long, smooth, 1 per perichaetium; capsule strongly inclined to horizontal, $0.70 \times 0.45 \mathrm{~mm}$, with $40-48$ columns of oblong exothecial cells; peristome bryoides type, tooth base 36-51 $\mu \mathrm{m}$ wide; operculum conical to short 
rostrate, $0.2-0.3 \mathrm{~mm}$ long; calyptra 0.5 long, not split, smooth; spores $11-18 \times 8-13 \mu \mathrm{m}$, distinctly papillose.

Fissidens curvatus is characterized by limbate leaves, per- to excurrent costae and stout limbidia that are confluent with the costa; large, clear mid dorsal laminal cells; and pinnate vegetative stems with small, even-sized leaves that differ markedly from the shorter, frondose perichaetial stems. Characteristic, though not found in all collections are large oblong vaginant laminal cells (Fig. 7: $7,8)$. Equally characteristic and again not seen in all collections, are laminal cells that seem to be finely pluripapillose (see below). In the field $F$. curvatus is usually easily recognized by its stiff, pinnate vegetative stems with linear leaves (Fig. 7: 1, 2, 4). Fissidens curvatus colors yellow in 5\% $\mathrm{KOH}$. It may be confused with $F$. taylorii which differs by less well developed limbidia that do not reach the leaf apex and in the Tanzanian specimens are \pm restricted to the vaginant laminae mid and upper leaves of perichaetial stems.

Laminal cells of $F$. curvatus and $F$. rotereaui frequently seem finely papillose (Fig. 7: 7 and Fig. 15: 10). This was discussed by Potier de la Varde (1929). With a light microscope it is impossible to establish whether these cells are papillose or pseudopapillose.

HABITAT. In Tanzania most often on road banks and road cuttings; often in plantation forests; in addition in submontane rainforest $(1 \times)$, montane rainforest $(1 \times)$, remnants of Juniperus excelsa forest with Hagenia abyssinica $(1 \times)$, and mixed deciduous woodland $(1 \times)$.

SubSTRATE. Most Tanzanian specimens grow on soil and only rarely on rocks or wood; once collected on a termite mound.

Altitude. 0-3250 m.

DISTRIBUTION. Cosmopolitan, in the neotropics found from southern USA to Chile and Argentina; further known from St Helena, southwestern Europe, Australia, and New Zealand (BruggemanNannenga \& Pursell 1995). African distribution: Macaronesia (Azores, Canary Islands, Madeira); west tropical Africa (Nigeria); east tropical Af- rica (Kenya, Rwanda, Tanzania, Uganda); south tropical Africa (Malawi, Zimbabwe); southern Africa (Lesotho, South Africa, Swaziland); and western Indian Ocean (La Réunion, Madagascar). In Tanzania known from Arusha (Mt. Meru), Dodoma (Chenene Hills), Kilimanjaro (S. Pare Mts). Morogoro District (Nguru Mts, S-Uluguru Mts), Rukwa (Ufipa District), and Tanga (West Usambara Mts).

SPECIMENS EXAMINED: TANZANIA, Arusha, Mt. Meru, Laaka 879, 884, $886(\mathrm{H})$, Pócs et al. 88085/J, p.p. (EGR, private herbarium Bruggeman-Nannenga), Pócs et al. 88145/Q (EGR, private herbarium Bruggeman-Nannenga), Crosby 14447 with $F$. ovatus Brid. (MO); Dodoma, Chenene, Polhill \& Paulo B9 mixed with F. beckettii (E); Kilimanjaro, South Pare Mts, Pócs et al. 90042/AL (EGR, private herbarium BruggemanNannenga); Morogoro District, Nguru Mountains, Kiss 9128/F (EGR, L), S-Uluguru Mts, Pócs 6212/D with $F$. beckettii (EGR, PC), Pócs 6812/C (EGR, PC); Rukwa, Ufipa District, Townsend 80/275 (E); Tanga, West Usambara Mts, Pócs 8401/J (EGR, L), 8450/P, $S, R, S$ (EGR, L), 8540/Q, V (EGR, L), 89254/F (EGR, private herbarium Bruggeman-Nannenga).

SELECTED ILlUSTRATIONS: Beever et al. (2002: 24), Iwatsuki \& Suzuki (1982: pl. XVI as F. strictulus Müll. Hal.), Magill (1981: fig. 11: 1-8), Pursell (1994: fig. 43; 2007: fig. 51), Smith (1978: fig. 87 : 5-7 as F. algarvicus).

\section{Fissidens gladiolus Mitt.}

Fig. 8: 1-5

Trans. Linn. Soc. London 23: 55, tab. 6, fig. 16: 1-3. 1860; Nanobryum gladiolum (Mitt.) Bizot, Rev. Bryol. Lichénol. 38: 593. 1971[1973]. - HOLOTYPE: interior of Africa, Mungo Park (NY).

Nanobryum dummeri Dixon, J. Bot. 60: 101, pl. 564: 1a-g. 1922. - LECTOTYPE designated by Bizot 1963: Uganda, on damp earth and hollows of fallen trees in forest, Muhange, Nov. 1920, Dummer 4080 A (BM).

Anisothecium pallidisetum P. de la Varde, Bull. Soc. Bot. France 73: 380, fig. 32. 1926. - HolotyPE: Central African Republic, 7 km S Ippy. Rochers du Kaga Lekpwa. Endroit humide. 25 VII 1929, Tisserant 98 (PV 2079) (PC-PV).

Sparsely scattered between other species, rarely in mats; vegetative stems unknown, perichaetial stem unbranched, elongate frondiform, 1.0-6.0 $\times 0.8-2.5 \mathrm{~mm}$; rhizoids basal, pale brown and 
smooth, protonemata persistent (not observed in all collections); axillary nodules and cells not checked; leaves distant, 3-5 pairs, tortuose, difficult to straighten, linear-lanceolate; perichaetial leaves with or without dorsal and apical laminae, subulate, $1.5-2.9 \times 0.2-0.25 \mathrm{~mm}, \mathrm{~L} / \mathrm{W} 7.5-11.5$, margin entire, elimbate or limbate; limbidia often present on dorsal and apical lamina, in mid dorsal lamina ca $10.5 \mu \mathrm{m}$ wide, marginal; lacking or illdefined on the vaginant lamina; vaginant lamina $\pm 1 / 2$ as long as the leaf, unistratose, open, widely gaping, distal end of lesser lamella tapering or ending in a sharp, free tooth or deeply indented before tapering toward the costa; dorsal lamina when present tapering towards the insertion, reaching the insertion; dorsal and apical laminae probably unistratose (no trans-sections made) sometimes lacking; costa stout, percurrent in the long subula; mid dorsal laminal cells narrowly oblong, clear, firm-walled, variable in size, 45.0-82.5 $\times$ 4.5-9.0 $\mu \mathrm{m}$, smooth; inner vaginant laminal cells narrowly oblong, variable in size, 45.0-144.0 $\times$ 9.5-19.0 $\mu \mathrm{m}$, smooth; marginal vaginant laminal cells longer, forming an ill-defined limbidium.

Fertile parts, perigonia terminal on small, budlike stems; antheridia $150 \mu \mathrm{m}$ long; perichaetia terminal, archegonia 280-370 $\mu \mathrm{m}$ long. Sporophyte, seta 3-8 mm long, erect, smooth, 1-2 per perichaetium; capsule inclined to cernuous, $0.50-0.80 \times 0.25-0.50 \mathrm{~mm}, 40-60$ columns of irregularly oblong to quadratic exothecial cells; peristome bryoides type (only basal OP seen), teeth $39-51 \mu \mathrm{m}$ wide at base; operculum rostrate, $0.45-0.50 \mathrm{~mm}$ long; calyptra smooth, mitrate; spores subglobose, 9-15 $\mu \mathrm{m}$ long, smooth to faintly papillose.

This curious little species is characterized by perichaetial stems with long, subulate upper leaves with poorly developed, or occasionally lacking dorsal and apical laminae; \pm elimbate vaginant laminae of large, prosenchymatous cells; and persistent, thalloid protonemata (sometimes lacking). It is unlikely to be confused with any other species, except $F$. magnicellulatus. For differences see under that species and Fig. 8.

Unfortunately, F. gladiolus is known only from perichaetial stems with 3-5 leaf pairs. These are too short to have 'morphological mid stem leaves'. The species is variable and sometimes shows anomalies. For instance two specimens, including an isotype of $F$. gladiolus in BM, have extra laminae in addition to the usual dorsal and apical.

HABITAT. Eucalyptus plantation; dry evergreen forest.

SubSTRATE. On soil.

ALTITUDE. 770-2000 m.

DisTRIBUTION. West tropical Africa (Nigeria); west-central tropical Africa (Central African Republic, Gabon); east tropical Africa (Tanzania, Uganda); and southern Africa (South African Republic). A record from Zambia (BruggemanNannenga 2009) refers to F. magnicellulatus. Tanzanian distribution: Morogoro (Bizot \& Pócs 1979) and Tanga (West Usambara Mts).

SPECIMENS EXAMINED: TANZANIA, West Usambara Mts, Pócs, Ochyra \& Bednarek-Ochyra 88116/E a single stem mixed with $F$. megalotis subsp. helictocaulos (KRAM). - UGANDA, Bunyore Prov., Jones 572 (PC-PV); Kabarole, Wigginton U 3109A (E, L, 1 stem). - NIGERIA, Abeokuta province, Berry 902 (PC-PV). CENTRAL AFRICAN REPUBLIC, Assel 416 (PC).

SELECTED ILLUSTRATIONS: Bruggeman-Nannenga (2006a: fig. 9), Dixon (1922: pl. 564, fig. 1a-g as $\mathrm{Na}$ nobryum dummeri), Pursell \& Reese (1980: fig. 1-11), Potier de la Varde (1926: fig. 32a-f as Anisothecium pallidisetum; 1928: fig. 9a-o as Nanobryum dummeri).

Fig. 8. Fissidens gladiolus Mitt. (1-5). 1 - sporophytic stem; 2 - perichaetial stem; 3 - part of perichaetial leaf, distal part of vaginant lamina on the right and vestigial dorsal lamina on the left; 4 - subula of perichaetial leaf; 5 - vaginant lamina of perichaetial leaf with long, narrow cells and ill-defined limbidium. F. magnicellulatus Brugg.-Nann. (6-13). 6-perichaetial stem; 7 - sporophytic stem; 8 - perichaetial leaf; 9 - apex perichaetial leaf; 10 - apex subperichaetial leaf; 11 - termination of the vaginant lamina of mid perichaetial leaf; 12 - basal part vaginant lamina showing the long, narrow cells; 13 - capsule. 1 from Jones 572 (PC-PV); 2 \& 5 from Wigginton U 3109A (L); 3 \& 4 from Assel 416 (PC); 6, 9 \& 11 from Pócs \& Nsolomo 88139/E (EGR 1 broken stem); 7, 8, 10, 12 \&13 from Townsend 75/21 (holotype L). 


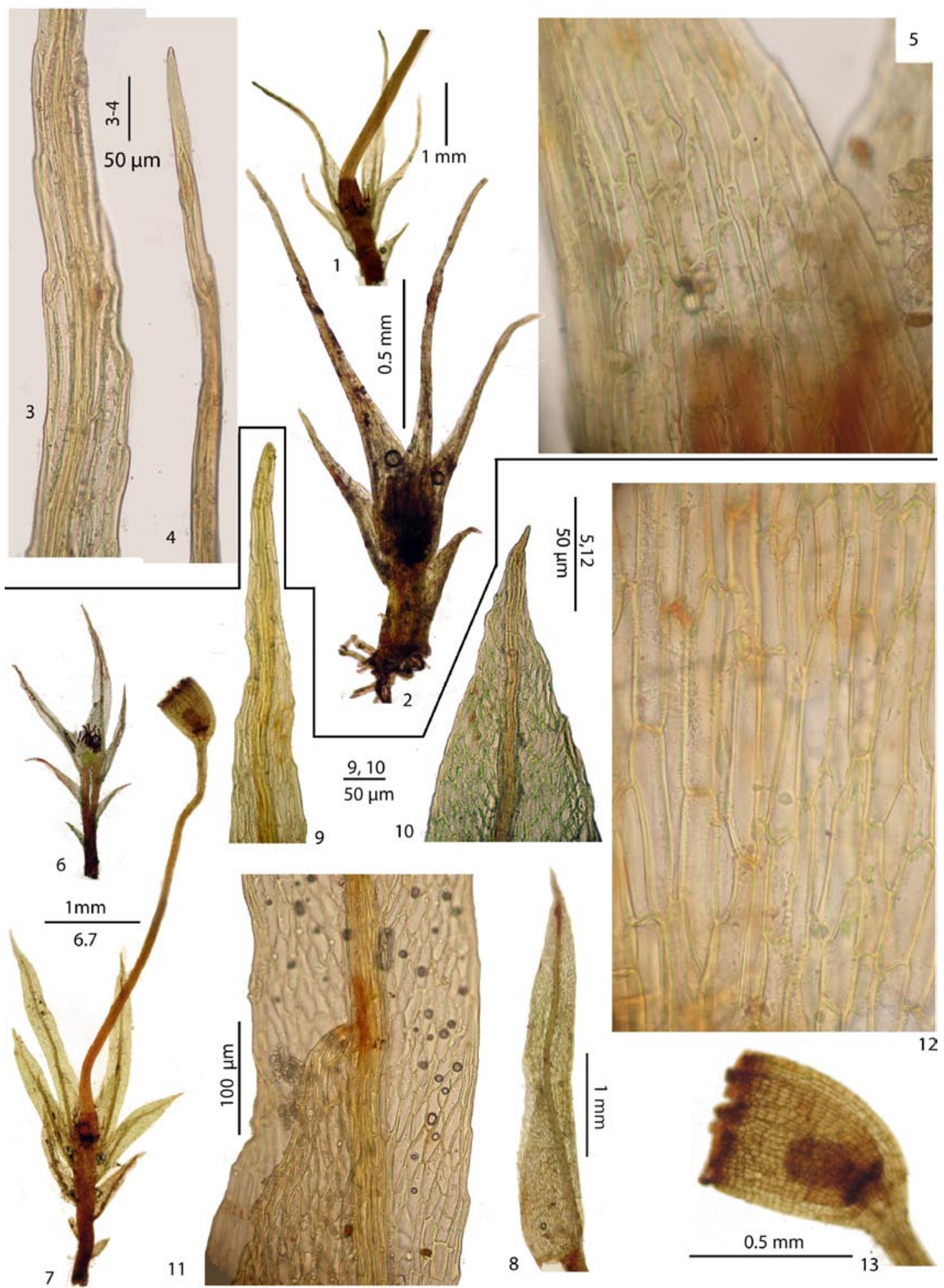


9. Fissidens gomae P. de la Varde \& J.-F. Leroy in J.-F. Leroy

Fig. 9

Bull. Jard. Bot. État Brux. 18: 156, fig. 10. 1947. - TYPE: Democratic Republic of the Congo [Congo belge], sousdistrict de la plaine de lave et des formations sclérophylles. Goma, sur la lave, grande crevasse, mai 1936, Leroy 163 [LECTOTYPE (nov.): BR (mixed with a few F. zollingeri Mont.); ISOTYPE: PC-PV].

Growing in loose mats. Stems mostly unbranched, $2.0-4.0 \times 1.2-1.5 \mathrm{~mm}$, pinnate with distinct, red or colorless central strand; rhizoids basal, pale brown, smooth; axillary cells weakly differentiated; leaves green, distant to close, 9-15 pairs, crispate when dry, oblong, broadly elliptical and oblong-obovate with broadly acute, rounded apiculate or obtuse apiculate apex, $0.50-1.20 \times 0.15-0.40 \mathrm{~mm}, \mathrm{~L} / \mathrm{W}$ $2.5-4$, margin subentire to weakly crenulate where elimbate; limbidium present on all laminae of mid and upper leaves of both perichaetial and vegetative stems, in lower leaves frequently restricted to the vaginant laminae, confluent at the apex of the vaginant lamina or not, reaching the insertion of the vaginant lamina or not; ending well below the leaf apex; frequently ending well above the insertion of the dorsal lamina, in mid dorsal lamina, 4.5-11.0 $\mu \mathrm{m}$ wide, unistratose, rarely locally bistratose; on vaginant lamina unistratose, marginal to intramarginal by 1 row; vaginant lamina 1/2-3/5 the leaf length, closed or slightly open, unistratose; dorsal lamina narrowing and \pm straight to slightly rounded towards the insertion, reaching the insertion, not decurrent; dorsal and apical laminae unistratose; costa ending 1-3 cells below the apex; mid dorsal laminal cells clear, hexagonal, smooth, plane, $8.0-17.5 \times 6.5-11.0 \mu \mathrm{m}$; mid vaginant laminal cells $8.0-24.0 \times 6.5-11 \mu \mathrm{m}$.

Fertile parts. Perigonia, perichaetia and synoicia terminal, less often on short branches from upper part of stem, perigonial stems $3.5 \mathrm{~mm}$ long; antheridia 200-250; synoicial leaves 0.65-
$0.70 \mathrm{~mm}$ long, perichaetial leaves $0.95-1.40 \mathrm{~mm}$ long; archegonia 200-350 $\mu \mathrm{m}$. Sporophyte, seta $2 \mathrm{~mm}$ long, smooth, 1 per perichaetium; capsule symmetrical, $0.75 \times 0.35 \mathrm{~mm}$, with 56 files of oblong exothecial cells; peristome of the bryoides type, at the base 33.5-50.0 $\mu \mathrm{m}$ wide; operculum not seen; calyptra not seen; spores $14.5-18 \mu \mathrm{m}$ long, smooth, pale brownish green.

This species is characterized by its small size, large clear cells, leaves of perichaetial stems and the upper and mid leaves of vegetative stems limbate on all laminae, in lower leaves limbidium often restricted to the vaginant laminae, and by delicate, 1(2) stratose limbidia that end below the leaf apex and above the insertion of the dorsal lamina. Synoicia and perichaetia of Tanzanian collections are often rather lax with the perichaetial and subtending leaves less crowded than in most Fissidens species. In such gametangia the terminal cluster of archegonia (or archegonia plus antheridia) tends to falls apart in several distinct axillary clusters (Fig. 9: $6,7)$. Most Tanzanian specimens, as well as the Uganda specimen, are from places that are periodically inundated or sprayed (e.g., riverine forests, cascades). The type specimen of $F$. gomae, however, was collected in a dry habitat. Morphologically the semiaquatic specimens resemble the type. Fissidens gomae can be taken for a weak $F$. androgynus or a weak F. leucocinctus. Both, however, are more robust and have pluristratose limbidia. Fissidens taylorii and F. bogosicus can be distinguished by their elimbate to poorly limbate leaves.

NOTE. A collection of this species (Jones \& Pócs 6314/E) was earlier recorded as $F$. crassipes var. philibertii Besch. (Bizot \& Pócs 1979: 238).

HABITAT. Tanzania: riverine forests $(4 \times)$, groundwater forest $(1 \times)$, lowland rainforest $(2 \times)$; near waterfall. Several collections are covered by diatoms.

Fig. 9. Fissidens gomae P. de la Varde \& J.-F. Leroy 1 - stem (probably a young perichaetial one before forming of archegonia); 2 - perichaetial stem; 3 - vegetative stem; 4 \& 5 - leaves; 6 - synoicial leaf with 2 axillary synoicial clusters (lower leaf removed); 7 - detail 6; 8 \& 9 - leaf apices; 10 - mid leaf; 11 - basal part of leaf. 1 \& 4 from Pócs \& Ndosi 9001/E (private herbarium Bruggeman-Nannenga); 2, 5-8, 10 \& 11 from Pócs, Minja \& Towo 87202/L (private herbarium Bruggeman-Nannenga); 3 from Van Zanten \& Pócs 86.08.313 (private herbarium Bruggeman-Nannenga); 9 from type F. gomae (BR). Brown coloring 5 by $\mathrm{KOH}$ 5\%. 

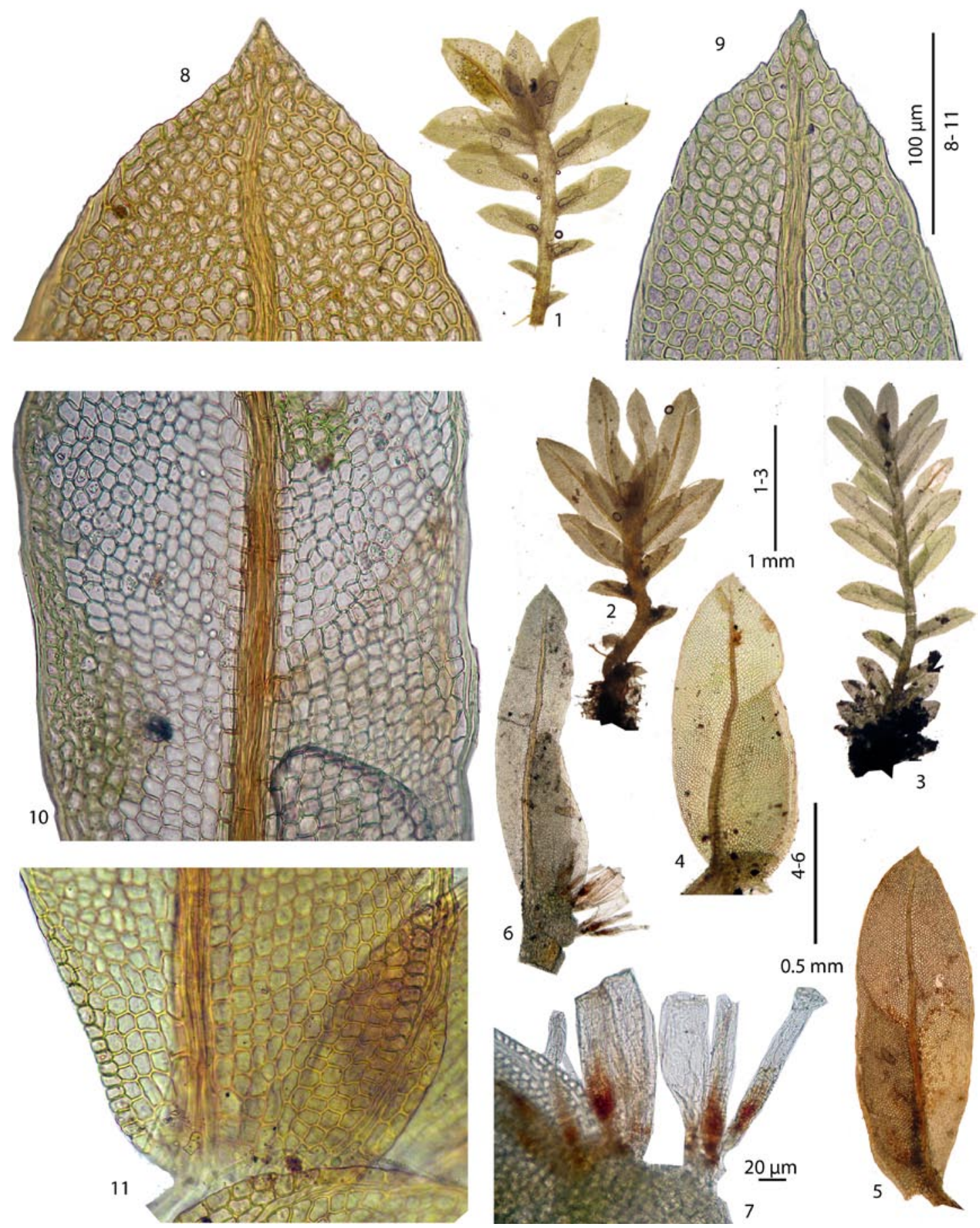
SUBSTRATE. Tanzania: saxicolous (on shady, concrete bridge pillar, on irrigated rocks, on volcanic rocks); less often on soil. In Tanzania the species seems to prefer limestone.

Altitude. 480-1500 m.

DistRIBUTION. African endemic. Known from west-central tropical Africa (Democratic Republic of the Congo, eastern part), and east tropical Africa (Tanzania, Uganda). In Tanzania known from Arusha (Mt. Meru, Tenguru), Dodoma (Usagara Mts), Kilimanjaro (foot of Kilimanjaro Mts), and Morogoro (Mahenge Plateau). New to Uganda.

SPECIMENS EXAMINED: TANZANIA, Arusha, Mt. Meru, Pócs \& Van Zanten 86125/K, p.p. (EGR, L), 86125/O (EGR, L); Tenguru, Van Zanten \& Pócs 86.08.313 (GRO, private herbarium Bruggeman-Nannenga); Dodoma, Usagara Mts, Jones \& Pócs 6314 $/ E$ (EGR, PC); Kilimanjaro, S. foot of Kilimanjaro Mts, Pócs \& Ndosi 9001/E (EGR, private herbarium Bruggeman-Nannenga); Morogoro, Mahenge Plateau, Pócs, Minja \& Towo 87202/L (EGR, private herbarium Bruggeman-Nannenga); Mahenge Scarp forest reserve, Pócs, Minja \& Towo 87207/N, a few stems mixed Fissidens sciophyllus and a few $F$. flaccidus (EGR, private herbarium Bruggeman-Nannenga). - DEMOCRATIC REPUBLIC OF THE CONGO, Goma, Leroy 163 (BR, PC-PV). - UGANDA, Toro District, Lock 88/24 (E, private herbarium Bruggeman-Nannenga).

\section{Fissidens leucocinctus Hampe}

Fig. 10

Linnaea 38: 222. 1874. - TYPE: Madagascar, Borgen 23 (LECTOTYPE designated by Bruggeman-Nannenga 1997: BM; ISOLECTOTYPES: PC, NY both

as Borgen s.n.).

Fissidens crispopachyloma Dixon, J. Bot. 76: 220. 1938. - HolotyPE: Kenya, [Kenya Colony], on rocks, along Massaoia, 20 VIII 1908, Balbo 127 (BM).

Fissidens rutenbergii Paris, Index Bryol. Suppl.: 164. 1900 (new name for $F$. pauperrimus Müll. Hal., Hedwigia 38: 54. 1899, hom. illeg.). - LECTOTYPE (designated by Bruggeman-Nannenga 1993): South Africa [Süd-Africa], Thal nach dem Malappa's place, Juni 1877, Rutenberg s.n. (PC).

Fissidens malaco-bryoides Müll. Hal. var. irriguus P. de la Varde, Rev. Bryol. Lichénol. 25: 213, fig. 2, 16-17. 1956. - HolOTYPE: Uganda, Kapchorwa, Sebei County, alt. $6500 \mathrm{ft}$. Rocks in stream near camp, Lind 128 (PC-PV).
Growing in mats, submerged or not; stem with weak central strand, unbranched or branched, 5-30 $\times 2-3 \mathrm{~mm}$, pinnate; rhizoids basal, a few axillary, bright brown, smooth; axillary nodules not to weakly developed; leaves obscure, close but not overlapping, up to 30 pairs, slightly crispate when dry, elliptical, elliptico-oblong, obovate, broadly acute to obtuse, $0.7-2.6 \times 0.2-0.7 \mathrm{~mm}, \mathrm{~L} / \mathrm{W} 3-4$, limbate on all laminae (young stems and short branches sometimes elimbate on dorsal and apical laminae); limbidium ending well below the apex and above the insertion of the dorsal lamina or becoming indistinct toward the insertion, reaching the insertion of the vaginant lamina, confluent at the apex of the vaginant lamina; in mid dorsal lamina $32-33 \mu \mathrm{m}$ wide, $2-5$ stratose; on vaginant lamina $1-3$ stratose, marginal or intramarginal by one row of cells; vaginant lamina $1 / 2-3 / 5$ the leaf length, slightly open, unistratose, near the costa 1-2 stratose; dorsal lamina abruptly narrowed, narrowing and straight towards the insertion, reaching the insertion, not to indistinctly decurrent, dorsal and apical laminae unistratose with small to large bistratose areas, near costa and border 1-3 stratose, 1-3 stratose at the insertion; costa ending 4-5 cells below the leaf apex; mid dorsal laminal cells obscure, hexagonal, plane and smooth, 6.5$13.5 \times 5.0-9.5 \mu \mathrm{m}$, deep; mid vaginant laminal cells $6.5-11.0 \times 5.0-8.0 \mu \mathrm{m}$; infrequently with rhizoid-like brown files of short cells with transverse cross-walls (gemmae).

Fertile parts, perigonia terminal, perigonial stems $9 \mathrm{~mm}$ tall; antheridia $400 \mu \mathrm{m}$; perichaetia terminal; perichaetial leaves $2.2 \mathrm{~mm}$ long; archegonia $500 \mu \mathrm{m}$ long; sporophyte unknown.

Fissidens leucocinctus is a hydrophilous to rheophilous species that is characterized by broadly elliptical, elliptico-oblong and obovate, limbate leaves; stout limbidia that typically fail well below the leaf apices and well above the insertion of the dorsal lamina; and smooth, plane to slightly convex laminal cells; basal parts of the dorsal lamina are typically pluristratose.

According to the original description it has papillose laminal cells. The type specimen, however, has highly convex, but smooth laminal cells. 

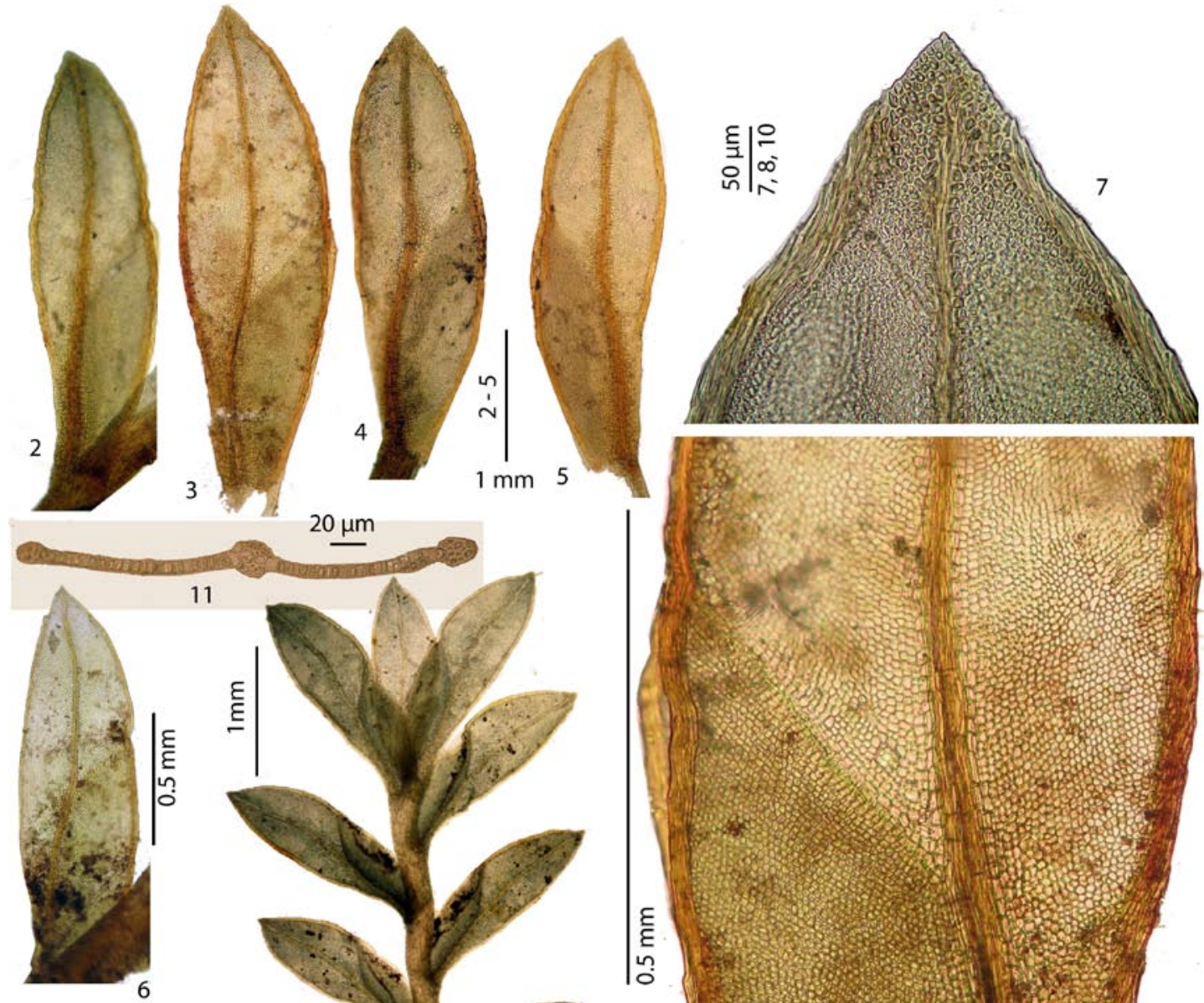

\section{1}
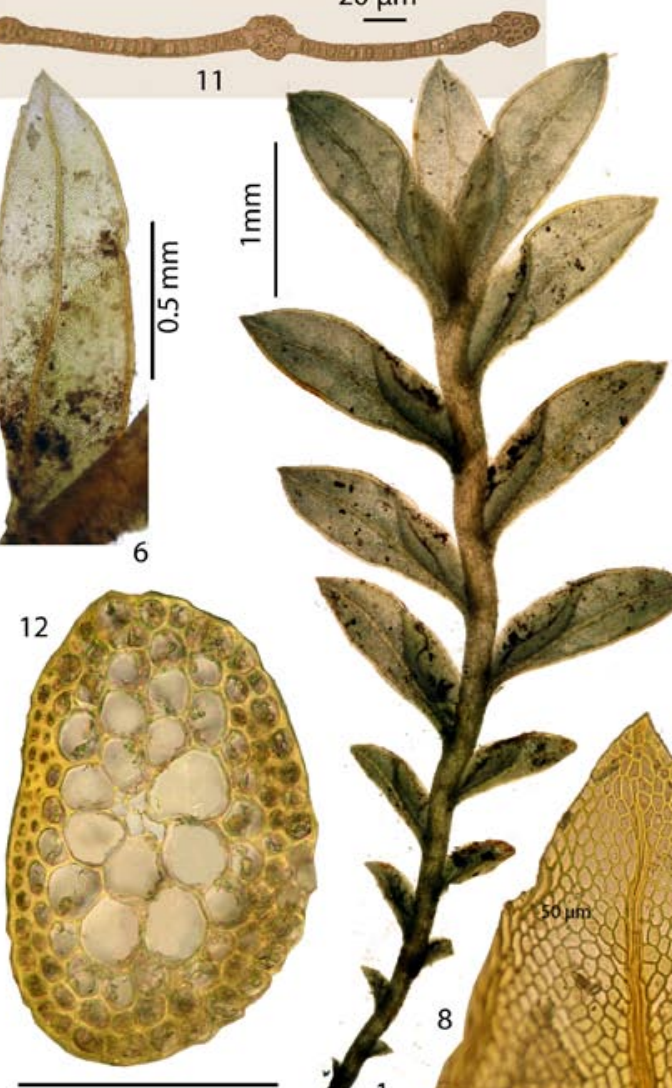

$100 \mu \mathrm{m}$
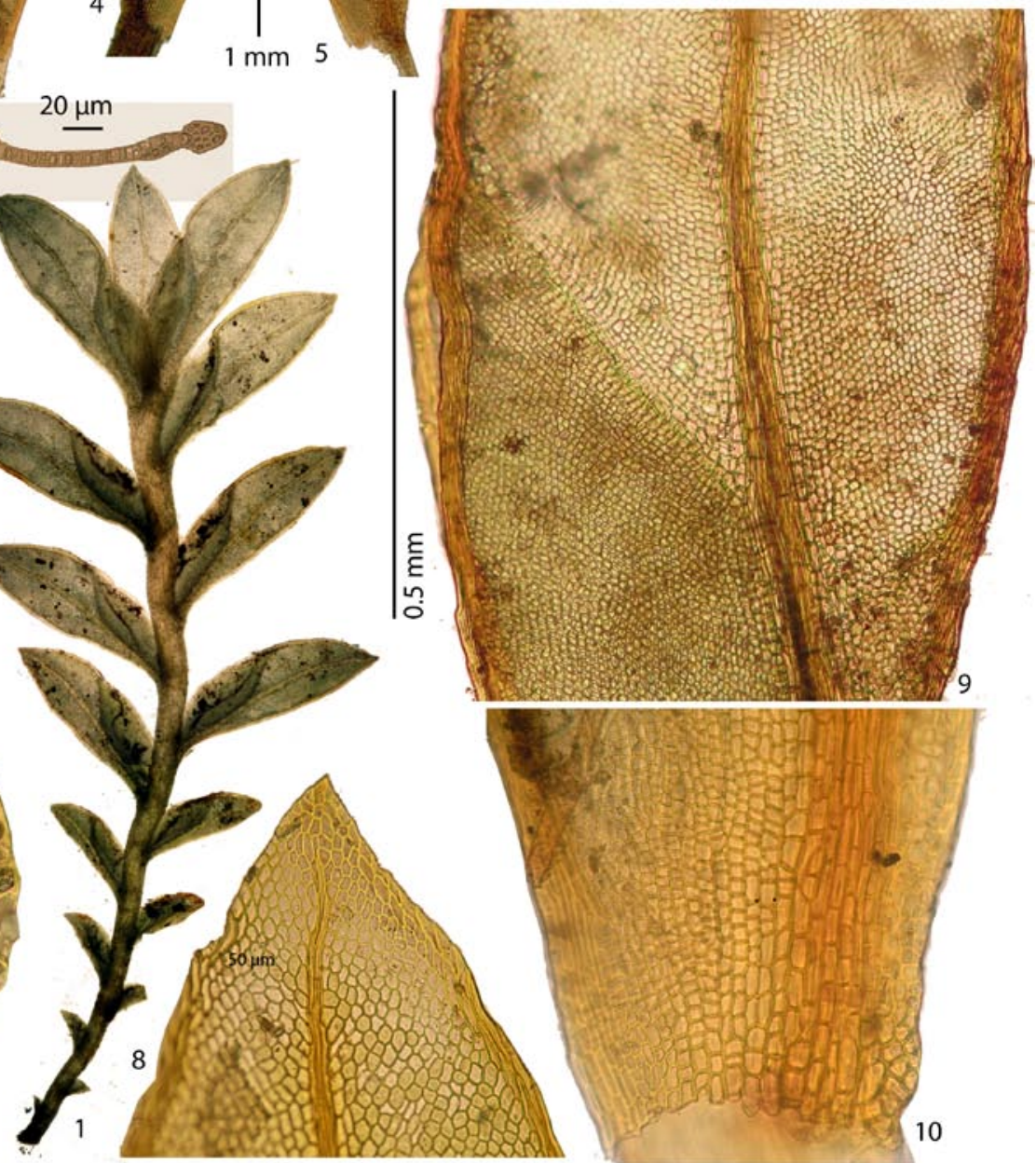

Fig. 10. Fissidens leucocinctus Hampe 1 - vegetative stem; $2-5$ - leaves; 6 - leaf from expression with thin limbidia; 7 - leaf apex; 8 - leaf apex from expression with thin limbidia; 9 - mid leaf; 10 - basal part of leaf; 11 - trans section of leaf above the vaginant lamina; 12 - trans section of stem. 1 from Pócs 90127/A (L); 2-5, 7, 9-12 from Pócs 6208/N (L); 6 \& 8 from Jones \& Pócs 6314/B (PC). 
Fissidens leucocinctus can be confused with $F$. pachylomadelphus which differs by limbidia that nearly or completely reach the insertion of the dorsal lamina and leaf apex. Small expressions can be confused with $F$. obscurifrons which has narrower leaves and poorly developed or lacking limbidia on the dorsal and apical lamina.

Aberrant Collections: Pócs, Minja \& Towo $87202 / A$ is completely encrusted in lime. An expression with atypical thin limbidia (Jones \& Pócs $6314 / B, C$ and $D$ ) was earlier reported as $F$. crassipes var. philibertii Besch. [ $=F$. crassipes subsp. warnstorfii (M. Fleisch.) Brugg.-Nann.] by Bizot \& Pócs (1979). These specimens differ from $F$. crassipes subsp. warnstorfii in their pluristratose basal dorsal laminae. Another collection from the same locality, Jones \& Pócs 6314/E that was also cited as $F$. crassipes var. philibertii Besch. appeared to be $F$. gomae.

HABITAT. Irrigated places, near streams, streamlets and waterfalls; also in irrigation ditches. In riverine forests; primary and secondary lowland and montane rainforests; often submerged.

SuBSTRATE. Saxicolous on basalt, limestone and unspecified rocks; typically on regularly inundated or sprayed rocks, stones and pebbles near streams and waterfalls; rarely on wood (aerial roots) or soil.

Altitude. 0-2100 m.

Distribution. West-central tropical Africa (Cameroon, Democratic Republic of the Congo, Gabon); northeast tropical Africa (Ethiopia); east tropical Africa (Kenya, Tanzania, Uganda); south tropical Africa (Angola, Zambia, Zimbabwe); southern Africa (South Africa); and western Indian Ocean (Comores, La Réunion, Madagascar). Distribution in Tanzania: Arusha (Ngorongoro), Dodoma (Usagara Mts), Kilimanjaro (Kilimanjaro Mts), and Morogoro (Mahenge Plateau). New to Angola.

SPeCimens EXAMINED: TANZANIA, Arusha, Ngorongoro Crater, Pócs \& Chuma 89027/AO (EGR, private herbarium Bruggeman-Nannenga); Dodoma, Usagara Mts, Jones \& Pócs 6314/B, C and D (EGR,
PC); Kilimanjaro, Kilimanjaro Mts, Pócs 6208/N (EGR, L); Pócs, Harrison \& Mushi 90127/A (EGR, private herbarium Bruggeman-Nannenga); and Morogoro, Mahenge Plateau, Mselezi Forest, Pócs, Minja \& Towo 87202/A (EGR, private herbarium BruggemanNannenga). - ANGOLA, Distríto do Cuanza-Sul, Seles, Gossweiler 9 (BM). - DEMOCRATIC REPUBLIC OF THE CONGO, Prov. Kivu, Pócs 6613 (BONN, private herbarium Bruggeman-Nannenga). - ETHIOPIA, $H y$ lander 4417 (private herbarium Bruggeman-Nannenga). - SOUTH AFRICA, Transvaal, Brenan M 3294 (E).

ILLUSTRATIONS: Bruggeman-Nannenga (2006a: fig. 13a-e), Bruggeman-Nannenga \& Arts (2010: fig. 15), Renauld (1909: pl. 37: 1 as F. luridus Renauld \& Cardot).

\section{Fissidens magnicellulatus Brugg.-Nann.}

Fig. 8: 6-13

Lindbergia 36: 13, fig. 2. 2013. - TYPE: Zambia, Lusaka Distr. On damp vertical earth bank in Syzygium thicket by Bothasrus road $8 \mathrm{~km}$ from the Wilfred Watson turnoff from the Lusaka/Mumbwa road, alt. $c a 1275 \mathrm{~m}, 10 \mathrm{II}$ 1975, Townsend 75/21, p.p., mixed with F. bogosicus (HOLOTYPE: private herbarium Bruggeman-Nannenga; ISOTYPE: E).

MisAPPLIED NAME: Fissidens gladiolus BruggemanNannenga (2009).

Growing in mats; vegetative stems unknown; perichaetial stems $2.5-4.0 \times 1.1-3.5 \times 1.3-$ $1.7 \mathrm{~mm}$, unbranched, elongate frondiform, with weak central strand; rhizoids basal, pale brown to hyaline, smooth, a few persistent protonemata; axillary cells not differentiated; leaves close to distant, 4-5 pairs, crispate when dry, lanceolate, narrowly acute, subulate, upper leaves $1.35-2.20$ $\times 0.25 \mathrm{~mm}, \mathrm{~L} / \mathrm{W} 5.5-9.0$, limbate; limbidia on all laminae, reaching the leaf tips and confluent with the costae, reaching the apex of the lesser lamella and confluent with the costa, \pm reaching the base of the dorsal and vaginant lamina, in mid dorsal lamina $15-17 \mu \mathrm{m}$ wide (1-2 stratose?); on vaginant lamina distinct to ill-defined, unistratose, marginal; vaginant lamina (of upper leaves) 1/2-3/5 the leaf length, \pm open, unistratose; dorsal lamina tapering below, \pm reaching the insertion in perichaetial and subperichaetial leaves, ending well above the insertion or lacking all together on mid and lower 
leaves, dorsal and apical laminae unistratose; costa long excurrent, in trans-section anomalous with a variable number of irregularly arranged large cells; mid dorsal laminal cells hexagonal, smooth, plane, 32-60 × 8-15 $\mu \mathrm{m}$; mid vaginant laminal cells $56.0-87.0 \times 14.5-21.0 \mu \mathrm{m}$.

Fertile parts, perigonia terminal on small, $c a$ $0.4 \mathrm{~mm}$ tall, budlike stems at the base of sporophytic stems; perichaetia terminal; perichaetial leaves 1.9-2.2 mm long; archegonia 200-300 $\mu \mathrm{m}$ long. Sporophyte, seta 2.5-5.0 mm long, smooth, 1 per perichaetium; capsule inclined to horizontal, $0.5-0.6 \times 0.4 \mathrm{~mm}, \pm 40(-60)$ columns of thin walled, oblong exothecial cells; peristome bryoides type (only basal OP seen), teeth 40.0 41.5(-55.0) $\mu \mathrm{m}$ wide at base; operculum not seen; calyptra not seen; spores subglobose, $13 \mu \mathrm{m}$ long, probably smooth, green.

Fissidens magnicellulatus is characterized by its large laminal cells, limbate dorsal and apical laminae, long per- to excurrent costae and \pm open vaginant laminae. In several respects it is similar to $F$. gladiolus. Both have laminal cells that are large for the subgenus and stout, long ex- to percurrent costae, long, narrow inner vaginant laminal cells, poorly developed to lacking dorsal and apical laminae in mid and lower leaves, strongly inclined capsules and bryoides type peristomes. Both are known only from fertile stems. They can be separated by the perichaetial and subperichaetial leaves which have well developed apical and dorsal laminae in F. magnicellulatus, whereas in $F$. gladiolus they are at best weak and narrow, or often lacking altogether. Moreover, F. gladiolus has longer subulae. In Tanzania known from a single stem. Fissidens magnicellulatus can also be confused with $F$. beckettii Mitt. This species also has open vaginant laminae and strongly inclined capsules but differs by its smaller, relatively wider laminal cells (mid dorsal laminal cells 12.0-22.5 $\times 6.0-12.0 \mu \mathrm{m}$; mid vaginant laminal cells 16.0 $\times 8.0-9.5 \mu \mathrm{m})$ and in having distinct limbidia on the vaginant laminae.

HABITAT. On damp vertical earth bank in Syzygium thicket and in a dry evergreen forest.
SUBSTRATE. Soil and bark.

ALTITUDE. 1275-2000 m.

Distribution. Zambia, Tanzania. Rare. New to Tanzania.

SPECIMENS EXAMINED: TANZANIA, Arusha, Meru Mts, Pócs \& Nsolomo 88139/E (EGR 1 broken stem). - ZAMBIA, Townsend 75/21 (E, private herbarium Bruggeman-Nannenga).

NOTE. To make comparison of the two species easier the figures of the present species are in the same figure as those of $F$. gladiolus.

\section{Fissidens megalotis Schimp. ex Müll. Hal.}

Bot. Zeitung (Berlin) 16: 15. 1858. - TYPE: South Africa, Prom. Bonae spei, Groenekloof, Breutel s.n. (HOLOTYPE: BM, ISOTYPE: PC).

This species is characterized by crispate stems and leaves, more or less open vaginant laminae, small, bulging laminal cells, limbidia that are typically intralaminal on the vaginant laminae and decurrent dorsal laminae.

\section{KEY TO THE SUBSPECIES}

1. Vaginant lamina typically nearly or completely open, margin of vaginant laminae often serrate . . . . . . . $\ldots \ldots \ldots \ldots \ldots$. megalotis subsp. megalotis 1. Vaginant lamina slightly open, margin of vaginant lamina entire ...................... $\ldots \ldots \ldots \ldots$ F. megalotis subsp. helictocaulos

\section{F. megalotis subsp. megalotis}

Fissidens megalotis subsp. megalotis is found in southern Africa, Australia and New Zealand, whereas subspecies helictocaulos has a more northern exclusively African distribution.

F. megalotis subsp. helictocaulos (Müll. Hal.) Brugg.-Nann.

Fig. 11

J. Hattori Bot. Lab. 81: 163. 1997. Fissidens helictocaulos Müll. Hal., Bot. Zeitung (Berlin) 22: 341. 1864. - LECTOTYPE (designated by Bruggeman-Nannenga 1997): Ethiopia, [Abyssinia], Amba Sea, 6000 ft., 8 September 1847, Schimper s.n. (as F. schimperi/ helictocaulos) (PC). 
Fissidens pseudorufescens Müll. Hal., Flora 62: 376. 1879. - LECTOTYPE (designated by Bruggeman-Nannenga 1997): Kenya, [Ost-Afrika], Ndâra (Taita), Hildebrandt s.n. (BM).

Fissidens latifolius Dixon, S. African J. Sci. 18: 305. 1922. - LECTOTYPE (designated by Bruggeman-Nannenga 1997): Zimbabwe, alt. 3000 ft, Sim 8766 (BM).

Fissidens vesiculosus Demaret \& J.-F. Leroy, Explor. Parc Natl. Albert, Mission Lebrun (1937-1938) 6: 5. F. 1-4. 1944. - TYPE: Democratic Republic of the Congo, Parc national Albert, Lac Mungunga. Berges rocheuses, alt. 1500 m, XI 1937, Lebrun 8826 (HOLOTYPE: BR not seen; ISOTYPE: PC-PV).

Only synonyms from tropical eastern Africa are listed.

Usually growing in large mats; rhizoids basal and axillary, bright to pale brown, smooth; axillary cells not to weakly differentiated; stem with well-developed central strand, pinnate, simple or branched, branches frequently arising from stem apex, 0.8-7.0 (10.0 mm including branches) $\times$ $1.5-2.0 \mathrm{~mm}(2.5 \mathrm{~mm}$ in perichaetium); leaves green to brown, strongly crispate when dry, hardly flattening in water, more or less flattening in $5 \% \mathrm{KOH}$, distant to crowded, up to 17 pairs, oblong-lanceolate to oblong to ovate-lanceolate, broadly acute to rounded obtuse, acute-acuminate to obtuse mucronate, $0.9-1.4 \times 0.3-0.5 \mathrm{~mm}, \mathrm{~L} / \mathrm{W}$ 2.5-5.0, limbate; limbidium reaching the leaf apex to ending 3-4 cells below, not confluent with the costa; reaching the insertion of the vaginant lamina or ending well above, reaching the apex of the smaller lamella of the vaginant laminae, but not confluent with the limbidium of the other lamella; reaching the insertion of the dorsal laminae or not, in mid dorsal lamina 7.5-9.5 $\mu \mathrm{m}$ wide, 1-2 stratose; on vaginant lamina $1-2$ stratose, in the basal part of the vaginant lamina intramarginal by $1-5$ cells rows, often marginal in some leaves; vaginant lamina $1 / 3-3 / 5$ the leaf length, slightly to half open (in perichaetial leaves open), gaping, unistratose; dorsal lamina wide and rounded or wide and tapering towards the insertion, reaching the insertion, frequently long decurrent; dorsal and apical laminae unistratose or with some bistratose dots; costa per- to excurrent, in trans-section asymmetrical (i.e., better developed in the larger lamella of the vaginant lamina); mid dorsal laminal cells round-hexagonal, convexly to lenticularly thickened, smooth, 4.5-8.0 $\times 3.0-6.5 \mu \mathrm{m}$; mid vaginant laminal cells, $6.5-9.5 \times 6.5 \mu \mathrm{m}$.

Fertile parts. Perigonia not observed; perichaetia terminal, perichaetial leaves $1.7-2.4 \mathrm{~mm}$ long, archegonia 300-500 $\mu \mathrm{m}$ long. Sporophyte, seta 4.5-8.0 mm long, smooth, 1-2 per perichaetium; capsule inclined to strongly inclined or curved, $0.65-0.85 \times 0.35-0.50 \mathrm{~mm}, 40-56$ columns of oblong exothecial cells; peristome bryoides type, tooth base 50-53 $\mu \mathrm{m}$ wide; operculum rostrate, $0.3 \mathrm{~mm}$ long; calyptra not observed; spores 16-24 diam., smooth, green.

Fissidens megalotis subsp. helictocaulos is characterized by its slightly open, gaping vaginant lamina with the limbidium of the smaller lamella ending on the lamina and not confluent with that of the larger lamella; intramarginal limbidia on the vaginant laminae of some or all leaves; and small, highly convex, thick walled laminal cells. Also characteristic are vaginant laminal lamellae that form a \pm continuous blade with the apical laminae to which the smaller vaginant laminal lamellae seem to be obliquely attached. This is also expressed in the anatomy of the costa in which one of the two large central cells (a) and the right adaxial cell (b) make a more or less straight line connecting the right lamella of the vaginant lamina (c) and the dorsal lamina (d) (Fig. 11: 9, 9a). For a trans section of a symmetrical bryoides type costa see Fig. 16: 9. In 5\% KOH the leaves first turn yellowish-green then bright orange-brown. Fissidens

Fig. 11. Fissidens megalotis subsp. helictocaulos (Müll. Hal.) Brugg.-Nann. 1 - short perichaetial stem; 2-4 - leaves; 5 - leaf apex; 6 - mid leaf; 7 - insertion of dorsal lamina; 8 - insertion vaginant lamina with intramarginal limbidium; $9 \& 9 a-$ trans section of asymmetrical costa ( $\mathrm{a}$ - large central cell; $\mathrm{b}$ - large adaxial cell; $\mathrm{c}$ - larger vaginant laminal lamella; $\mathrm{d}$ - dorsal lamina); 10 - bifurcations of peristome teeth (bryoides type). 1-3 from Kis \& Pócs 9104/L (L); 4, 5, 7-9 from Pócs \& Nsolomo 89192/H (private herbarium Bruggeman-Nannenga); 6 from Pócs \& Chuwa 89023/J (private herbarium Bruggeman-Nannenga); 10 from Pócs 8678/R (private herbarium Bruggeman-Nannenga). 

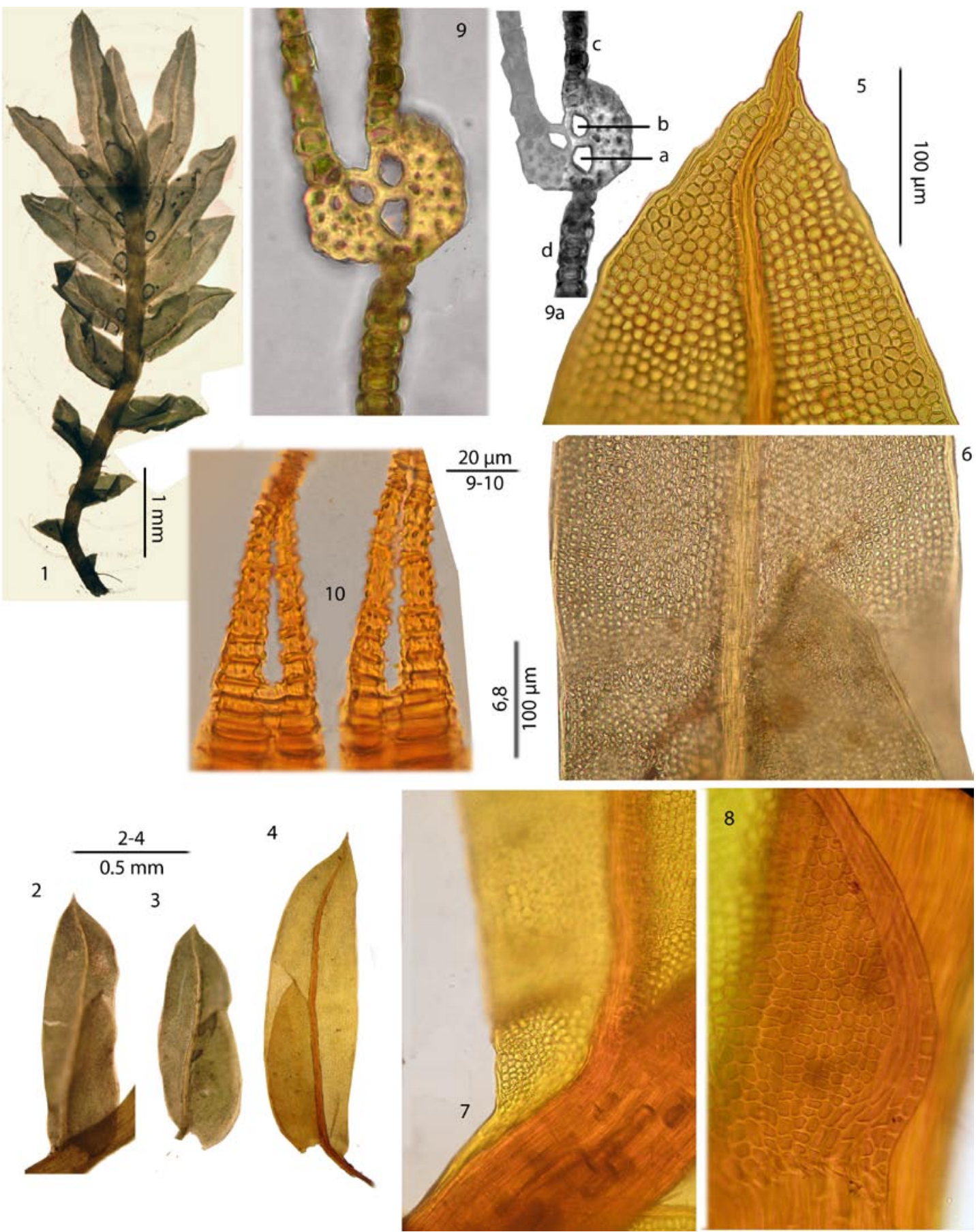
megalotis subsp. helictocaulos can be confused with $F$. artsii, $F$. crispus and $F$. androgynus which all differ by their closed vaginant laminae. From subsp. megalotis it differs by vaginant laminae that are slightly but not completely open, entire vaginant laminal margins, less strongly crispate leaves and limbidia that are intramarginal by fewer cell rows.

HABITAT. Found in a wide variety of wet, humid and dry habitats, natural as well as secondary and cultivated. In spray zone of falls $(2 \times)$, plantations and gardens $(6 \times)$, in forests (riverine forest $(4 \times)$, groundwater forest $(2 \times)$, montane rain forest $(1 \times)$, submontane rainforest $(2 \times)$, montane evergreen forest on $\mathrm{N}$ slope dominated by Olea africana and Cassipourea malosana $(1 \times)$, submontane evergreen forest $(1 \times)$, Hagenia forest $(1 \times)$, microphyllous dry evergreen forest $(1 \times)$, dry evergreen forest $(5 \times)$, dry semi-evergreen forest $(1 \times)$, dry semi-deciduous forest $(5 \times)$, savanna bos $(1 \times)$; further in bushes etc. (secondary bush $(2 \times)$, secondary evergreen bush, slope with succulents and Velloziaceae bushes $(1 \times)$, Catha edulis bush, xeric type $(1 \times)$, and semi-desert scrub and dry rocky grassland $(1 \times)$. This species is probably the most drought-tolerant species in this paper.

SUBSTRATE. Mostly rupicolous, frequently on soil, rarely lignicolous. Rupicolous without further indication $(6 \times)$, rupicolous on shady/half shady rocks and stones $(10 \times)$; on lava/volcanic rocks $(5 \times)$, on gneiss $(3 \times)$, on dry rocks $(1 \times)$; on irrigated or wet rocks $(2 \times)$; on brick drains $(1 \times)$; on earth covered rocks $(2 \times)$; terricolous without further indication $(12 \times)$; on shady soil $(5 \times)$ and lignicolous: on roots $(2 \times)$ and once on bark. Substrate from outside Tanzania: termite hill (Zambia, Townsend 75/187 (E).

Altitude. 0-2900 m.

Distribution. Widespread in Africa, most common in the eastern part. Known from Macaronesia (Cape Verde Islands); west-central tropical Africa (Cameroon, Democratic Republic of the Congo); east tropical Africa (Kenya, Tanzania, Uganda); south tropical Africa (Malawi, Zambia, Zimbabwe); northeast tropical Africa (Eritrea,
Ethiopia, Somalia, Sudan); and western Indian Ocean (La Réunion, Socotra). In southern Africa it is replaced by F. megalotis subsp. megalotis. Wide-spread and common in Tanzania. Distribution in Tanzania: Arusha (Babati District, Longido Hill, Mbulu Highlands, Monduli Mts, Mt. Meru, Ngorongoro, Tenguru), Iringa (Livingstone Mts), Kilimanjaro (Kilimanjaro Mts, Moshi, South Pare), Mbeya (Mbeya District), Morogoro (Morogoro Town, Ukaguru Mts, Uluguru Mts, Nguru), and Tanga (Mafi Hill, West Usambara Mts).

SPECIMENS EXAMINED: TANZANIA, Arusha, Babati District, Pócs 90026/E, F (EGR, private herbarium Bruggeman-Nannenga); Pócs \& Linden 90086/K (EGR, private herbarium Bruggeman-Nannenga); Longido Hill, Pócs et al. 8693/U, V (EGR, L);Pócs \& Nsolomo 88169/L (EGR, L); Pócs \& Nsolomo 89192/H (EGR, private herbarium Bruggeman-Nannenga); Mbulu Highlands, Pócs 90096/ACD (EGR, private herbarium Bruggeman-Nannenga); Sharp et al. $879 B$ (EGR, private herbarium Bruggeman-Nannenga); Sharp, Gilbert \& Suso 8809/A and 9786 (both EGR, L); Van Zanten \& Pócs 86.08.312 (GRO); Whitehouse 26138 (MO, L), 26182 (MO) and 26138 (MO, L); Monduli Mts, Pócs et al. 88160 (KRAM, private herbarium Bruggeman-Nannenga); Mt. Meru, Pócs 8678/P, Q, R, $S, U$ (EGR, L); Pócs \& Van Zanten 86125/L (EGR, L), $86125 / M$ and $Q$ (both EGR, private herbarium Bruggeman-Nannenga; Pócs 88141/A (EGR, private herbarium Bruggeman-Nannenga); Pócs $88166 / O$ and $/ P$ (both EGR, private herbarium Bruggeman-Nannenga) and Q (EGR, L), Pócs \& Nsolomo 89183/AA, AE, $A F$ (EGR, private herbarium Bruggeman-Nannenga); Ngorongoro, Pócs \& Chuwa 88280/V (EGR, private herbarium Bruggeman-Nannenga), Pócs 89010/AE (EGR, private herbarium Bruggeman-Nannenga); Pócs \& Chuwa 89023/J (EGR, private herbarium BruggemanNannenga); Pócs \& Chuwa 89031/AN (EGR, private herbarium Bruggeman-Nannenga); Pócs 89036/K, L, $M, N$ (EGR, private herbarium Bruggeman-Nannenga); Tenguru, Van Zanten \& Pócs 86.08.318 (GRO, private herbarium Bruggeman-Nannenga); Iringa, Livingstone Mts, Iversen et al. 87136/D (EGR, private herbarium Bruggeman-Nannenga); Kilimanjaro, Kilimanjaro Mts, Pócs 88048/U (EGR, private herbarium BruggemanNannenga); Pócs 90051/F (EGR, private herbarium Bruggeman-Nannenga); Pócs 90069/D (EGR, private herbarium Bruggeman-Nannenga); Pócs 90070/D (EGR, private herbarium Bruggeman-Nannenga); Moshi, Pócs 8672/H (EGR, L); Sharp et al. 7059 (EGR, L); South 
Pare Mts, Pócs et al. 89244/A (EGR, private herbarium Bruggeman-Nannenga); Pócs et al. 89247/A (EGR); Pócs et al. 90077/AA, Y (EGR, private herbarium Bruggeman-Nannenga); Mbeya, Mbeya District, Pócs, Farkas, Krog 89127/A (EGR, private herbarium Bruggeman-Nannenga); Townsend 75/339 (E, private herbarium Bruggeman-Nannenga); Morogoro, Morogoro town, Pócs et al. $8675 / G$ (EGR, L); Nguru Mts, Kis \& Pócs 9103/B and 9104/L (both EGR, L); Ukaguru Mts, Pócs et al. 8699/K (EGR, private herbarium Bruggeman-Nannenga); Uluguru Mts, Pócs 8663/ N (EGR, L); S. Uluguru Mts, Mindu Hill, Pócs \& Ochyra 88100/C (EGR, private herbarium Bruggeman-Nannenga); Tanga, Mafi Hill, Pócs 8525/C (EGR); West Usambara Mts, Borhidi 8543/D (EGR, L); Pócs 8436/AB (EGR, L); Pócs et al. 88115/ F (EGR, L); Pócs \& Ochyra 88115/ $J, M$ (EGR, private herbarium Bruggeman-Nannenga); Pócs et al. 88116/C (EGR, private herbarium Bruggeman-Nannenga); 88116/ E (EGR, KRAM, private herbarium Bruggeman-Nannenga).

ILLUSTRATIONS: Kürschner (1999: figs 1-5), Bruggeman-Nannenga (2006b: fig. 14), Bruggeman-Nannenga \& Arts (2010: fig. 16), Demaret \& Leroy (1944: figs $1-4$ as $F$. vesiculosus), Potier de la Varde (1943: 241: fig. 1 as F. alatus P. de la Varde), Tongiorgi (1938: 220 as $F$. badoglioi Tongiorgi).

\section{Fissidens obscurifrons Brugg.-Nann.}

Fig. 12

Polish Bot. J. 58(1): 118, fig. 2. 2013. - TYPE: Tanzania, Nguru Mts, Kanga Forest Reserve, on the SE slope of Mt. Kanga. Lowland rainforest, on irrigated rocks under small waterfall. $700-800 \mathrm{~m}$. 4 December 1987, Pócs, Nsolo \& Temu 87226/AL (HOLOTYPE: L; ISOTYPE: EGR).

Growing from a dense mat of rhizoids, thalloid protonemata (Fig. 12: 11) present or not; stem with weak or lacking central strand, unbranched, 1.5$3.5 \times 0.8-1.7 \mathrm{~mm}$, pinnate; rhizoids basal, bright brown, smooth, up to $33 \mu \mathrm{m}$ wide; axillary cells weakly differentiated; leaves distant to close, up to 13 pairs, hardly altered when dry, obscure, elliptical, elliptico-lanceolate and oblanceolate, acute, $0.5-1.0 \times 0.1-0.6 \mathrm{~mm}, \mathrm{~L} / \mathrm{W} 3-9$, margin subentire, partly limbate; limbidium mostly restricted to the vaginant lamina and basal part (up to $150 \mu \mathrm{m}$ ) of the apical lamina, on dorsal laminae lacking or represented by a few cells in the mid part; on mid of dorsal lamina $0-16 \mu \mathrm{m}$ wide, unistratose; on the vaginant lamina unistratose, marginal or intramarginal; vaginant lamina $1 / 2-3 / 5$ the leaf length, closed to slightly open, unistratose; dorsal lamina narrow, hardly rounded at the insertion, reaching the insertion, not decurrent, dorsal and apical lamina unistratose with scattered bistratose dots, 1-2 stratose alongside the costa and near the insertion; costa ending 5-7 cells below the leaf apex; mid dorsal laminal cells hexagonal, 5.0-11.5 $\times 5.0-8.0 \mu \mathrm{m}$, smooth; mid vaginant laminal cells 6-13 × 3-8 $\mu \mathrm{m}$. Fertile parts unknown.

This species is known by its vegetative state only. It is characterized by narrow, obscure, elliptical, elliptico-lanceolate to oblanceolate leaves; limbidia extending the length of the vaginant laminae and up to $150 \mu \mathrm{m}$ onto the apical laminae; dorsal laminae frequently elimbate. Leaves of poorly developed stems poorly limbate to elimbate. Fissidens obscurifrons could be taken for a small $F$. leucocinctus. Both species grow in places that are frequently inundated and have leaves that are attenuated below. Fissidens leucocinctus can be separated by its larger, wider (L/W 3-4) leaves, stout 3-5 stratose limbidia that are present on all laminae of all leaves and its longer stems (5-30 $\times 2-3 \mathrm{~mm}$ ). Fissidens bogosicus and F. taylorii resemble $F$. obscurifrons in their incompletely limbate leaves but are not aquatic (for more differences see key).

ECOLOGY. Saxicolous on shady rocks, sprayed or irrigated rocks. Near waterfalls and in riverine and lowland rainforests.

Altitude. 700-1000 m.

Distribution. Tanzania, Kilimanjaro (S-Pare Mts) and Morogoro (Nguru Mts).

SPECIMENS EXAMINED: TANZANIA, S-Pare Mts, Pócs 6716/J (EGR, L); Nguru Mts, Pócs, Nsolo \& Temu 87226/AL (EGR, L).

\section{Fissidens pachylomadelphus Demaret}

\& P. de la Varde

Fig. 13

Bull. Jard. Bot. État Brux. 27: 758, fig. 79. 1957. - TYPE: Democratic Republic of the Congo, Distr. des Lacs Edouard et Kivu, Ruwenzori, Kyandolire, casacade de la Mulaka, alt. $1750 \mathrm{~m}$, roche périodiquement inondée 

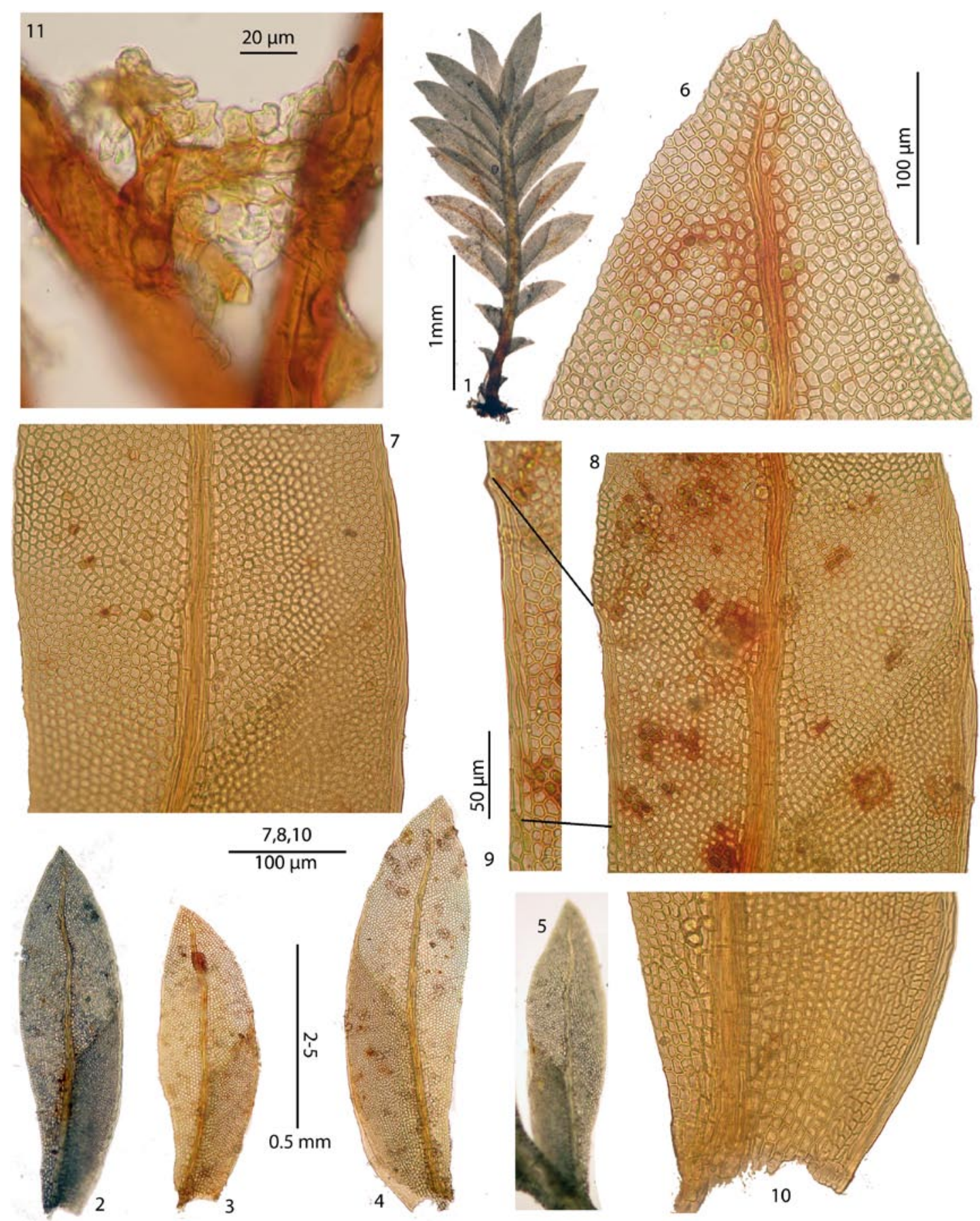

Fig. 12. Fissidens obscurifrons Brugg.-Nann. 1 - vegetative stem; 2-5 - leaves; 6 - leaf apex; 7 - mid leaf with elimbate dorsal lamina; 8 - mid leaf with weakly limbate dorsal lamina; 9 - detail of 8 showing the limbidium; 10 - basal part of leaf; 11 - rhizoids with thalloid protonemata; 1, 5-7 from Pócs, Nsolo \& Temu 87226/AL (holotype L); 2-4, 8-11 from Pócs 6716/J (paratype L) (the same figures were used in the protologue); brown coloring in 3, 4 \& $6-10$ is caused by $5 \% \mathrm{KOH}$. 
dans le torrent, Juin 1953, Demaret 5997 (LECTOTYPE designated by Bruggeman-Nannenga 1993: BR; ISOTYPE: PC-PV).

Rheophilous, firmly attached, in tufts; stems branched or not, 3.0-6.0 × 1.2-2.0 mm, pinnate, central strand present or not; rhizoids basal, brown and smooth; axillary cells not to weakly differentiated; leaves green, distant, slightly overlapping, up to 10 pairs, slightly crisped when dry, lanceolate to oblong, acute-acuminate to bluntly mucronate, $0.50-0.60 \times 0.15-0.17 \mathrm{~mm}, \mathrm{~L} / \mathrm{W} 3-5$, limbate; limbidium stout, reaching the leaf apex and confluent with the costa or ending well below the apex; confluent at the apex of the vaginant lamina, reaching the insertions of the vaginant and dorsal laminae; in mid of dorsal lamina $27 \mu \mathrm{m}$ wide, 1-4 stratose; on the vaginant lamina 1-2 stratose, marginal; vaginant lamina $\pm 1 / 2$ the leaf length, closed, unistratose; dorsal lamina slightly rounded towards the insertion, straight in the basal-most part, reaching the insertion, not decurrent; dorsal and apical laminae unistratose, dorsal lamina at the insertion 1-4 stratose; costa per- to excurrent, cross section above the vaginant laminae with 1 row of 2(-4) large cells; mid dorsal laminal cells clear, oblong-hexagonal, plane, 9.5-14.5 $\times$ 5.5-9.5 $\mu \mathrm{m}$; mid vaginant laminal cells $14.5-17.5$ $\times 6.5-9.5 \mu \mathrm{m}$.

Fertile parts, perigonial and perichaetial stems in same collection, perigonia terminal on ca $4 \mathrm{~mm}$ long stems; antheridia 320-350 $\mu \mathrm{m}$ long; perichaetia terminal; perichaetial leaves $1.9 \mathrm{~mm}$ long with long excurrent costae; archegonia $350 \mu \mathrm{m}$ long; sporophyte, seta 4.5-6.0 mm long, smooth; capsule symmetrical, $0.75 \times 0.50 \mathrm{~mm}, \pm 60$ columns of oblong exothecial cells; peristome bryoides type, teeth 56-65 $\mu \mathrm{m}$ wide at base; operculum rostrate, $0.5 \mathrm{~mm}$ long; calyptra not seen; spores subglobose to distinctly ellipsoid, $16-12 \mu \mathrm{m}, \pm$ smooth.

This rheophilous, saxicolous species has stout limbidia, dorsal laminae with pluristratose basal parts and weakly developed or lacking central strands. Rheophilous species sometimes have astomatose capsules. In the present species stomata were present in at least one capsule. Fissidens pachylomadelphus resembles the variable
$F$. androgynus and in 1993 I synonymized the two (Bruggeman-Nannenga, 1993). However, F. androgynus is not rheophilous, has well developed central strands and dorsal lamina with unistratose basal parts. Fissidens pachylomadelphus further resembles other rheophilous subgenus Fissidens species with stout limbidia, e.g., F. rivularis from Europe, northern Africa, Turkey and Azerbaydzhan. The latter can be distinguished by its axillary antheridial buds (next to which a few terminal antheridia can occur).

ECOLOGY. Saxicolous, in spray-zone of cascades and in periodically inundated places in rivers and streamside rainforests.

Altitude. 1750-2400 m.

Distribution. Democratic Republic of the Congo (Rwenzori [Ruwenzori] Mts), Rwanda (Pref. de Cyangugu) and Tanzania (Nguru Mts). Rare. New to Tanzania

SPECIMENS EXAMINED: TANZANIA, Nguru Mts, Kis \& Pócs 9129/BY (EGR) and Kis \& Pócs 9136/N (EGR, L). - DEMOCRATIC REPUBLIC OF THE CONGO, Demaret 5997 (BR, PC-PV). - RWANDA, Frahm 6203 (BONN, private herbarium BruggemanNannenga).

ILLUSTRATION: Demaret \& P. de la Varde (1957: fig. 79).

\section{Fissidens robynsianus $\mathrm{P}$. de la Varde}

Fig. 14

Bull. Jard. Bot. Etat Brux. 27: 757, fig. 78 a-d. 1957. - TYPE: Democratic Republic of the Congo, Distr. des Lacs Edouard et Kivu, tributary of the Mososa river, rocks in waterfall, alt. $3180 \mathrm{~m}$, Demaret 5257 (HOLOTYPE: BR; ISOTYPE PC-PV).

Growing in mats or tufts, firmly attached to the substrate, tufts blackish when old with pale green fresh shoots; stem with central strand, unbranched or rarely branched, $3.5-10.0 \times 0.4-1.0 \mathrm{~mm}$, pinnate; rhizoids basal, a few axillary, brown, smooth, to $48 \mu \mathrm{m}$ wide (sometimes wide, brown, short celled with transverse cross-walls); axillary nodules not to weakly differentiated; leaves close to distant, up to 27 pairs, hardly altered when dry, lanceolate, elliptico-lanceolate to linear-oblong, linear- 


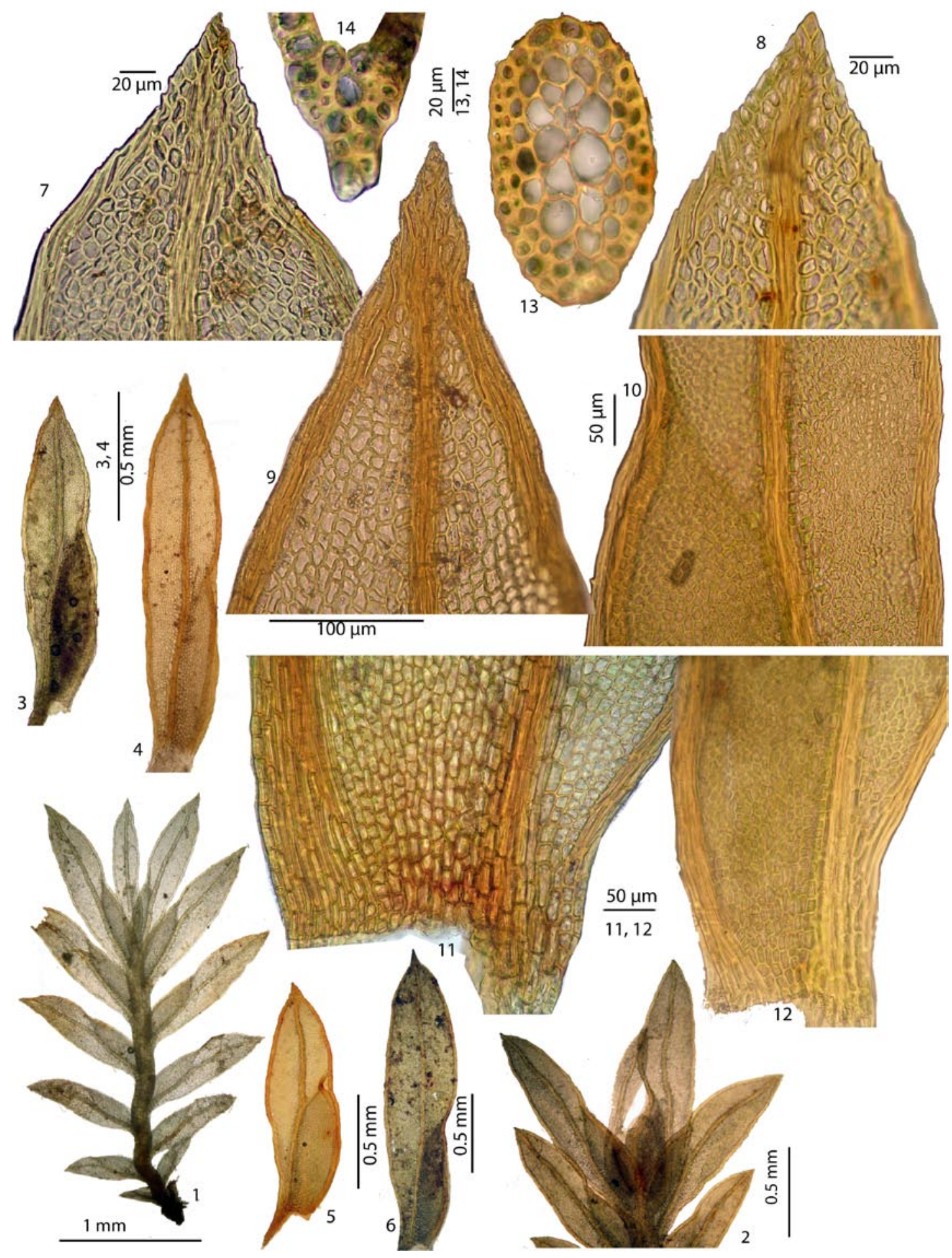


lanceolate or linear-oblanceolate, acute, $0.5-1.5 \times$ 0.1-0.3 mm, L/W 3.5-6, margin typically limbate, subentire where elimbate; limbidium variable, typically on all laminae of all leaves, rarely restricted to the vaginant lamina; ending well below the leaf apex, reaching the insertion of vaginant lamina and confluent at its apex; reaching the insertion of the dorsal lamina or ending well above it, on the mid dorsal lamina infrequently branched, marginal or rarely intramarginal by one row of cells, 7.5-24.0 $\mu \mathrm{m}$ wide, $1-5$ stratose; on the vaginant lamina 1-3 stratose, marginal or intramarginal by 1-2 rows of cells; vaginant lamina $2 / 3-7 / 10$ the leaf length, closed, in perichaetial leaves open, unistratose, near the costa 1-2 stratose; dorsal lamina in the basal 1/5-7/10 part narrow and limbidioid, reaching the insertion or not, not decurrent; dorsal and apical laminae unistratose, sometimes bistratose alongside the costa, rarely a few small dots in the mid lamina; limbidioid part of dorsal lamina to 6 stratose; costa ending 1-5 cells below the leaf apex to percurrent; mid dorsal laminal cells clear, hexagonal, smooth, \pm plane, 6.0-14.5 $\times$ 5.0-9.5 $\mu \mathrm{m}$; mid vaginant laminal cells $5.0-14.5$ $\times 5.0-8.5 \mu \mathrm{m}$.

Fertile parts, perigonia and perichaetia on separate stems; perigonia terminal on $\pm 2 \mathrm{~mm}$ long stems, on branches and in perigonial buds; antheridia $200-340 \mu \mathrm{m}$ long; perichaetia terminal on stems and branches, female stems often shorter than sterile stems, $2.5-3.5 \times 1.0-1.5 \mathrm{~mm}$; perichaetial leaves up to $1.8 \mathrm{~mm}$ long, dorsal laminae of (sub)perichaetial leaves in basal part or over almost their whole length limbidioid, apical laminae partly limbidioid or not; archegonia 350-500 $\mu \mathrm{m}$ long; sporophyte unknown.

This species is characterized by limbate leaves with acute elimbate tips, costae ending 1-4 cells below the apex to percurrent and dorsal laminae that towards the insertion run down the costa as a pluristratose, narrow, often limbidioid band
(Fig. 14: 10) that reaches the insertion or not. It is one of the few Fissidens species in which the limbidia of the dorsal lamina can be intramarginal (Fig. 14: 7). Like many rheophilous species it is often worn off and shows many irregularities (rheomorphoses). Limbidia can be lacking on the dorsal and apical lamina of upper and mid leaves even when leaves lower in the same stem have strongly limbate dorsal and apical lamina (typically limbidia of lower leaves are less well developed then those of higher leaves). The type specimen is particularly rich in rheomorphoses. For instance in some perichaetial and upper leaves the basal $2 / 3$ of the dorsal lamina is limbidioid, whereas in mid leaves the limbidia are sometimes confluent with costal branches (Fig. 14: 9; Demaret \& Potier de la Varde 1957, fig. 78A). Fissidens robynsianus differs from the rheophilous to hydrophilous $F$. leucocinctus by its narrower leaves that are not or hardly attenuated below and the frequent occurrence of rheomorphoses; from the rheophilous $F$. pachylomadelphus it differs by its elimbate leaf apices (in $F$. pachylomadelphus the limbidia are confluent with the costae into a mucronate apex). Fissidens curvatus, though not a rheophilous species, may occur in similar places. It differs by being heterocaulous and having limbate leaf apices.

ECOLOGY. Rheophilous and saxicolous. On wet, sprayed and irrigated rocks in and along rivers and near waterfalls.

Altitude. (1000) 2490-3870 m.

Distribution. Democratic Republic of the Congo (Rwenzori), Kenya, Tanzania (Arusha and Kilimanjaro), and Uganda. Rare. New to Tanzania,

SPECIMENS EXAMINED: TANZANIA, WSW slope of Mt. Meru, Kis \& Pócs 9145/S (EGR, L); S-Pare Mts, Pócs 6716/J mixed with $F$. obscurifrons (EGR, L). DEMOCRATIC REPUBLIC OF THE CONGO, Demaret

Fig. 13. Fissidens pachylomadelphus Demaret \& P. de la Varde 1 - vegetative stem; 2 - perigonium; 3-6 - leaves; 7-9 - leaf apices; 10 - mid leaf; $11 \& 12$ - basal parts of leaves; 13 - trans section of stem; 14 - trans section of costa and dorsal lamina near insertion; 1, 4, 9 \& 11 from Bryoptrop 6203 (private herbarium Bruggeman-Nannenga); 2, 3, 5, 7-8, 10, 12-14 from Kis \& Pócs 9136/N (L); and 6 from Kis \& Pócs 9129/BY (EGR) (red brown coloration in 4, 5, 9, 10 \& 12 is caused by 5\% KOH). 

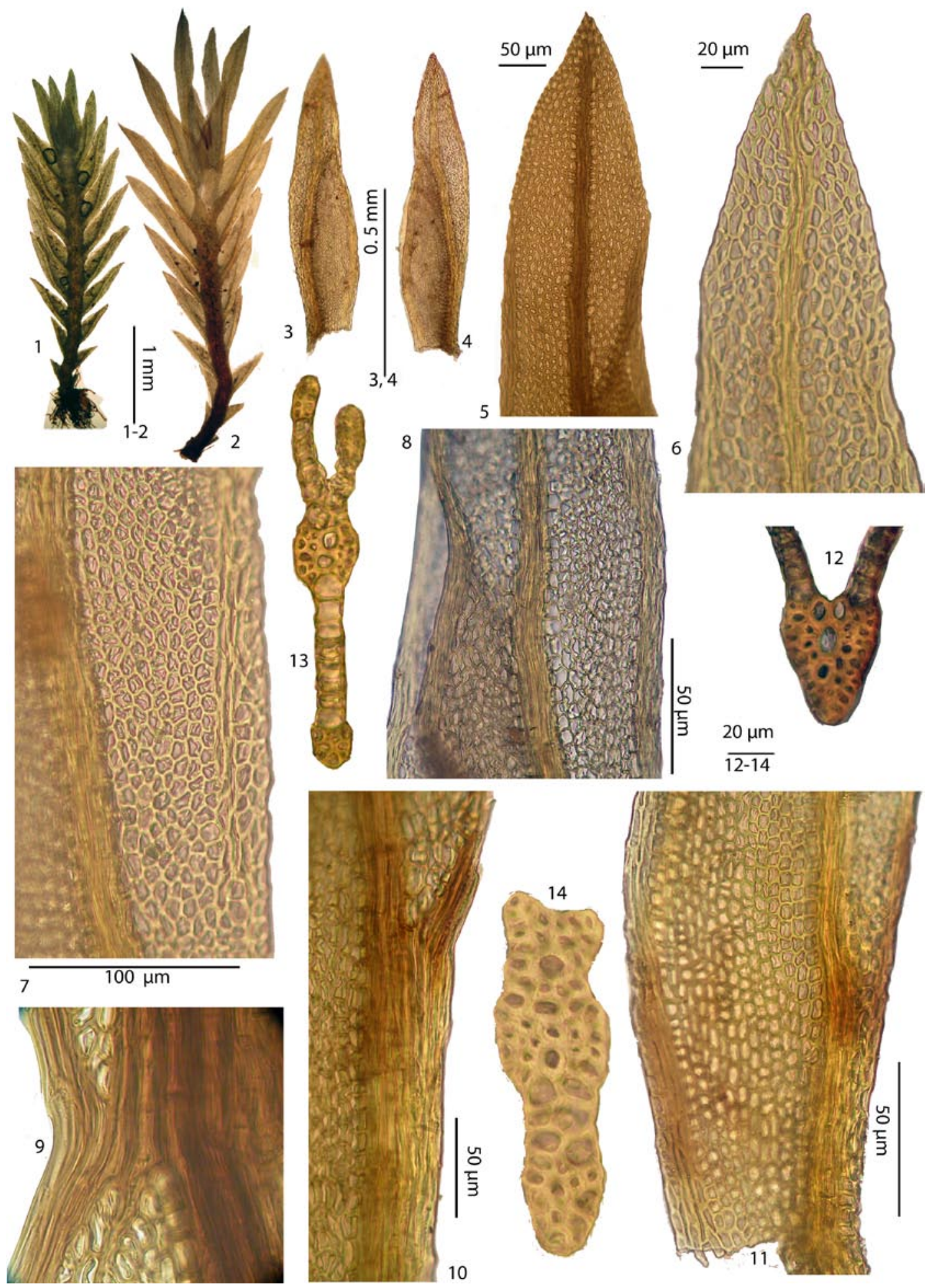
5257 (BR) and 5259 (BR). - KENYA, Pócs, Kungu, Szabo 9211/BN, BO, $A W$ (EGR, L). - UGANDA, Wesche 9107 (private herbarium Bruggeman-Nannenga).

Illustrations. Demaret \& Potier de la Varde (1957: fig. 78), Bruggeman-Nannenga (2006b: fig. 21, $\mathrm{g}-\mathrm{j})$.

\section{Fissidens rotereaui P. de la Varde Fig. 15}

Mém. Soc. Sci. Nat. Cherbourg 43: 63, fig. 1. 1938. HOLOTYPE: Madagascar, Manisana, sur la terre, 20 May 1906, Rotereau 9 (PC-PV).

Fissidens schelpei P. de la Varde, Rev. Bryol. Lichénol. 22: 10, fig. 3. 1953. - TYPE: Kenya, Marania river, Mt. Kenya (North sector). On moist earth bank in deep shade underneath grass tussocks, $9800 \mathrm{ft} .2$ VIII 1949. Schelpe 2538 (HOLOTYPE: PV-PC (3 stems); ISOTYPE: BM).

Growing scattered or in mats; stems weakly heterocaulous, with weak or lacking central strand, mostly unbranched, pinnate, 2.0-3.0 $\times$ 0.7-1.2 mm; rhizoids basal, brown, smooth; axillary nodules not to hardly differentiated; leaves green, distant, 10-14 pairs, slightly crispate when dry, lanceolate, acute to acuminate, often notched at the apex of the vaginant lamina, 0.65-0.90 $\times$ $0.20-0.25 \mathrm{~mm}, \mathrm{~L} / \mathrm{W} 3.0-3.5$, margin subentire, limbate on vaginant lamina; limbidium present on all leaves of both vegetative and fertile stems, typically restricted to the vaginant lamina (rarely few stems of a collection have weak limbidia on the mid dorsal lamina), extending the complete length of the vaginant laminae, less often shorter, often extending slightly onto the apical laminae, mostly not confluent at the apex of the vaginant lamina, reaching the insertion, limbidium cells firm walled, unistratose, marginal; vaginant lamina 3/5-7/10 the leaf length, half open to closed, unistratose; dorsal lamina slightly to distinctly rounded at the insertion, mostly reaching the insertion, not to slightly decurrent, dorsal and apical laminae unistratose; costa percurrent; mid dorsal laminal cells hexagonal, plane, smooth, firm-walled, 5.0-13.5 $\times$ $5.0-9.5 \mu \mathrm{m}$; mid vaginant laminal cells $8.0-13.0$ $\times 6.5-8.0 \mu \mathrm{m}$.

Fertile parts often lacking, perigonia not seen, perichaetia terminal on long to very short stems or long branches; perichaetial leaves $1.0-1.5 \mathrm{~mm}$ long, archegonia 220-350 $\mu \mathrm{m}$ long; sporophyte not seen.

Fissidens rotereaui is a rather constant species characterized by strong, unistratose limbidia that typically reach the complete length of the vaginant lamina and sometimes extend slightly onto the apical lamina; limbidia present on the vaginant laminae of all leaves of both vegetative and perichaetial stems; firm cell walls [limbidial (Fig. 15: 11) as well as laminal]; and percurrent costae. Its leaves are often notched just before the termination of the vaginant laminae (Fig. 15: 8). Like $F$. curvatus it can have (pseudo) papillae (Fig. 15: 10). It can be confused with other partly limbate species. Of these $F$. taylorii has vegetative stem leaves that are elimbate or weakly limbate on the basal part of the vaginant lamina and costae that $1-4$ cells below the apex. Moreover, the latter species is heterocaulous.

NOTE. In 1997 (Bruggeman-Nannenga 1997) I reduced with some hesitation $F$. rotereaui to $F$. bogosicus. Later, it became more and more clear that $F$. rotereaui is a distinct taxon (BruggemanNannenga in O'Shea et al. 2001; BruggemanNannenga \& Arts 2010). It is here reinstated as a species. Fissidens bogosicus differs in that limbidia are mostly restricted to the upper and mid leaves, and the costae are shorter.

HABITAT. In forests (montane rainforest $2 \times$, mesic montane rainforest, mossy montane evergreen, evergreen forest, bamboo forest), bushes (subalpine Erica-Hypericum bush) and roadside bank, Tanzania: Hagenia-Podocarpus forest.

Fig. 14. Fissidens robynsianus P. de la Varde 1 - vegetative stem; 2 - perichaetial stem; 3 \& 4 - leaves; 5 \& 6 - leaf apices; 7 - margin mid dorsal lamina with intramarginal limbidium; 8 - midleaf; 9 - rheomorphose, limbidium of apical lamina confluent with the costa in mid leaf, scale not available; 10 - basal part of leaf with limbidioid dorsal lamina; 11 - basal part of leaf; 12 - trans section of basal part of leaf; 13 \&14: trans sections of leaves near the termination of the vaginant lamina; $1 \& 14$ from Pócs, Kungu, Szabo 9211/AW (L); 2-4 \& 11 from Pócs 6716/J (L); 8, 10, 12 \&13 from Wesche 9107 (private herbarium Bruggeman-Nannenga); 5-7 from Kis \& Pócs 9145/S (L); 9 from holotype Demaret 5257 (BR). 

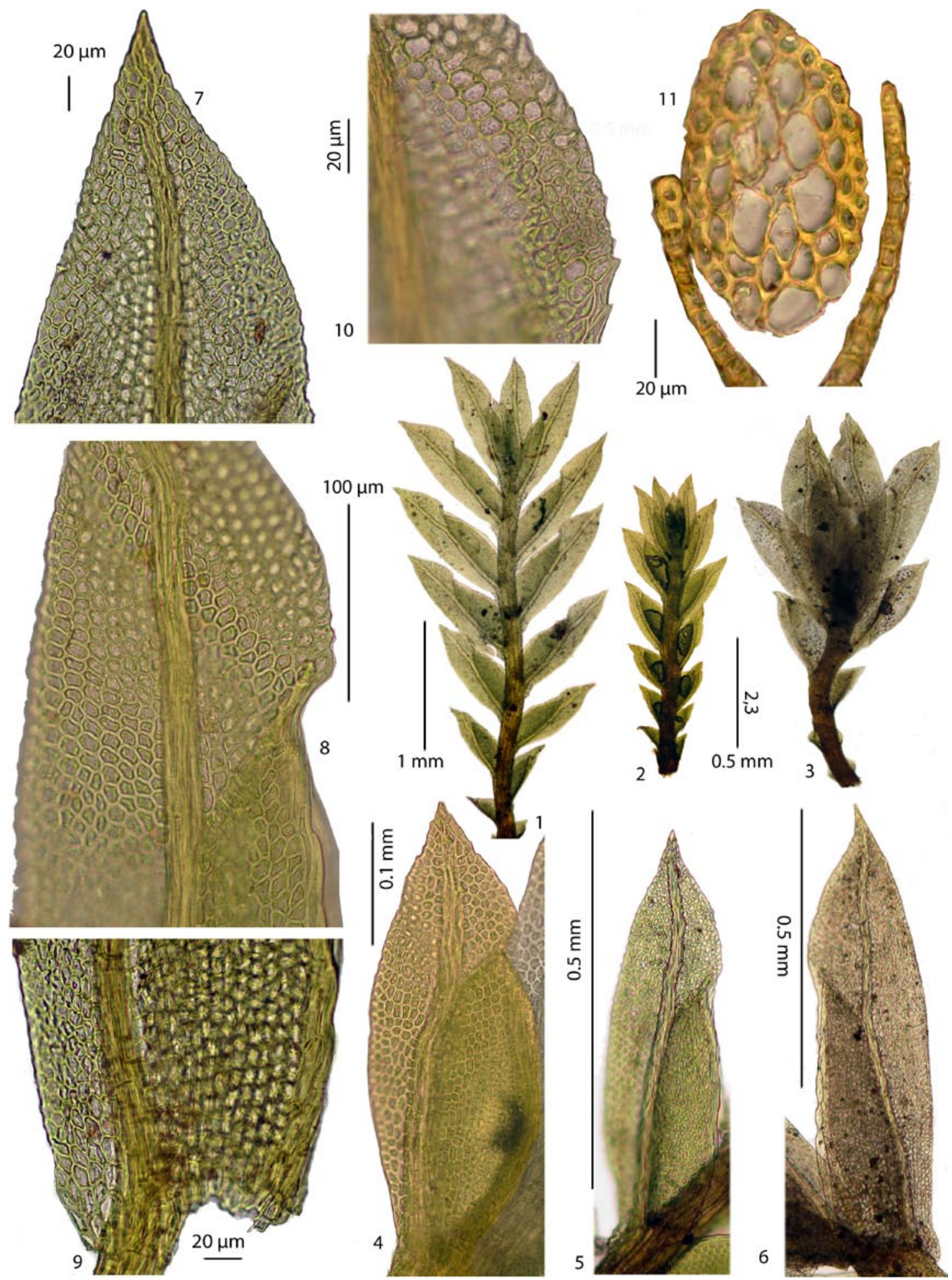
SUBSTRATE. Mostly on rocks, also on soil, rarely lignicolous; Tanzanian collections from soil.

\section{Altitude. 1340-2890 m.}

Distribution. East tropical Africa (Kenya, Tanzania); south tropical Africa (Malawi); and western Indian Ocean (Madagascar, La Réunion). New to Tanzania.

SPECIMENS EXAMINED: TANZANIA, Kilimanjaro, Kilimanjaro Mts, Pócs \& Ochyra 88122/BP, BQ (EGR, private herbarium Bruggeman-Nannenga); Morogoro, S Uluguru Mts, Van Zanten \& Pócs 86.08.665 (GRO a few stems only). - KENYA, S. Nyeri District, Mt. Kenya, Townsend 85/163 a few in mixture (E).MADGASCAR, Central Madagascar, Pócs 9481/DC (EGR, L). - MALAWI, Mulanje Mt, Wigginton $1257 a$ (E, private herbarium Bruggeman-Nannenga), Magombo $4297 A$ (E, private herbarium Bruggeman-Nannenga); Zomba, Pócs 9171/BD ( EGR, L). - LA RÉUNION, la Caverne de la Glacière, Arts 13/04 (BR, private herbarium Bruggeman-Nannenga); Forêt de Bébour, Bruggeman-Nannenga 11001 (L, REU) and Hellbourg, Müller $R 93$ and $R 621$ (both: DRE, private herbarium Bruggeman-Nannenga).

ILLUSTRATIONS: Bruggeman-Nannenga \& Arts (2010: fig. 13 as F. bogosicus); Potier de la Varde (1938: 63, fig.1; 1953: fig. 3 as F. schelpei).

\section{Fissidens rufescens Hornsch.}

Fig. 16

Linnaea 15: 153. 1841. - LECTOTYPE (designated by Bruggeman-Nannenga \& Pursell 1995): South Africa, Cape, Greenkloof, Breutel s.n. (BM).

Fissidens marginatus Schimp. ex Müll. Hal., Bot. Zeitung (Berlin) 16: 154. 1858. - HOLOTYPE: South Africa, Cape, Ecklon s.n. (BM).

Fissidens breutelii Schimp. ex Müll. Hal., Bot Zeitung (Berlin) 17: 198. 1859. - LECTOTYPE (designated by Magill 1981): South Africa, Cape, Gnadenthal, Kuhn s.n. (BM).

Note. Fissidens rufescens sensu Magill (1981) is Fis- sidens megalotis Schimp. ex Müll. Hal. subsp. megalotis (Bruggeman-Nannenga \& Pursell 1995).

Growing scattered or in loose tufts or mats; stem with central strand, mostly unbranched, $4.0-8.0 \times 0.7-1.8 \mathrm{~mm}$; rhizoids basal a few axillary, brown, faintly papillose; axillary nodules weakly differentiated; leaves green, mid and upper leaves close to distant, basal pairs distant, 5-12 pairs, crispate when dry often difficult to flatten, obscure, lanceolate to oblong-lanceolate, acute, broadly acute or obtuse, apiculate to mucronate, 0.6-2.0 × 0.2-0.5 mm, L/W 3-5; margin limbate; limbidium on all laminae of all leaves, reaching the leaf apex, confluent with the costa or ending just below; reaching the insertion of the vaginant lamina, limbidium of lesser lamella confluent with the costa; \pm reaching the insertion of the dorsal lamina not present on the decurrent part, on mid of dorsal lamina 7.5-16.0 $\mu \mathrm{m}$ wide, 1-2 stratose; on vaginant laminae $1-2$ stratose, marginal; vaginant lamina $1 / 2-2 / 3$ the leaf length, open, smaller lamella distally rounded to rounded truncate, unistratose sometimes bistratose alongside the costa; dorsal lamina, mostly tapering towards the insertion, straight to slightly rounded below, short to long decurrent, in the basal 5 leaf pairs ending far above the insertion, dorsal and apical laminae unistratose; costa per- to excurrent; mid dorsal laminal cells obscure, roundish- hexagonal to oblong with convex, thickened walls, 5-13 $\times$ 5-8 $\mu \mathrm{m}$; mid vaginant laminal cells clear, plane or convex, $8-21 \times 5-11 \mu \mathrm{m}$.

Fertile parts, perigonia (only one seen) terminal on short, $0.75 \mathrm{~mm}$ long, bud-like stems; antheridia $350 \mu \mathrm{m}$ long; perichaetial stems not markedly different from vegetative stems; perichaetia terminal, perichaetial leaves $1.8-2.7 \mathrm{~mm}$ long with rounded mucronate apex; archegonia 450 $500 \mu \mathrm{m}$ long. Sporophytes rare, not observed in Tanzanian material; seta 6-7 $\mathrm{mm}$ long, smooth;

Fig. 15. Fissidens rotereaui P. de la Varde $1 \& 2$ - vegetative stems; 3 - perichaetial stem; 4, 5 \& 6 - leaves; 7 - leaf apex; 8 - mid leaf; 9 - basal part of leaf; 10 - apical lamina with (pseudo?) papillae; 11 - trans section of stem and limbate margins of vaginant lamina; 1, 2, 4, 5 \& 8 from Bruggeman-Nannenga 11001 (private herbarium Bruggeman-Nannenga); 3 \& 10 from Arts RÉU 13/04 (private herbarium Bruggeman-Nannenga); 6, 7, 9, \& 11 from Pócs \& Ochyra 88122/BQ (private herbarium Bruggeman-Nannenga). 

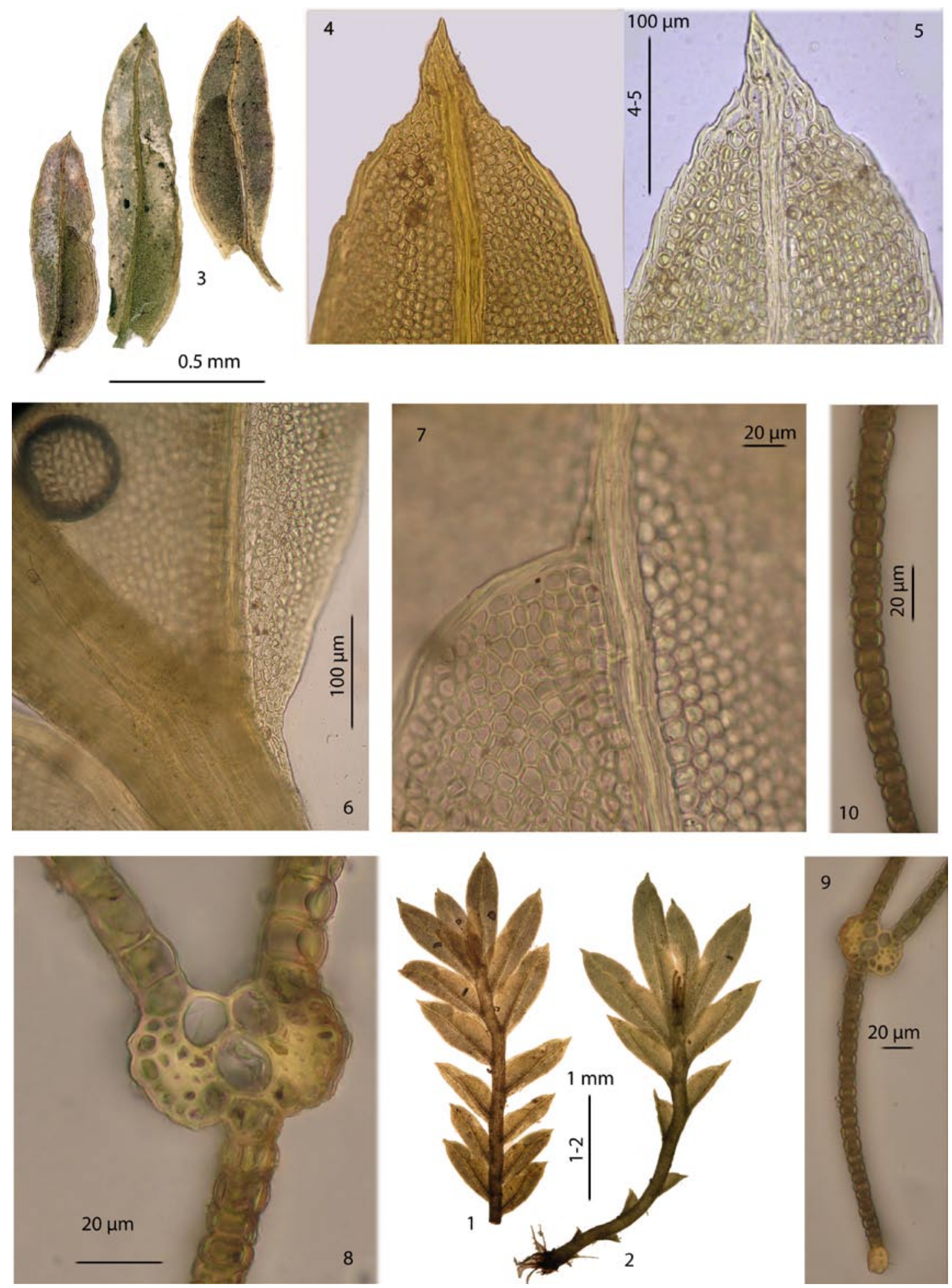
capsules inclined to curved to almost horizontal, $1.0-1.5 \times 0.4-0.9 \mathrm{~mm}$, with 50-60 files of oblong, exothecial cells; peristome bryoides type, teeth 49.5-54.5 $\mu \mathrm{m}$ wide at base; operculum not seen; calyptra not seen; spores 13.0-16.5 mm long, smooth to faintly papillose.

This species is easily recognized by its open vaginant laminae, obscure leaves with strongly convex dorsal and apical laminal cells, stout limbidia on all laminae and inclined to horizontal capsules. Fissidens beckettii also has open vaginant laminae and strongly inclined capsules, but has larger, not convex cells. Fissidens artsii and $F$. megalotis also often have convex, lenticularly thickened cell walls. Fissidens megalotis subsp. helictocaulos, however, has almost closed and Fissidens artsii completely closed vaginant laminae, whereas $F$. megalotis subsp. megalotis can be distinguished by its intramarginal limbidia.

HABITAT. In forests, stream sides, road banks, near cascades, in gardens and, less often, in grasslands.

SUBSTRATE. Mostly on soil, also saxicolous; in Tanzania on a lava cliff.

Altitude. 0-3540 m.

DisTRIBUTION. Northeast tropical Africa (Djibouti); east tropical Africa (Kenya, Tanzania); south tropical Africa (Malawi, Zimbabwe); southern Africa (Botswana, Lesotho, Namibia, South Africa); and western Indian Ocean (Madagascar, La Réunion). Rare in Tanzania.

SPECIMENS EXAMINED: TANZANIA, Mt. Kilimanjaro, Sharp et al. 7431/E (EGR, L). - MALAWI, Kungu $3237 y$ (E). - SOUTH AFRICA, Cape Province, Ecklon s.n. (BM); Lübenau SA 15R (private herbarium Bruggeman-Nannenga); Van Zanten 76.08 .43 (GRO) and 76.08.44 (GRO); Ecklon s.n. (BM).

ILLUSTRATIONS. Bruggeman-Nannenga \& Arts (2010: fig. 17), Magill (1981: fig. 10: 17-24 as F. marginatus).
18. Fissidens taylorii Müll. Hal.

Fig. 17

Syn. Musc. Frond. 1: 65. 1848. - TYPE: Australia, Swan River, J. Drummond s.n. (HOLOTYPE: FH; ISOLECTOTYPES: BM, FH) (not seen).

Growing scattered between other mosses. Stems heterocaulous, with central strand; rhizoids basal, pale brown to hyaline, smooth; axillary cells hardly differentiated; vegetative stems unbranched, pinnate, $1.10-2.00 \times 0.65-1.00 \mathrm{~mm}$; leaves pale green, distant, 5-12 pairs, hardly crispate (flexuose) when dry, elliptical to elliptico-lanceolate, acute, $0.37-1.40 \times 0.11-0.40 \mathrm{~mm}, \mathrm{~L} / \mathrm{W} 3-4$, margin subentire, elimbate, weak limbidium of a few thin-walled oblong cells on the basal part of vaginant laminae sometimes present; vaginant lamina $3 / 5-7 / 10$ the leaf length, slightly to half open, unistratose; dorsal lamina tapering and straight towards the insertion, reaching the insertion, not decurrent, dorsal and apical lamina unistratose; costa ending 1-5 cells below the leaf apex, bryoides type; mid dorsal laminal cells clear, hexagonal, smooth, plane, 9.0-16.0 ×6-11 $\mu \mathrm{m}$; mid vaginant laminal cells $8-18 \times 5-8 \mu \mathrm{m}$; vaginant laminal cells of perichaetial leaves often oblong, 24-35 $\mu \mathrm{m}$ long.

Fertile parts. Perigonia terminal, male stems 0.5-1.0 mm long, antheridia 170-200 $\mu \mathrm{m}$ long; perichaetial stems unbranched, $1.3 \times 1.0 \mathrm{~mm}$, frondiform; leaves crowded to slightly distant, 5-6 pairs that differ much in shape and size; upper and mid leaves of perichaetial stems limbate, limbidia present on all laminae or restricted to the vaginant laminae, extension variable, ending well below the leaf apex, reaching the insertion of the dorsal lamina or not, frequently restricted to (part of) the vaginant laminae, marginal or intramarginal, unistratose; perichaetia terminal; perichaetial leaves narrowly acute with percurrent costa, 1.1-1.5 mm long; archegonia $300 \mu \mathrm{m}$ long. Sporophyte, seta 3-4 mm long, smooth, 1 per perichaetium; capsule symmetrical, $0.55 \times 0.30 \mathrm{~mm}$,

Fig. 16. Fissidens rufescens Hornsch. 1 - vegetative stem; 2 - perichaetial stem; 3 - leaves; 4 \& 5 - leaf apices; 6 - leaf insertion; 7 - mid leaf; 8 - detail of 9; 9 - trans section leaf; 10 - trans section dorsal lamina showing the lenticularly thickened walls; 1, 2, 4 \& 6 from Van Zanten 76.08.44 (GRO); 3, 8-10 from Lübenau SA 123 (private herbarium Bruggeman-Nannenga); 5 \& 7 from Sharp et al. $7431 / E(\mathrm{~L})$. 

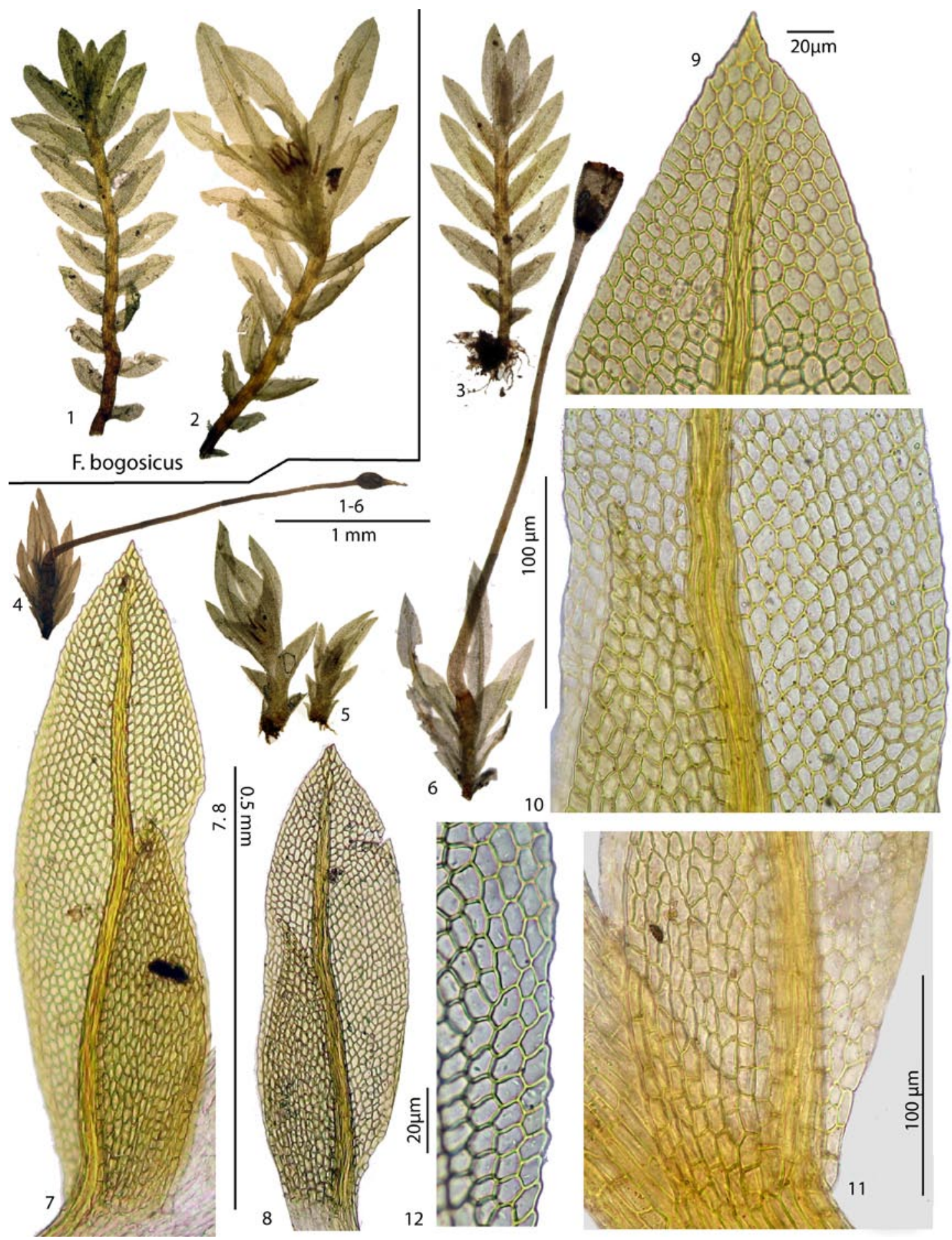
\pm 58 columns of oblong exothecial cells; peristome bryoides type, teeth $35-40 \mu \mathrm{m}$ wide at base; operculum not seen; calyptra mitrate, smooth, 0.45-0.50 mm long; spores 14-27 $\mu \mathrm{m}$ long, papillose.

This rare species is usually found in small quantities mixed with other species. It is characterized by heterocaulous stems, i.e., pinnate vegetative stems with characteristic elliptico-lanceolate leaves (Fig. 17: 3, 7, 8) and short, relatively large, frondose perichaetial stems; limbidia are typically restricted to the vaginant laminae of upper and mid leaves of perichaetial stems, but can be present on all laminae. It has costae that end 1-5 cells below the apex and bryoides type peristomes.

It is most likely to be confused with other partly limbate, heterocaulous species. Of these, $F$. pygmaeus Hornsch. (not known from Tanzania) can be distinguished by its completely open vaginant laminae and the typically recurved leaf apices on infertile stems. Fissidens bogosicus has similar vegetative stems, but is less distinctly heterocaulous. It has longer, pinnate perichaetial stems with distant leaves that except for the upper leaves do not differ from vegetative stems. The vegetative stems of these two species are compared in Fig. 17: 1 and 3, and the perichaetial stems in Fig. 17: 2 and 4-6. In vegetative state these species can not be separated with certainty. Fissidens rotereaui has limbate vaginant laminae on all or most leaves of both vegetative and perichaetial stems, firm limbidia that typically reach the apex of the vaginant laminae and percurrent costae. The leaves of the semiaquatic $F$. obscurifrons are obscure and attenuated towards the insertion (Fig. 12: 2-5); furthermore this species typically has limbate vaginant laminae on all leaves of both vegetative and perichaetial stems and limbidia that may extend up to $150 \mu \mathrm{m}$ onto the apical laminae. Fissidens curvatus is equally heterocaulous, but has limbidia on all laminae of all leaves that are confluent at the leaf apex and excurrent costae.

HABITAT. Insufficiently known: rainforest, montane rainforest, dry evergreen gulley forest.

SUBSTRATE. On stone and soil.

Altitude. 930-2400 m.

Distribution. Pantropical. USA, neotropics, Australia, New Zealand and St Helena. In Africa known from Tanzania (Arusha and Tanga) and Uganda. New to Africa.

SPECIMENS EXAMINED: TANZANIA, Arusha, Arusha National Park, Sharp 8871 (PC cited by Bizot et al., 1979 as $F$. stellenboschianus); Arusha region, S slope of Longido Hill, Pócs et al. 87165/AC p.p. mixed with several other Fissidens species (EGR, L); Tanga, East Usambara, Brago \& Vollesen s.n. (PC, cited by Bizot et al. 1978 as F. stellenboschianus). - UGANDA, Rukungiri, Bwindi NP, Hodgetts U 4596 A (E). - NEW ZEALAND, Wellington, Lyell's Bay, Roper s.n. (BM). - ST HELENA, Wigginton 05/287A and Wigginton 05/364A (both: E, private herbarium Bruggeman-Nannenga).

SELECTED ILLUSTRATIONS: Beever et al. (2002: 68), Pursell (1997: figs 1-7; 2007: 101, fig. 49D), Stone \& Beever (1996: fig. 1-2); Bruggeman-Nannenga \& Wigginton (2012: fig. 2: 3-7).

\section{EXCLUDED SPECIES}

Fissidens linearilimbatus Müll. Hal., Flora 73: 471. 1890. - TYPE: Afr. or. trop., Leikipia in regione occid. montis Kenia, inter Trichostomum Leikipiae m. vigens, L. Höhnel in Exped. Telekiana 1887. I have not been able to locate a type specimen.

Fissidens menyharti Müll. Hal., Hedwigia 38: 54. 1899 - TYPE: Ad flumen Zambesi medium circa Borome, Dec. 1890, Menyhárt, HB. Vindebonense mis. 1893 (=?F. androgynus fide Sim 1926: 199). Sim did not see the type specimen. I too have been unable to locate a type.

Fig. 17. Fissidens bogosicus Müll. Hal. (1 \& 2). 1 - vegetative stem; 2 - archegonial stem. Fissidens taylorii Müll. Hal. (3-12). 3 - vegetative stem; 5 - archegonial stems; 4 \& 6 - sporophytic stems; $7 \& 8$ - leaves; 9 - leaf apex; 10 - mid leaf; 11 - basal part of leaf; 12 - mid margin dorsal lamina; 1 \& 2 from Pócs \& Magombo 9176/O (L); 3, 6, 8-11 from Pócs et al. 87165/ AC (L); 4 from Brago \& Vollesen s.n. (PC), 5 \&12 from Hodgetts U4596A (private herbarium Bruggeman-Nannenga); 7 from Pócs $8663 / N(\mathrm{~L})$. 
ACKNOWLEDGEMENTS. I am grateful to the curators of BM, BR, EGR, H, K, L, MO, NY, PC and PRE for the loan of specimens, to Nicolien Sol and Gerard Thijsse (L) for practical support, Iris and Henk Wevers for help with organizing the geographical date, and to Dr. Ron Pursell and Dr. Jessica Beever for helpful comments.

\section{REFERENCES}

ARTS T. 1998. A contribution to the moss flora of the Cape Provinces (South Africa). J. Bryol. 20: 429-447.

Beever J. E., Malcolm B. \& Malcolm N. 2002. The moss genus Fissidens in New Zealand an illustrated key. MicroOptics Press. Nelson N.Z.

Bizot M., 1963. Nanobryum gladiolum (Mitt.) Biz. comb. nov. Rev. Bryol. Lichénol. 32: 82-83.

Bizot M. \& Pócs T. 1979. East African bryophytes III. Acta Bot. Acad. Sci. Hung. 25: 223-261.

Bizot M., Dury M. N. \& Pócs T. 1976, East African Bryophytes, II. Collections made by L. Ryvarden in Malawi, SE Africa. Acta Bot. Acad. Sci. Hung. 22(1-2): 1-8.

Bizot M., Pócs T. \& Sharp A. J. 1979. Results of a bryogeographical expedition to east Africa in 1968. II. J. Hattori Bot. Lab. 45: 145-165.

Bizot M., FriIs I., Lewinsky J. \& Pócs T. 1978. East African bryophytes IV. Danish collections. Lindbergia 4: 259-284.

BRUGGEMAN-NANNENGA M. A. 1993. Taxonomic Results of the BRYOTROP expedition to Rwanda and Zaire. 15. Fissidentaceae. Trop. Bryol. 8: 141-148.

BRUgGeman-NANNEnga M. A. 1997. Notes on Fissidens VI. New synonyms, new combinations and validation of some names. J. Hattori Bot. Lab. 81: 155-173.

Bruggeman-Nannenga M. A. 1999. Notes on Seychelles mosses. 2 A revision of Fissidentaceae. Bryobrothera $\mathbf{5}$ : $65-75$.

Bruggeman-NAnNEnga M. A. 2005. Two new species of Fissidens (Fissidentaceae, Musci) from Africa, Fissidens harringtonii and Fissidens artsii. Trop. Bryol. 26: 13-17.

BRUGGEMAN-NANNENGA M. A. 2006a. Bryophyte flora of Uganda. 6. Fissidentaceae (Part 1). J. Bryol. 28: 53-62.

Bruggeman-NAnNEnga M. A. 2006b. Bryophyte Flora of Uganda 6 Fissidentaceae (Part 2). J. Bryol. 28: 139-148.

BRUGGEMAN-NANNENGA M. A. 2009. Notes on Fissidens VIIIX. J. Bryol. 31: 106-116.

BRUGGEMAN-NANNENGA M. A. 2013a. Fissidens tamaspocsii and $F$. magnicellulatus spp. nov. from eastern Africa and validation of $F$. cyatheicola. Lindbergia 36: 9-14.

Bruggeman-Nannenga M. A. 2013b. Two new Fissidens species (Fissidentaceae) from tropical eastern Africa and
Fissidens bessouensis Corb., a remarkable species with fimbriate leaves and multicellular spores. Polish Bot. J. 58(1): 117-125.

Bruggeman-NANNENGa M. A. \& ARTS T. 2010. A revision of the Fissidentaceae (Musci) of La Réunion (including all species known from Mauritius and Rodriguez). J. Bryol. 32: 170-207.

Bruggeman-Nannenga M. A. \& Pursell R. A. 1995. Notes on Fissidens V. Lindbergia 20: 49-55.

BRuggeman-NANNENGa M. A. \& Wigginton M. J. 2012. Bryophytes of St Helena, South Atlantic Ocean. 5. Fissidens Lindb. (Fissidentaceae), including a description of $F$. translucens sp. nov. and Fissidens curvatus Hornsch. subsp. sanctae-helenae subsp. nov. J. Bryol. 34: 212-230.

Chuah-Petiot M. S. 2003. Mosses, liverworts and hornworts of Kenya. An illustrated guide with descriptions and figures of over 300 species and keys for identification. ChuahPetiot, Nairobi.

Demaret F. \& Leroy V. 1944. Exploration du Parc National Albert. Mission J. Lebrun (1937-1938) fascicule 6. Mousses: 1-65. Imprimerie M. Hayez, Brussels.

Demaret F. \& Potier De La VArde R. 1957. Trois Fissidens et un Philonotis nouveaux du Ruwenzori. Bull. Jard. Bot. État Bruxelles 27: 755-762.

DiXON H. N.1922. Some new genera of mosses. J. Bot. 60: 101-110, pl. 564.

IWATSUKi Z. \& Pursell R. A. 1980. Axillary nodules in Fissidens (Fissidentaceae). J. Hattori Bot. Lab. 48: 329-335.

IWATSUKI Z. \& SUZUKI T. 1982. A taxonomic revision of the Japanese species of Fissidens (Musci). J. Hattori Bot. Lab. 51: 329-508.

KIS G. 1985. Mosses of South-East Tropical Africa. Vácrátót, Hungary.

KÜRSCHNER H. 1999. New moss records for Socotra and Yemen mainland. Studies in Arabian bryophytes 24. Nova Hedwigia 69: 399-405.

Magill R. E. 1981. Bryophyta. Part 1. Mosses. Fascicle I. Sphagnaceae - Grimmiaceae In: O. A. LEISTNER (ed.), Flora of Southern Africa.. Botanical research Institute, Department of Agriculture and Fisheries, Republic of South Africa.

MÜLLER C. 1900. Genera Muscorum Frondosorum. E. Kummer. Leipzig.

O'SHEA B. J. 2006. Checklist of the mosses of sub-Saharan Africa (version 5, 12/06). Tropical Bryology Research Reports 6: 1-152.

O’Shea B. J.,Wigginton M. J., BRUgGeman-NANNEnga M. A., Hodgetts N. G. \& Porley R. D. 2001. British Bryological Society Expedition to Mulanje Mountain, Malawi. 13. New and other unpublished records. Trop. Bryol. 20: 1-26. 
O’Shea B. J., Wigginton M. J, Bruggeman-Nannenga M. A., HedenÄs L., Matcham H. W., Frahm J.-P., PorLey R. D., Ellis L. T., Watling M. C., Bates, J. E. \& VÁŇ́A J. 2003. Bryophytes of Uganda, 6. New and additional records, 3. Trop. Bryol. 24: 161-168.

Potier DE LA VARDE R. 1926. Mousses nouvelles de l'Afrique tropicale française. Quatrième note. Bull. Soc. Bot. France 73: $377-386$.

Potier de la Varde R. 1928. Mousses de l'Oubangui. Arch. Bot. Mém. 3: 1-152, pl. 1-4.

PotiER DE LA VARDE R. 1929. Etudes préliminaires de quelques espèces africaines du genre Fissidens. Ann. Cryptog. Exot. 2: 272-290.

Potier DE LA VARDE R. 1932, Récoltes bryologiques aux environs de Bozoum. Rev. Bryol. Lichénol. 5: 83-90.

Potier DE LA VARdE R. 1936. Herborisations dans la région de Bocaranga (Oubangui). Rev. Bryol. Lichénol. 9: 194-209.

Potier DE LA VARde R. 1938. Sur une collection de Mousses malgaches. Mémoires de la Société Nationale des Sciences Naturelles et Mathématiques de Cherbourg 43: 63-69.

POTIER DE LA VARDE R. 1943. Mousses nouvelles recoltées aux Iles du Cap Verts par. M. Aug. Chevalier en 1934. Bull. Mus. Hist. Nat. (Paris) 15: 239-243.

Potier DE LA VARDE R. 1953. Contribution à la flore bryologique africaine (cinquième article). Rev. Bryol. Lichénol. 22: 6-15.
Pursell R. A. 1994. Fissidentales. In: A. J. SHARP, H. CRUM \& P. M. ECKEL (eds), The Moss Flora of Mexico. Part one. The New York Botanical Garden, New York.

PURSELl R. A. 1997 [1998]. Fissidens taylorii, new to North America north of Mexico. Bryologist 100: 525-528.

PURSELl R. A. 2007. Fissidentaceae. Flora Neotropica Monograph 101. The New York Botanical Garden Press, New York.

Pursell R. A. \& Bruggeman-NAnNenga M. A. 2004. A revison of the infrageneric taxa of Fissidens. Bryologist 107: $1-20$.

PuRSELl R. A. \& REESE W. D. 1980. The taxonomic status of the Nanobryaceae (Bryopsida). Bryologist 83: 559-562.

RENAULD F. 1909. Essai sur les Leucoloma et Supplément au Prodrome de la Flore Bryologique de Madagascar, des Mascareignes et des Comores. Monaco.

Shevock J., Pursell R. A., Garcia C., Bruggeman-NaNNENGA M. A. \& SÉRgIO C. 2013. The genus Fissidens in the Republic of São Tomé and Príncipe, Gulf of Guinea, West Africa. J. Bryol. 35: 197-205.

Smith A. J. E. 1978. The Moss Flora of Britain and Ireland. Cambridge University Press, Cambridge.

Stone I. G. \& BeEver J. E. 1996. Studies of the Australian moss Fissidens taylorii C. Muell. J. Bryol. 19: 49-64.

TongIORgI E. 1938. Schaedulae bryologicae Africae orientalis Italicae. 1. Fissidens badoglioi n. sp. Nuovo Giorn. Bot. Ital. 45: 219-220. 